\title{
WPROWADZENIE DO FILOZOFII MATEMATYKI
}




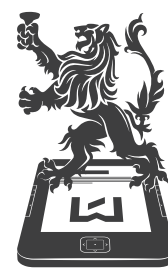

WYDAWNICTWO

UNIIERSYTETU
EODZKIEGO 


\section{ADAM NOWACZYK}

\section{WPROWADZENIE \\ DO FILOZOFII \\ MATEMATYKI}


Adam Nowaczyk - Uniwersytet Łódzki, Wydział Filozoficzno-Historyczny, Instytut Filozofii Katedra Logiki i Metodologii Nauk, 90-131 Łódź, ul. Lindleya 3/5

\author{
RECENZENT \\ Mieczystaw Omyta \\ REDAKTOR INICJUJACY \\ Magdalena Skoneczna \\ WERYFIKACJA TEKSTU DRUGIEGO WYDANIA \\ Marek Nowak \\ SKŁAD I ŁAMANIE \\ Kamil Pajek \\ KOREKTA \\ Pawet M. Sobczak \\ KOREKTA TECHNICZNA \\ Leonora Gralka \\ PROJEKT OKŁADKI \\ Katarzyna Turkowska
}

Zdjęcie wykorzystane na okładce: ( Depositphotos.com/Vanzyst

(C) Copyright by Adam Nowaczyk, Łódź 2019

(C) Copyright for this edition by Uniwersytet Łódzki, Łódź 2019

Wydane przez Wydawnictwo Uniwersytetu Łódzkiego

Wydanie II. W.09307.19.0.M

Ark. druk. 5,5

e-ISBN 978-83-8142-702-9

Wydawnictwo Uniwersytetu Łódzkiego

90-131 Łódź, ul. Lindleya 8

www.wydawnictwo.uni.lodz.pl

e-mail: ksiegarnia@uni.lodz.pl

tel. (42) 6655863 


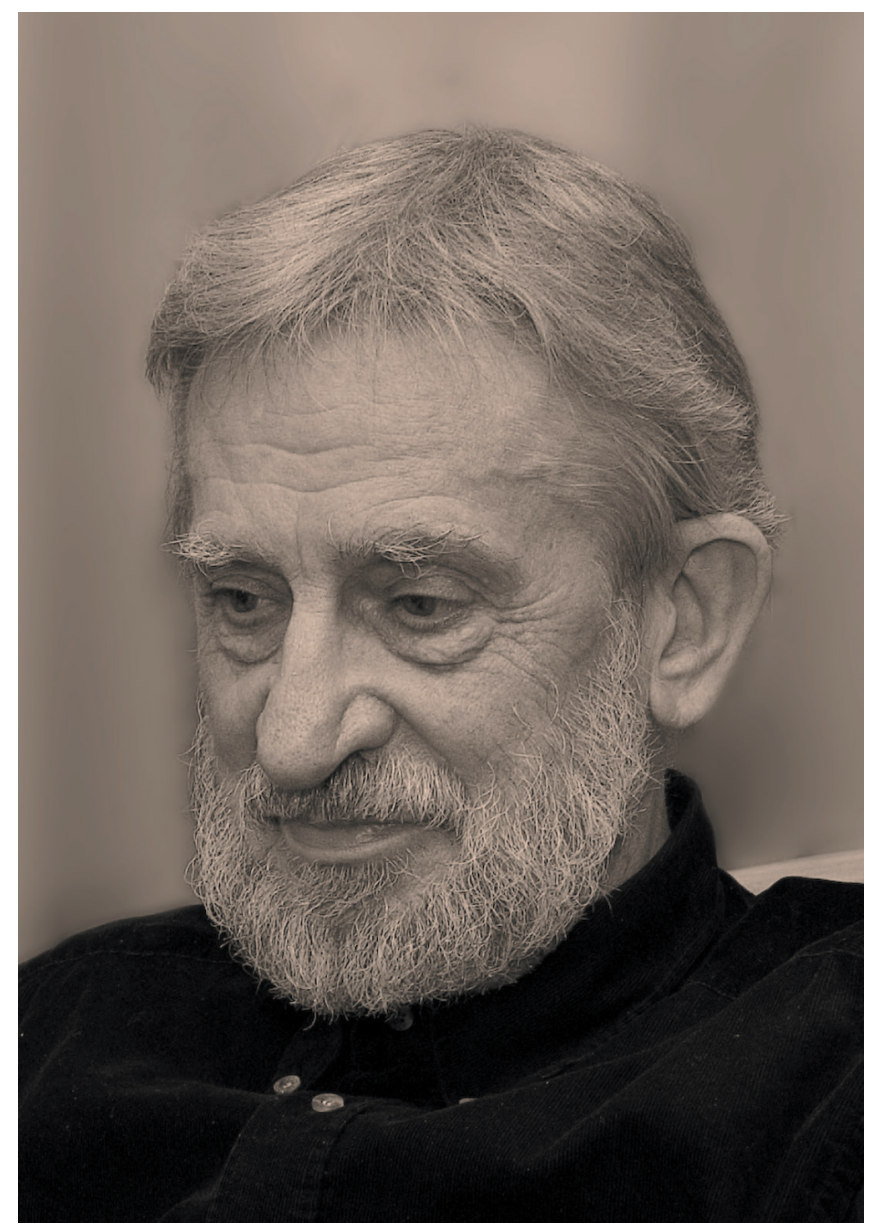

Adam Nowaczyk 



\section{SPIS TREŚCI}

Przedmowa ......................... 7

Wykład pierwszy. Filozofia, nauka, filozofia nauki. . . . . . . . . . . . . 9

Wykład drugi. Jak podzielić naukę? . . . . . . . . . . . . . . . . . . . 15

Wykład trzeci. Co istnieje?. . . . . . . . . . . . . . . . . . . . . 21

Wykład czwarty. Czym są teorie naukowe? . . . . . . . . . . . . . . . . 27

Wykład piąty. Języki i teorie sformalizowane. . . . . . . . . . . . . . . 33

Wykład szósty. Wyprowadzalność a wynikanie logiczne . . . . . . . . . . . . 41

Wykład siódmy. Prawda . . . . . . . . . . . . . . . . . . . . . . . 47

Wykład ósmy. Języki elementarne i ich interpretacje . . . . . . . . . . . . 53

Wykład dziewiąty. Teorie elementarne i nieelementarne . . . . . . . . . . . . 59

Wykład dziesiąty. Ograniczenia formalizacji . . . . . . . . . . . . . . 63

Wykład jedenasty. Spór o przedmiot matematyki . . . . . . . . . . . . . . 67

Wykład dwunasty. Spór o naturę poznania matematycznego . . . . . . . . . . . 75

Wykład trzynasty. Nauki ścisłe, czyli matematyka stosowana . . . . . . . . . . 83 



\section{PRZEDMOWA}

Treść tej niedużej książki pokrywa się w zasadzie z treścią wykładów, które od kilku lat prowadzę dla doktorantów Wydziału Matematyki Uniwersytetu Łódzkiego, wybierających w swoim przewodzie doktorskim jako dodatkowy, egzamin z filozofii. Nie są to wykłady z filozofii matematyki w pełnym tego słowa znaczeniu. Zgodnie z tytułem, stanowią one właśnie rodzaj takiego wprowadzenia do filozofii matematyki, które mogłoby ułatwić lekturę pozycji obszerniejszych, poważniejszych i źródłowych.

Dwa pierwsze wykłady mają charakter zdecydowanie ogólny. W pierwszym usiłowałem objaśnić, czym jest współcześnie filozofia, jakie miejsce zajmuje w niej refleksja nad nauką i jakie są jej odmiany; w drugim starałem się usytuować matematykę w konstelacji ogółu dyscyplin naukowych mając na względzie ich zróżnicowanie pod różnymi względami istotnymi z filozoficznego punktu widzenia. Wykład trzeci wprowadza w problematykę ontologii, istotną w kontekście dyskusji nad przedmiotem matematyki. Z uwagi na to, że jako cel dociekań naukowych wskazuje się zazwyczaj zbudowanie teorii, wykład czwarty poświęciłem pojęciu teorii. Pokazuję w nim, że to, co się faktycznie określa mianem teorii w matematyce i w naukach ścisłych w istotny sposób odbiega od pojęcia teorii jako systemu aksjomatyczno-dedukcyjnego.

Kolejne wykłady, od piątego do dziewiątego, traktują o pojęciach, procedurach i twierdzeniach, które zazwyczaj są przedmiotem dyscyplin określanych mianem logiki formalnej, metalogiki bądź metamatematyki. Znalazły się one tutaj ze względu na to, że nie wszyscy studenci i absolwenci matematyki, do których ta książka jest adresowana, dysponują wystarczającym zasobem wiadomości z tych dziedzin, a bez nich problemy współczesnej filozofii matematyki pozostałyby niezrozumiałe. Ta część wykładów ma zatem charakter wyraźnie propedeutyczny, a przy tym elementarny.

Wykład dziesiąty informuje o tzw. twierdzeniach limitacyjnych, za sprawą których zawiodły pewne oczekiwania związane z formalizacją rozumowań matematycznych i zmienił się obraz matematyki jako tzw. nauki formalnej.

Wykłady jedenasty i dwunasty traktują o dwóch centralnych problemach współczesnej filozofii matematyki i zarazem odwiecznych problemach filozoficznych. Są to pytania o przedmiot matematyki i swoistość poznania matematycznego. W wykładzie trzynastym (ostatnim) podejmuję problem, na czym polega korzystanie z matematyki w ,naukach realnych", a przede wszystkim w fizyce. 
Pod pewnym względem treść tej książki jest niejednorodna. W wykładach, gdzie dominuje problematyka formalno-logiczna i metamatematyczna, przedstawiam pojęcia i twierdzenia uznane za bezsporne. Nie jest to możliwe w wykładach, w których przeważa problematyka stricte filozoficzna. Mamy wówczas do czynienia z zagadnieniami, które nie doczekały się (i zapewne nigdy nie doczekają) ostatecznych i niepodważalnych rozstrzygnięć. W tym wypadku nie stronię od ujawniania własnego, z natury rzeczy kontrowersyjnego, stanowiska.

Książka ta nie pretenduje do roli monografii z dziedziny filozofii matematyki. Problemy tej dyscypliny filozoficznej zostały tu potraktowane wybiórczo i ujęte w sposób elementarny. Ponieważ starałem się, aby treść książki była dostępna nie tylko dla matematyków, lecz również dla filozofów, Czytelnik — zależnie od tego, czy jest matematykiem, czy filozofem - może te lub owe wyjaśnienia uznać za zbędne.

Czytelnikowi, którego ta książka skłoni do zapoznania się z aktualnym stanem filozoficznej refleksji nad matematyką zalecam, w pierwszej kolejności, lekturę antologii zredagowanej przez Romana Murawskiego, zatytułowanej Wspótczesna filozofia matematyki (Wydawnictwo Naukowe PWN, Warszawa 2002). Znajdzie tu kilkanaście pozycji światowego piśmiennictwa z tej dziedziny opatrzonych komentarzem i obszerną bibliografią.

Tym, którego dokonania najsilniej wpłynęły na aktualny obraz matematyki jako nauki formalnej, był niewątpliwie Kurt Gödel. Toteż jego poglądy filozoficzne i filozoficzne implikacje jego twierdzeń budzą duże zainteresowanie zarówno matematyków, jak i filozofów. Zainteresowanym stanowiskiem filozoficznym Gödla i wpływem, jaki jego odkrycia wywarły na filozofię (nie tylko filozofię matematyki) polecam dwie monografie: Krzysztofa Wójtowicza, Platonizm matematyczny. Studium filozofii Kurta Gödla (Seria Rozprawy OBI, Wydawnictwo Biblos, Tarnów 2002) oraz Stanisława Krajewskiego, Twierdzenie Gödla i jego interpretacje filozoficzne. Od mechanicyzmu do postmodernizmu (Wydawnictwo IFiS PAN, Warszawa 2003).

Łódź, czerwiec 2003 roku

Adam Nowaczyk 


\section{Wykład pierwszy}

\section{FILOZOFIA, NAUKA, FILOZOFIA NAUKI}

Filozofia jest szacowną dyscypliną wykładaną i uprawianą od wieków na uniwersytetach, ale nie jest nauką. Świadczą o tym pojawiające się od czasu do czasu hasła ,unaukowienia filozofii”. Natomiast pozostaje ona z nauką w rozmaitych związkach.

Po pierwsze, filozofia europejska ${ }^{1}$ i prawie wszystkie dziedziny nauki mają wspólny początek i wyrosły z tej samej ludzkiej potrzeby objaśniania i rozumienia otaczającego nas świata ${ }^{2}$. Na przestrzeni wieków poszczególne dyscypliny naukowe wyodrębniły się z filozofii, uzyskując samodzielność, często pod hasłem przeciwstawiania się „,filozoficznym spekulacjom”. Stosunkowo wcześnie oddzieliły się od filozofii nauki przyrodnicze, takie jak fizyka i chemia, aczkolwiek warto zauważyć, że dzieła Newtona i Daltona ${ }^{3}$, które stworzyły podstawy tych nauk miały jeszcze w tytule słowo filozofia. Ów proces emancypacji różnego rodzaju dociekań od filozofii trwa nadal, zwłaszcza w dziedzinie nauk humanistycznych.

Po drugie, mimo pewnych prób radykalnego odseparowania filozofii od nauki (podejmowanych - co ciekawe - głównie przez filozofów o krytycznym nastawieniu do filozofii) związki filozofii z naukami trwają, a ich wyrazem są tzw. filozoficzne zagadnienia danej dyscypliny (np. fizyki, biologii, językoznawstwa itp.). Te filozoficzne zagadnienia związane są na ogół bądź z przedmiotem danej dyscypliny, bądź z charakterem jej aparatu pojęciowego, natomiast nie dają się wyrazić w jej specjalistycznym języku; przeciwnie - formułowane są za pomocą tradycyjnych pojęć filozoficznych. Przykładem filozoficznego zagadnienia fizyki może być szeroko dyskutowany (zwłaszcza w latach pięćdziesiątych XX w.) problem deterministycznego względnie indeterministycznego charakteru praw fizyki. Pojęcie determinizmu (podobnie jak kojarzone z nim pojęcie

${ }^{1}$ Filozofie krajów pozaeuropejskich mają odmienny charakter, z czym zapewne wiąże się zdumiewający fakt, że nauki przyrodnicze, a zwłaszcza tzw. nauki ścisłe, są produktem europejskim, który inne kultury z Europy importowały.

2 Prawie wszystkie, bowiem nie dotyczy to arytmetyki i geometrii, których początki związane były w większym stopniu z zaspokojeniem potrzeb praktycznych. Uwaga ta dotyczy również astronomii, natomiast nie odnosi się do kosmologii.

${ }^{3}$ I. N e w t o n, Philosophiae naturalis principia mathematica (1687); J. D a 1 t o n, A New System of Chemical Philosophy (1808). 
przyczyny) jest pojęciem filozoficznym i nie daje się zdefiniować za pomocą pojęć żadnej teorii fizycznej.

Po trzecie, filozofię z nauką wiążą liczne unie personalne. Arystoteles (384-322 p.n.e.), jeden z najwybitniejszych filozofów starożytnych, prowadził, między innymi, staranne obserwacje i dociekania w dziedzinie biologii. Filozofowie Kartezjusz (1596-1650) i Leibniz (1646-1716) wnieśli istotny wkład do matematyki, a Pascal (1623-1662) również do fizyki. Fizyk Ernst Mach (1838-1916) jest twórcą oryginalnej filozofii zwanej empiriokrytycyzmem lub „drugim pozytywizmem”. Również wielu uczonych współczesnych ma w swoim dorobku publikacje filozoficzne, na ogół związane z zagadnieniami filozoficznymi swojej dyscypliny.

Po czwarte, domeną filozofii jest filozoficzna refleksja nad nauka rozumianą bądź jako profesjonalna działalność uczonych, bądź jako produkt tej działalności. Refleksja taka przybrała współcześnie kształt wyodrębnionej specjalności filozoficznej pod nazwą filozofii nauki. Użycie tu słowa refleksja z przymiotnikiem filozoficzna wymaga wyjaśnienia. Otóż słowo refleksja — zgodnie ze słownikowym znaczeniem przymiotnika „refleksyjny” - zwraca uwagę na zwrotny charakter dociekań (przedmiotem poznania jest tu właśnie poznanie, mianowicie poznanie naukowe), natomiast przymiotnik „filozoficzna" jest tu niezbędny z uwagi na to, że w ostatnich czasach powstało wiele dyscyplin naukoznawczych, których związek z filozofią jest mniej lub bardziej luźny.

Należałoby tu wymienić przede wszystkim historię nauki, której zadaniem jest rekonstrukcja dziejów nauki od jej początków do współczesności. Zadania tego nie można oddzielić od prób zrozumienia przemian w nauce, czyli od poszukiwania odpowiedzi na pytania typu „dlaczego?”. Pytania takie nie pozwalają abstrahować od pewnych założeń filozoficznych, co sprawia, że badania historyczne mają istotne znaczenie dla filozofii nauki. Znaczenie to polega głównie na tym, że historia nauki dostarcza dociekaniom filozoficznym materiału faktograficznego, z którym pomysły filozofów mogą być konfrontowane.

Inną dyscypliną naukoznawczą jest socjologia nauki uprawiana często jako dział socjologii wiedzy - dyscypliny traktującej o społecznych uwarunkowaniach kształtowania się przekonań (m.in. tych, które składają się na wiedzę naukową). Socjologowie nauki zmierzają niekiedy do wyeliminowania i zastąpienia filozofii nauki socjologią, co wiąże się z zakwestionowaniem całej tradycyjnej problematyki filozoficznej, a w szczególności zagadnień dotyczących prawdziwości i zasadności (uzasadnienia, wiarygodności) wiedzy naukowej.

Instytucjonalny charakter nauki współczesnej, a zwłaszcza daleko idące jej „upaństwowienie" sprawiają, że przedmiotem badań stają się również sprawy polityki naukowej oraz ekonomiki nauki. Nie wchodzą one w zakres filozofii nauki, aczkolwiek w pewien sposób o nią zahaczają, ponieważ wiążą się z wartościowaniem celów, którym badania naukowe mają służyć. 
Filozofia nauki jest obecnie jednym z intensywnie uprawianych działów filozofii. Jej przedmiotem jest nauka w swych różnych odmianach historycznych i teraźniejszych. Czytelnik nie będący filozofem, a mający — jak wielu współczesnych — dobre zdanie o nauce ma oczywiście prawo zapytać, dlaczego mają o niej wypowiadać się filozofowie, skoro — jak wiadomo - sama filozofia nauką nie jest. Czy zatem nie byłoby lepiej powierzyć to zajęcie uczonym, a więc matematykom, fizykom, biologom itp., ponieważ to oni wiedzą, czym jest nauka, skoro się nią parają?

Otóż uczeni często wypowiadają się o nauce (na ogół o swojej specjalności lub dziedzinach pokrewnych), ale właśnie w tym momencie przestają być uczonymi, a stają się lepszymi lub gorszymi filozofami, czyli wchodzq w innq rolę. Ta nowa rola wymaga przygotowania, polegającego na znajomości pewnej tradycji i pewnej już wypracowanej aparatury pojęciowej. Zdarza się oczywiście, że uczony, który zaczyna filozofować na temat nauki, staje się profesjonalnym filozofem.

Czy role uczonego i filozofa różnią się zasadniczo? Na pytanie to niełatwo odpowiedzieć, ponieważ odpowiedź zależy od tego, co obejmiemy określeniem filozofia, a w tej sprawie sami filozofowie nie potrafią dojść do porozumienia. Dlaczego tak się dzieje? Warto się nad tym zastanowić i w ten sposób uzyskać pewien obraz filozofii jako takiej, a nie tylko filozofii nauki.

Szczególne kłopoty związane z pytaniem, czym jest filozofia, biorą się stąd, że przedmiot jej zainteresowań był od początku zróżnicowany i niedający się objąć wspólną charakterystyką. Zgodnie z wiekową tradycją przedmiotem filozofii była zarówno rzeczywistość (rozumiana jako wszystko, co istnieje), jak również poznawanie tej rzeczywistości oraz jej wartościowanie (tj. jej ocenianie z różnych, ludzkich i ponadludzkich punktów widzenia). Jak już zauważyliśmy, z biegiem czasu wielka mnogość zagadnień dotyczących rzeczywistości, w różnych jej odmianach, przestała mieć charakter filozoficzny, stając się domeną tzw. nauk szczegółowych. W mniejszym stopniu dotyczy to poznania, chociaż i tu pewne zagadnienia zostały przekazane psychologii, logice matematycznej, a obecnie nowej dyscyplinie zwanej kognitywistyką (cognitive science). Jedynie wartościowanie pozostało w całości w zasięgu filozofii i — zdaniem niektórych — właśnie związek z wartościowaniem świadczy o filozoficznym charakterze zagadnienia.

Zróżnicowaniu przedmiotowemu filozofii odpowiada różnorodność podejmowanych przez filozofię zagadnień. Tę ostatnią potęguje fakt, iż filozofowie często kwestionują ważność względnie sensowność pewnych zagadnień filozoficznych, a nawet całej tradycyjnej problematyki filozoficznej, proponując w jej miejsce nową. Takie praktyki filozofów dowcipnie scharakteryzował pewien filozof współczesny pisząc: „Kleryk, który traci wiarę, rezygnuje z powołania i zrzuca sukienkę. Filozof, który traci wiarę [w filozofię — A. N.], — podaje nową definicję filozofii”"4.

Wspomnieć tu trzeba również o wielkiej różnorodności stylów filozofowania przejawiającej się w sposobie wypowiedzi. Nieuprzedzony czytelnik, który na podstawie

\footnotetext{
${ }^{4}$ E. Ge 11 n e r, Słowa i rzeczy, Książka i Wiedza, Warszawa 1984, s. 401.
} 
informacji katalogowej sięgnie po książkę zakwalifikowaną do działu „Filozofia”, może uzyskać radykalnie różne przeświadczenia o tym, czym jest filozofia, w zależności od tego, czy będzie to dzieło posługujące się językiem i symboliką algebry abstrakcyjnej (są również takie!), czy też dzieło przemawiające językiem hermetycznej poezji intelektualnej, często niezrozumiałym dla większości filozofów o innych upodobaniach (a niewykluczone, że również dla samego autora).

Czym wytłumaczyć przedstawiony powyżej stan rzeczy? Otóż filozofia jest — jak już wspomnieliśmy — dyscyplina akademicką od wieków wykładaną i uprawianą na uniwersytetach. Jako dyscyplina akademicka jest filozofia zarazem pewną profesją. W rezultacie każde dzieło, które przynajmniej pewna grupa profesjonalnych i cieszących się odpowiednim autorytetem filozofów uzna za filozoficzne, zostaje wraz z podjętą w nim problematyką zaliczone do filozofii. Zgodnie z tym, co zauważyliśmy już wcześniej, dzieło filozoficzne nie musi być kontynuacją pewnej tradycji filozoficznej; świadectwem jego filozoficzności może być również to, że tradycję tę kwestionuje. Zatem nic dziwnego, że granice filozofii są kręte i ruchome.

Prawie wszystko, co powiedziano powyżej o filozofii w ogólności, stosuje się również — w odpowiedniej proporcji — do będącej jej fragmentem filozofii nauki. Rację jej istnienia stanowi fakt, iż szereg pytań dotyczących nauki ma rzeczywiście charakter filozoficzny. Samo pytanie „Czym jest nauka?” jest zagadnieniem filozoficznym z dwóch powodów. Po pierwsze dlatego, że uprawianie nauki jest poznawaniem jakiejś rzeczywistości (niektórzy filozofowie współcześni wprawdzie temu przeczą, co wszakże - w świetle wcześniejszych spostrzeżeń — nie pozbawia zagadnienia charakteru filozoficznego); po drugie, ponieważ każda odpowiedź na pytanie, czym jest nauka, wiąże się z ustaleniem granic nauki. Trzeba bowiem podjąć decyzję, które to dyscypliny, a także poszczególne twierdzenia, zagadnienia i hipotezy pretendujące do miana naukowych uznamy za rzeczywiście naukowe, a to wiąże się z ich wartościowaniem, które — jak już zauważyliśmy — jest domeną filozofii.

Odpowiedzi na pytanie, czym jest nauka, a także na szereg bardziej szczegółowych pytań dotyczących nauki, należy zatem szukać w filozofii. Wzrastające zainteresowanie nauką, związane z coraz większym jej wpływem na losy jednostek i społeczeństw, sprawiło, że na przestrzeni ostatnich kilkudziesięciu lat wzrosło również zainteresowanie filozofią nauki.

Filozofia nauki, podobnie jak cała filozofia, ma charakter niejednorodny. Znaczna część (ale nie całość) jej problematyki osadzona jest w wiekowej tradycji filozoficznej sięgającej Platona i Arystotelesa ${ }^{5}$ i stanowi jej mniej lub bardziej wierną kontynuację. Stąd zapleczem filozofii nauki — w sensie rezerwuaru pojęć i zagadnień — są tradycyjne działy filozofii, takie jak epistemologia (teoria poznania) $\mathrm{i}$ - w mniejszym stopniu

\footnotetext{
5 Jego Analityki mogą uchodzić za pierwszy traktat z dziedziny filozofii nauki. Traktat ten wpłynął w istotny sposób na ukonstytuowanie się wzorca nauki jako systemu aksjomatyczno-dedukcyjnego. Wzorzec ten, zastosowany po raz pierwszy w praktyce przez Euklidesa w jego Elementach, w czasach nowożytnych traktowany był często jako obowiązujący w odniesieniu do wszystkich nauk.
} 
— ontologia (traktująca o najogólniejszych podziałach i właściwościach wszystkiego, co istnieje). Obok scharakteryzowanego powyżej nurtu nawiązującego do tradycji filozoficznej istnieje również drugi nurt, który się wspomnianej tradycji przeciwstawia. Jeśli obu tym nurtom przyznaje się prawo obywatelstwa w filozofii nauki, to dzieje się tak z dwóch powodów. Po pierwsze dlatego, że stawiają sobie one ten sam cel: wyjaśnienie (względnie dostarczenie rozumienia) tego zjawiska kulturowego, jakim jest nauka; po drugie, owe dwa nurty oddziałują na siebie w toku toczonych polemik, co wpływa na modyfikację zajmowanych wcześniej stanowisk i przyczynia się do ich doskonalenia.

Wewnętrzne zróżnicowanie filozofii nauki znajduje również wyraz w różnorodnych stylach jej uprawiania. Są filozofowie, którzy uprawiają filozofię nauki pod hasłem metodologii nauk. Oznacza to zazwyczaj, że w polu ich zainteresowań na pierwszym planie znajdują się poszczególne czynności i procedury składające się na badania naukowe, takie jak kształtowanie pojęć, formułowanie zagadnień, stawianie hipotez, tworzenie teorii itp. Inni z kolei filozofowie preferują takie problemy z zakresu filozofii nauki, które dają się ująć za pomocą aparatury formalnej zaczerpniętej z logiki i matematyki; dociekania swoje przedstawiają wówczas jako metodologię formalnq lub logicznq teorię nauki. Należy w tym miejscu zauważyć, że logika współczesna w istotny sposób przyczyniła się do powstania filozofii nauki i wywarła na niej swoje piętno, co później spotkało się z krytyką filozofów utrzymujących, że obraz nauki ukształtowany przy pomocy logiki jest zdeformowany, a w najlepszym wypadku jednostronny. Filozofów tych bardziej niż gotowe teorie i inne rezultaty dociekań naukowych interesuje proces kształtowania się wiedzy naukowej, a ponieważ nauka jest dziełem ludzi tworzących pewne wspólnoty, próbują rozwój nauki wyjaśniać czynnikami socjologicznymi i psychologicznymi ${ }^{6}$. Problem, jakie to okoliczności i motywy skłaniają uczonych do odrzucania pewnych teorii i zastąpienia ich nowymi jest jednym z najczęściej dyskutowanych zagadnień współczesnej filozofii nauki.

Przedmiotem dociekań filozoficznych pod hasłem „filozofia nauki” są z reguły nauki przyrodnicze, takie jak fizyka, chemia, biologia. Filozoficzna refleksja nad matematyką stanowi dziedzinę wyodrębnioną jako filozofia matematyki. Punktem styczności między filozofią nauk przyrodniczych a filozofią matematyki jest problematyka zastosowań matematyki.

Ponieważ nauka, podobnie jak sztuka i religia, jest zjawiskiem kulturowym, filozofia nauki, niezależnie od stosowanych narzędzi i metod, należy do nauk o kulturze, jak niekiedy charakteryzuje się nauki humanistyczne. Podobnie jak w innych naukach humanistycznych, w filozofii nauki istnieją szkoły różniące się pod względem akceptowanych podstawowych założeń i stylu filozofowania. Szkoły takie, zazwyczaj związane z określonymi ośrodkami akademickimi, kultywują lokalną tradycję. Jednakże istnieją również

\footnotetext{
${ }^{6}$ Przykładem takiego podejścia jest książka T. S. Kuhna, wymieniona w następnym przypisie.
} 
szkoły o zasięgu ponadnarodowym. Często powstanie nowej szkoły filozoficznej wiąże się z publikacją określonego dzieła, które inicjuje nową problematykę podejmowaną następnie przez innych. Przykładami takich dzieł są książki Karla Poppera, Thomasa Kuhna, Josepha Sneeda i Imre Lakatosa ${ }^{7}$. Również Kazimierz Ajdukiewicz, jeden z najwybitniejszych współczesnych filozofów polskich, sformułował oryginalny projekt filozofii nauki, który upowszechniał pod nazwą metodologii rozumiejącej lub logiki pragmatycznej ${ }^{8}$.

7 Mam tu na myśli dzieła: K. Po p pe r, Logik der Forschung (1935), przekład polski: Logika odkrycia naukowego, PWN, Warszawa 1977; T. S. K u h n, The Structure of Scientific Revolution, (1962), przekład polski: Struktura rewolucji naukowych, PWN, Warszawa 1968; nowy przekład: ALETHEIA, Warszawa 2001; J. D. S n e e d, The logical Structure of Mathematical Physics, D. Reidel, Dordrecht 1971; I. L a k a t o s, Falsification and the methodology of scientific research programmes, (1970), polski przekład w: I. L a k a t o s, Pisma z filozofii nauk empirycznych, PWN, Warszawa 1995.

${ }^{8}$ Różne sformułowania tego programu zawarte są w: K. A j d u k i e w i c z, Język i poznanie, PWN, Warszawa, t. I (1960), t. II (1965) oraz w tegoż autora: Logika pragmatyczna, PWN, Warszawa 1975. 


\section{Wykład drugi}

\section{JAK PODZIELIĆ NAUKĘ?}

Ponieważ wielu ludzi sądzi, że wiedza naukowa i metody jej uzyskiwania są lepsze od innych ${ }^{1}$, terminy nauka, naukowy są terminami wartościującymi dodatnio, natomiast określenie nienaukowy ma wymowę pejoratywną. Skutkiem tego jest tendencja do poszerzania zakresu terminu nauka, między innymi przez mnożenie dyscyplin naukowych ${ }^{2}$. Problem granic nauki i kryteriów naukowości jest jednym z poważniejszych zagadnień podejmowanych przez filozofię nauki. Tutaj posłużymy się instytucjonalnym kryterium naukowości, według którego nauką jest wszystko, co jest przedmiotem nauczania w szkołach wyższych i zarazem dziedziną, którą w tychże szkołach i innych instytucjach usiłuje się wzbogacać. W myśl takiego kryterium, w gronie dyscyplin naukowych znajdą się takie niekwestionowane dyscypliny jak matematyka, fizyka, biologia, geologia, historia, literaturoznawstwo, obok takich, których naukowość bywa kwestionowana, jak filozofia i teologia, jak również nowinki w rodzaju irenologii i gender studies ${ }^{3}$. Jest oczywiste, że nawet jeśli ograniczymy się do nauk legitymujących się długą tradycją, to niewiele da się o nich powiedzieć, jeśli miałoby to być trafne w odniesieniu do wszystkich tych nauk. Ten oraz inne względy wskazują na potrzebę klasyfikacji względnie typologii nauk ${ }^{4}$.

Historycznie pierwsza klasyfikacja nauk pochodzi od Arystotelesa. Podzielił on nauki na teoretyczne, praktyczne i wytwórcze. Wśród teoretycznych wyróżnił filozofię pierwsza (nazwaną później metafizyka), matematykę i fizykę. Jako zasadę zróżnicowania wskazał tu ogólność twierdzeń. Filozofia pierwsza jest nauką o „bycie jako takim”, a zatem

\footnotetext{
${ }^{1}$ Pogląd ten, zwłaszcza w wersji, iż tylko wiedza naukowa przedstawia jakąś wartość i zasługuje na zaufanie, nosi nazwę scjentyzmu. Słowo scjentyzm ma jednakże również drugie znaczenie, przy którym oznacza pewną ideologię, według której nauka może odpowiedzieć na wszystkie pytania istotne dla człowieka i rozwiązać wszystkie problemy dręczące ludzkość.

${ }^{2}$ Mnożenie dyscyplin naukowych nie zawsze jest zjawiskiem nagannym, zwłaszcza gdy tworzy się nowe dyscypliny na pograniczu dyscyplin już istniejących i cieszących zasłużonym uznaniem.

3 Ta pierwsza jest nauką o pokoju, druga — o doniosłych skutkach zróżnicowania ludzkości na płeć żeńską i męską.

4 Odróżniamy tu klasyfikację od typologii, ponieważ klasyfikacja (inaczej: podział logiczny) musi być rozłączna i wyczerpująca; typologia tego drugiego warunku spełniać nie musi i na ogół nie spełnia, wskazując jedynie istotne — z pewnego punktu widzenia — „typy” przedmiotów.
} 
o wszystkim, co istnieje, wraz z niematerialną ,pierwszą przyczyną" wszystkich pozostałych rzeczy utożsamianą z Bogiem (stąd filozofię pierwszą Arystoteles nazywa niekiedy teologia). Matematyka traktuje o liczbach i formach geometrycznych przedmiotów materialnych, ale traktowanych w oderwaniu od nich. $\mathrm{O}$ tych samych przedmiotach traktuje fizyka, uwzględniając dodatkowo ich zdolność do ruchu. Jak widać, dzieląc nauki teoretyczne, Arystoteles stosuje kryterium przedmiotowe, czyli ma na względzie to, o czym te nauki mówią, natomiast nie dostrzega różnic metodologicznych między nimi. Nauki teoretyczne tworzą - jego zdaniem — hierarchiczną całość opartą na aksjomatach, których ogólność maleje w kierunku od filozofii pierwszej do fizyki. Nauki praktyczne to — według Arystotelesa — etyka, polityka, ekonomika i medycyna; ich przedmiotem jest działanie zmierzające do przekształcenia tego, „,co może być inne niż jest”. Z kolei nauki wytwórcze traktują o sposobach wytwarzania przedmiotów ,zewnętrznych w stosunku do wytwarzającego".

Po Arystotelesie wielu innych myślicieli podejmowało zadanie klasyfikacji nauk. Na uniwersytetach średniowiecznych obowiązywał hierarchiczny układ „Siedmiu umiejętności wyzwolonych" (septem artes liberales), na który składało się trivium: gramatyka, retoryka i dialektyka (czyli logika) oraz quadrivium: arytmetyka, geometria, astronomia i muzyka (!). Nad nimi wznosiły się ,trzy filozofie”: fizyka, metafizyka i teologia. Z epoki nowożytnej pochodzą klasyfikacje Francisa Bacona (1561-1626), oraz autorów Wielkiej encyklopedii francuskiej (1751) — d'Alemberta i Diderota. W czasach nam bliższych godne uwagi klasyfikacje nauk stworzyli: filozof Auguste Comte (1798-1857), fizyk André Marie Ampère (1775-1836) i psycholog Wilhelm Wundt (1832-1920). W klasyfikacji pochodzącej od tego ostatniego pojawia się jeszcze dziś często stosowany najogólniejszy podział nauk na filozofię i nauki szczegółowe ${ }^{5}$, podział nauk szczegółowych na formalne (do których zalicza się matematykę) i realne, a tych z kolei na przyrodnicze i humanistyczne.

Klasyfikacje i typologie nauk przyjmują różną postać, w zależności od celów, którym mają służyć. Często są to cele praktyczne związane z administrowaniem nauką, a wówczas istotną rolę odgrywają więzi kooperacyjne między dyscyplinami naukowymi. $\mathrm{Na}$ tej zasadzie wyróżnia się — na przykład — nauki ścisłe, zaliczając do nich matematykę wraz z fizyką i chemią, chociaż między matematyką (zwłaszcza tzw. matematyką czystą) a fizyką i chemią zachodzą bardzo istotne różnice. Bardzo szczegółowe i „piętrowe” klasyfikacje nauk mają na ogół charakter „,biblioteczny”, czyli służą po prostu do klasyfikacji publikacji, a ich zadaniem jest ułatwianie wyszukiwania prac na ściśle określony temat.

W powszechnym odczuciu, za najbardziej podstawowy uchodzi podział nauk na matematyczno-przyrodnicze i humanistyczne. W podziale tym, łącząc matematykę z naukami

\footnotetext{
5 Podział ten nawiązuje do pozytywistycznej koncepcji filozofii (sformułowanej przez Auguste’a Comte’a) jako uogólnienia nauk szczegółowych, zwanych również ,pozytywnymi”. Chociaż wiele pojęć filozoficznych (zwłaszcza należących do ontologii) wyróżnia się nadzwyczajną ogólnością, ta pozytywistyczna wizja filozofii nie odpowiada stanowi faktycznemu, lecz jest pewnym programem uprawiania filozofii.
} 
przyrodniczymi, przypisuje się jej rolę narzędzia w większym lub mniejszym stopniu wykorzystywanego w pozostałych. Jednak nauki humanistyczne postrzegane są jako coś radykalnie różnego od nauk matematyczno-przyrodniczych, niezależnie od tego, iż współcześnie w pewnych naukach humanistycznych korzysta się z usług matematyki nawet w większym stopniu, niż w niektórych naukach przyrodniczych. Świadectwem przeświadczenia o istotnej różnicy między naukami matematyczno-przyrodniczymi a humanistycznymi może być fakt, iż w języku angielskim nie ma określenia obejmującego oba wspomniane typy nauk, a słowo science, które my zwyczajowo przekładamy na „,nauka”, odnosi się tylko do tych pierwszych (nauki humanistyczne noszą nazwę humanities).

Przekonanie o przepaści dzielącej omawiane tu typy nauk nie jest powszechne. Sporą liczbę zwolenników ma pogląd, iż nauki humanistyczne należy uprawiać metodami nauk przyrodniczych, z czego wynika, że podkreślane przez innych różnice między nimi można sprowadzić do różnic w przedmiocie, a tym samym mogą one okazać się nie większe, niż między dwiema naukami przyrodniczymi. Poglądowi temu, zwanemu naturalizmem, towarzyszy na ogół przeświadczenie o „zapóźnieniu” nauk humanistycznych i hasło ich „unaukowienia”.

Tendencje do zacierania granicy między naukami przyrodniczymi a humanistycznymi nie są w stanie przysłonić różnic, które tu faktycznie zachodzą, stąd wielu filozofów próbowało wyjaśnić, na czym polega specyfika nauk humanistycznych. Charakteryzowanie ich — zgodnie z etymologią przymiotnika humanistyczny — jako „nauk o człowieku” jest oczywiście niewystarczające, ponieważ człowiek jest częścią przyrody, a antropologia, będąca niewątpliwie nauką o człowieku, jest częścią biologii. W tradycji filozofii niemieckiej leży określanie nauk humanistycznych mianem Geistenswissenschaften (nauki o duchu) bądź Kulturwissenschaften (nauki o kulturze). Pierwsze z tych określeń odwołuje się do kontrowersyjnego założenia o istnieniu obiektywnego i ponadindywidualnego ducha, który przejawia się w dziejach ludzkości; drugie — zakłada jako jasne i oczywiste przeciwstawienie kultury naturze. Wydaje się, że najprostszą i w miarę adekwatną charakterystyką nauk humanistycznych jest stwierdzenie, iż są to nauki o świadomych $i$ celowych zachowaniach ludzi $i$ wytworach (lub innych skutkach) takich zachowań. Oczywiście, gdy mowa tu o wytworach, należy mieć na względzie nie tylko wytwory materialne, lecz również takie jak: teorie naukowe, doktryny polityczne, normy prawne, wierzenia religijne itp. Przytoczona tu charakterystyka nauk humanistycznych jest charakterystyką przedmiotowa, która jednakże pociąga za sobą pewne dystynkcje metodologiczne, ponieważ jest rzeczą wątpliwą, czy wspomniane tu niematerialne wytwory ${ }^{6}$ ludzkości można badać metodami nauk przyrodniczych.

Jakie podziały nauk są szczególnie istotne z punktu widzenia filozofii? Oczywiście takie, gdzie zasadą podziału są względy teoretyczne ważne z punktu widzenia pewnej pro-

\footnotetext{
${ }^{6}$ Określenie „wytwory niematerialne” bywa rozumiane jako wytwory „ducha obiektywnego”, który działa za pośrednictwem ludzi, bądź po prostu jako wytwory człowieka będące przedmiotami abstrakcyjnymi, przeciwstawianymi tu przedmiotom materialnym konkretnym.
} 
blematyki filozoficznej. Niewątpliwie najdłuższą tradycję ma podział nauk na aprioryczne i aposterioryczne. Jest to podział związany z podstawowym zagadnieniem epistemologicznym dotyczącym źródeł i podstaw ludzkiej wiedzy. Wiedza aprioryczna to wiedza uzyskana niezależnie od doświadczenia zmysłowego, a jeśli nawet doświadczenie takie jest tu niezbędne, to nie ono sprawia, że wiedza taka zasługuje na zaufanie. Wiedzę aprioryczną charakteryzowano w przeszłości bądź jako wrodzonq, bądź jako uzyskaną na drodze rozumowania, niezawodnej intuicji, bądź wreszcie jako produkt konwencji ustalających znaczenie wyrażeń. Wiedza aprioryczna (w przeciwieństwie do aposteriorycznej, czyli opartej na doświadczeniu) uchodziła zawsze za pewną i niepodważalną, a taki charakter przypisywano niemal powszechnie matematyce oraz pewnym zasadom logicznym, jak zasada niesprzeczności, zasada wyłączonego środka i zasada tożsamości (zwłaszcza w interpretacji przedmiotowej, czyli ontologicznej). Immanuel Kant (1724-1804), który miał własny, oryginalny pogląd na podstawy wiedzy apriorycznej, zaliczał do niej również „matematyczne przyrodoznawstwo", mając na myśli fizykę Newtona.

Innym tradycyjnym podziałem nauk jest ich podział na dedukcyjne i indukcyjne. Ponieważ dedukcja i indukcja są rodzajami rozumowań uzasadniających, podział ten należałoby rozumieć następująco: nauki dedukcyjne to takie, w których spośród rozumowań uzasadniających dozwolona jest wyłącznie dedukcja, natomiast indukcyjne to takie, w których dopuszczalne są również inne sposoby rozumowań, na przykład indukcja ${ }^{7}$.Przy takiej interpretacji za nauki dedukcyjne mogłyby uchodzić matematyka i logika formalna, zaś za indukcyjne - wszystkie pozostałe. Pospolita jest jednakże nieco inna interpretacja omawianego podziału, w myśl której nauki dedukcyjne to nauki, w których teorie mają postać systemu aksjomatycznego, którego aksjomaty są niepodważalne, zaś wszystkie pozostałe twierdzenia, uzyskiwane z aksjomatów drogą dedukcji, czerpią uzasadnienie z aksjomatów i — wobec niezawodności dedukcji — są również niepodważalne. Taka interpretacja pojęcia nauki dedukcyjnej sugeruje, że nauki dedukcyjne pokrywają się z naukami apriorycznymi, zaś indukcyjne, jako pozostałe - z aposteriorycznymi.

Koncepcja systemu aksjomatycznego jako systemu wiedzy pewnej nawiązuje do Arystotelesowskiego ideału „wiedzy demonstratywnej”, , który jeszcze w XVII wieku traktowano jako obowiązujący w odniesieniu do całej nauki. Wzorcem, który usiłowano naśladować, był system geometrii zawarty w Elementach Euklidesa. Jednakże już w XVII wieku pojawia się nowe podejście do systemów aksjomatycznych, które mają przedstawiać wiedzę o przyrodzie. Zwycięża świadomość, że jest to wiedza oparta na doświadczeniu. Stąd Newton swoje badania nazywa „filozofią eksperymentalną”, a o ,pierwszych zasadach” swojego systemu mechaniki, które nazywa „aksjomatami, czyli prawami ruchu” (axiomata sive leges motu) powie, że ,zasady te są wyprowadzone

\footnotetext{
7 Termin indukcja bywa różnie rozumiany, zawsze jednak oznacza rozumowanie zawodne, czyli takie, które od przesłanek prawdziwych prowadzi niekiedy do wniosku fałszywego. Uwaga ta nie dotyczy tzw. indukcji matematycznej, która jest wnioskowaniem dedukcyjnym opartym na twierdzeniu matematycznym zwanym zasada indukcji jako przesłance.

${ }^{8} \mathrm{Tj}$. takiej, gdzie wszystko jest dowiedzione na podstawie intuicyjnie oczywistych ,pierwszych zasad”.
} 
ze zjawisk i uogólnione za pomocą indukcji" ${ }^{9}$. Ów nowy pogląd na naturę systemu aksjomatycznego i sposób uzasadniania jego aksjomatów znacznie lepiej scharakteryzował współczesny Newtonowi Ch. Huygens w przedmowie do Traité de la lumiere (1690):

Można obecnie znaleźć rodzaj dowodu, który nie daje tak wielkiej pewności jak dowód geometryczny i w istocie jest bardzo odmienny od dowodu używanego przez geometrów, ponieważ ci ostatni udowadniają swoje twierdzenia za pomocą pewnych i niewzruszonych zasad, podczas gdy tutaj zasady są sprawdzane przez ich konsekwencje. Natura przedmiotu nie pozwala na inne jego traktowanie. Niemniej jednak można osiągnąć w ten sposób pewien stopień prawdopodobieństwa, który często nie wiele mniej znaczy od zupełnej pewności. Zdarza się to, gdy konsekwencje przyjętych przez nas zasad doskonale zgadzają się z obserwowanymi zjawiskami, a zwłaszcza gdy takie wypadki potwierdzenia są liczne, przede wszystkim zaś, kiedy możemy sobie wyobrazić i przewidzieć nowe zjawiska, wynikające z przyjętych przez nas hipotez, a następnie stwierdzić, że nasze oczekiwania spełniły się ${ }^{10}$.

Z chwilą, gdy powszechnie uprzytomniono sobie, że aksjomaty systemu mogą mieć charakter założeń hipotetycznych, których nie tyle uzasadnieniem, co potwierdzeniem mogą być ich, niekiedy odległe, konsekwencje, fakt, iż pewna dziedzina wiedzy jest (lub może być) ujęta w system aksjomatyczny, stracił przypisywane mu wcześniej znaczenie. Podział nauk na dedukcyjne i indukcyjne został uzależniony od zasobu tolerowanych w danej dziedzinie rodzajów rozumowań i wyznaczał granicę między matematyką i logiką a resztą dyscyplin naukowych, nie przesądzając o innych ich cechach swoistych.

Wprowadzony przez Wundta podział nauk (z wyłączeniem filozofii) na formalne i realne został uznany za fundamentalny przez Rudolfa Carnapa (1891-1970), autora, który w istotny sposób przyczynił się do powstania nowoczesnej filozofii nauki korzystającej z narzędzi logiki. Zasady tego podziału nie są jasne i mogą być różnie interpretowane, lecz niezależnie od ich interpretacji, okazuje się, że naukami formalnymi mają być logika formalna i „,czysta” matematyka ${ }^{11}$.

Omówione powyżej trzy dwudzielne klasyfikacje nauk wiążą się z pewnymi zagadnieniami filozoficznymi i ich poprawność uzależniona jest od sposobu rozwiązywania tych zagadnień. Na przykład, w myśl stanowiska skrajnego empiryzmu ${ }^{12}$, wiedza aprioryczna w ogóle nie istnieje, a tym samym dzielenie nauk na aprioryczne i aposterioryczne jest bezzasadne. Rzecz charakterystyczna, że wszystkie wspomniane tu podziały, niezależnie od stosowanych kryteriów, oddzielają matematykę i logikę od pozostałych nauk. Ma to niewątpliwie jakieś podstawy. W tej sytuacji nauki pozostałe

\footnotetext{
${ }^{9}$ W liście do R. Cotesa z 1712 r.

10 Przytaczam tu tak obszerny cytat (za A. C. Crombie, Nauka średniowieczna i początki nauki nowożytnej, t. II, Instytut Wydawniczy PAX, Warszawa 1960, s. 398), również dlatego, że jest to wypowiedź siedemnastowiecznego autora, której nie powstydziłby się niejeden filozof współczesny.

${ }^{11}$ Różne znaczenia przymiotnika formalny, również w zastosowaniu do dyscyplin naukowych staram się wyjaśnić w książce Gramatyka i prawda, Biblioteka Myśli Semiotycznej, Warszawa 1999, w rozdziale IV pt. Czy logika formalna jest formalna? Do kwestii tej powrócimy w wykładzie jedenastym traktującym o przedmiocie matematyki.

12 Reprezentowanego, między innymi, przez Johna Stuarta Milla (1806-1873), który również matematykę uważał za naukę empiryczną.
} 
wypadałoby podzielić po prostu na przyrodnicze i humanistyczne, lecz czy podział taki byłby użyteczny dla filozofii nauki?

Dzielenie nauk zawsze stwarza ryzyko, że pewne dyscypliny znajdą się poza klasyfikacją. Gdzie, na przykład, mamy umieścić teologię lub etykę normatywną, zakładając — jak chce wiele uprawiających je osób — że są to nauki. Ponadto, jak już zauważyliśmy, niewiele da się powiedzieć o wszystkich naukach łącznie. Zatem, czy nie lepiej wyróżnić kilka typów nauk, które mają wiele cech wspólnych, nie troszcząc się o to, czy wyczerpują one ogół nauk, a nawet czy owe typy są rozłączne? Wydaje się, że taka jest właśnie praktyka współczesnej filozofii nauki. Uogólnienia, które filozofia nauki proponuje, mają z reguły zasięg ograniczony i dotyczą tylko nauk pewnego określonego typu. Taki typ tworzą niewątpliwie nauki matematyczne, z którymi wiążą się swoiste problemy będące domena filozofii matematyki. Inny godny wyodrębnienia typ nauk tworzą nauki ścisłe, pod warunkiem, że z ich grona wyłączymy matematykę, która zwyczajowo bywa do nauk ścisłych zaliczana. Osobliwością tak rozumianych nauk ścisłych jest korzystanie w szerokim zakresie z pojęć i twierdzeń matematyki jako narzędzia, z czym wiąże się stosowanie pomiaru i konstruowanie tzw. modeli matematycznych badanych przedmiotów i zjawisk ${ }^{13}$. Dla tak scharakteryzowanych nauk ścisłych właściwe byłoby użyte przez Kanta określenie „matematyczne przyrodoznawstwo”, gdyby nie fakt, że charakterystykę tę spełniają również pewne dyscypliny zaliczane do nauk humanistycznych (względnie społecznych), jak ekonomia i demografia. Da się zauważyć, że większość dociekań, które w literaturze anglojęzycznej mieszczą się w zakresie philosophy of science, koncentruje się na naukach ścisłych. Osobną grupę nauk, z którymi wiążą się swoiste dla nich problemy, tworzą nauki, w których dominuje ewolucyjny punkt widzenia. Należą do niej przede wszystkim nauki biologiczne, ale — być może — nie tylko one. Również nauki humanistyczne nie tworzą grupy jednorodnej. Zapewne należałoby wśród nich wyodrębnić nauki, w których istotną rolę odgrywa wartościujący punkt widzenia, w odróżnieniu od takich, gdzie wartościowanie jest zjawiskiem marginalnym.

Spostrzeżenia powyższe prowadzą do wniosku, że nie jest możliwa jedna ogólna filozofia nauki, jeśli ma to być specjalność, która ma do powiedzenia coś istotnego.

\footnotetext{
13 Taką charakterystykę nauk ścisłych przyjąłem w książce Wprowadzenie do logiki nauk ścisłych, PWN, Warszawa 1990.
} 


\section{Wykład trzeci}

\section{CO ISTNIEJE?}

Filozofia nauki nawiązuje, w miarę potrzeby, do tradycyjnych działów filozofii. Z uwagi na to, że nie może pominąć kwestii przedmiotu poszczególnych dyscyplin naukowych, sięga do ontologii. Termin ontologia wywodzi się z greckiego słowa oznaczającego byt i pojawił się dopiero w XVII wieku, ale problemy zaliczane do ontologii należą do najstarszych problemów filozoficznych.

Zdaniem współczesnego filozofa amerykańskiego Willarda V. Quine'a (1908-2000) naczelny problem ontologii streszcza się w dwóch słowach: Co istnieje ${ }^{1}$ Na pytanie to tylko jeden filozof miał odwagę (a raczej czelność) odpowiedzieć: nic nie istnieje ${ }^{2}$; wszyscy pozostali zgadzali się, że coś istnieje, chociaż różnili się w kwestiach bardziej szczegółowych. Nie zawsze różnice zdań w kwestii istnienia przedmiotów pewnego rodzaju mają charakter kontrowersji ontologicznych. Dawne spory o to, czy istnieją kryształowe sfery podtrzymujące gwiazdy i planety, jak również współczesne spory o istnienie neutrin, kwarków i czarnych dziur, wprawdzie mają niekiedy wydźwięk światopoglądowy, ale nie są sporami ontologicznymi. Natomiast pewien aspekt ontologiczny ma spór między fizykami osiemnastowiecznymi o to, czy oprócz cząstek (molekuł) istnieją również pola sił (rozumiane jako obszar, w którym na cząstkę działa siła) lub o to, czy istnieją wyłącznie pola, gdyż rzekome cząstki są (jak utrzymywał Faraday) tylko „centrami sił". Rzecz w tym, że przedmioty wymienione tu wcześniej skłonni jesteśmy zaliczać do tej samej kategorii ontologicznej, natomiast cząstki i pola (jak je wówczas pojmowano) — do różnych kategorii ontologicznych. Co to są kategorie ontologiczne? Poprzestańmy na razie na wyjaśnieniu, że są to tak ogólne kategorie przedmiotów, że istotne różnice między przedmiotami należącymi do różnych kategorii nie dają się opisać w terminach poszczególnych nauk i dlatego właśnie są przedmiotem zainteresowań filozofii.

Wydaje się, że główna trudność związana z pytaniem „,co istnieje?” polega na tym, że oczekuje się odpowiedzi wyczerpującej, a zatem nie pomijającej niczego, co istnieje. Tymczasem trudno zaprzeczyć, że oprócz tego, co w pierwszej kolejności przychodzi nam na myśl, czyli tzw. konkretnych makroskopowych przedmiotów fizycznych (jak kamienie,

\footnotetext{
${ }^{1}$ W. V. O. Q u i n e, Z punktu widzenia logiki. Eseje logiczno-filozoficzne, PWN, Warszawa 1969, s. 9.

2 Jeden z sofistów współczesnych Sokratesowi imieniem Gorgiasz.
} 
drzewa, zwierzęta, domy, stoły itp.) istnieją również, na przykład: umysły i towarzyszące im wrażenia, wyobrażenia i myśli, liczby i operacje na nich, wielkości fizyczne, twierdzenia matematyczne, teorie fizyczne, utwory literackie i muzyczne itp. Istnieniu tego rodzaju przedmiotów (słowo przedmiot podobnie jak obiekt względnie byt rozumiemy tu jako obejmujące wszystko, co istnieje) trudno zaprzeczyć, nie popadając w sprzeczności. Zdania w rodzaju: Masa jest wielkościa fizycznq, ale wielkości fizyczne nie istnieja, Dwa jest liczba pierwsza, ale liczby nie istnieja, Myśl, że Księżyc jest krązkiem sera jest absurdalna, ale myśli nie istnieją są — w świetle logiki klasycznej — zdaniami wewnętrznie sprzecznymi. Mówiąc ogólnie: sprzecznością jest utrzymywać, że przedmioty pewnego rodzaju nie istnieją i jednocześnie przytaczać niewątpliwy przykład takiego przedmiotu.

Niektórzy filozofowie powzięli podejrzenie, że nasze przekonania o istnieniu tak wielkiej rozmaitości przedmiotów związane są z naszym nadmiernie urozmaiconym sposobem mówienia. Pozwala to przypuszczać, iż rezygnując z używania pewnych wyrażeń (zwłaszcza rzeczowników) i zwrotów, nie utracilibyśmy nic z zawartości informacyjnej naszych wypowiedzi. Natomiast rezygnując z pewnych form wypowiedzi (lub traktując je wyłącznie jako dogodne urozmaicenie stylistyczne), nie bylibyśmy już zobowiązani do uznawania istnienia pewnych obiektów, zwłaszcza budzących pewne zastrzeżenia ${ }^{3}$. Ideę tę można zilustrować następującym przykładem. Załóżmy, że mamy przed sobą pojedynczy egzemplarz róży. Możemy o niej powiedzieć: (1) Ta róża jest jaskrawoczerwona, (2) Jaskrawa czerwień jest własnościa tej róży, (3) Jaskrawość jest wtasnościa przystugująca czerwieni tej róży, (4) To, że ta róża jest czerwona, jest faktem. Jak łatwo zauważyć, wartość informacyjna tych zdań jest w pewnym sensie taka sama, natomiast: z (1) wynika jedynie, że istnieją róże, będące - z punktu widzenia ontologii zdroworozsądkowej — przedmiotami konkretnymi, czyli indywiduami, z (2) wynika natomiast, że istnieją również własności indywiduów (np. czerwień), zaś z (3) — że ponadto własności przystugujące własnościom indywiduów (np. jaskrawość będąca własnością czerwieni). Zdanie (4) postuluje istnienie faktów.

Określenia wyróżnione tu kursywą oznaczają kilka spośród wielu kategorii ontologicznych narzucanych nam przez nie poddany żadnym restrykcjom potoczny sposób mówienia. Zdań (2), (3) i (4) moglibyśmy oczywiście bez szkody przestać używać, jednak nie wynika stąd, że moglibyśmy bez uszczerbku dla zasobu wypowiadanych informacji zrezygnować ze wszystkich zdań implikujących istnienie własności bądź faktów.

Ontologia (rozumiana w tym miejscu nie jako dział filozofii, lecz jako system kategorii ontologicznych) związana z językiem naturalnym, którym posługują się w mniejszym lub większym stopniu również wszystkie dyscypliny naukowe, jest niesłychanie rozbudowana. Aby mówić o twierdzeniach matematycznych musimy zgodzić się na kategorię znaczeń

3 W szczególności Tadeusz Kotarbiński (1886-1981) zwrócił uwagę na zjawisko hipostazowania, czyli przekonania o istnieniu przedmiotów na tej podstawie, że w naszym języku występują odpowiednie nazwy, które do owych przedmiotów rzekomo się odnoszą. Kotarbiński głosił pogląd zwany reizmem, w myśl którego istnieją tylko konkretne przedmioty fizyczne. Ten skrajny pogląd trudno pogodzić z przekonaniem, że również teorie matematyczne mają swój przedmiot, a więc o czymś mówią. 
(sensów), ponieważ twierdzenie Pitagorasa nie jest zdaniem, lecz znaczeniem zdań wypowiadanych w różnych językach. Według pewnych filozofów i teoretyków literatury analiza utworów literackich wymaga wprowadzenia kategorii przedmiotów intencjonalnych. Przykładem przedmiotu intencjonalnego mógłby być Stanisław Wokulski, czyli człowiek odpowiadający dokładnie charakterystyce zawartej w Lalce Bolesława Prusa. Człowiek taki - jak wiadomo - nie istniał, czego pewni filozofowie nie chcą uznać, utrzymując, że wprawdzie nie istniał on jako przedmiot realny, natomiast istnieje jako przedmiot intencjonalny. Koncepcja przedmiotów intencjonalnych budzi szereg zastrzeżeń natury logicznej, a przede wszystkim prowadzi do powielenia wszelkich przedmiotów, o których mówimy, o ile przypisujemy im różne charakterystyki. Tak więc - w myśl tej koncepcji - oprócz historycznego (realnego) Napoleona istnieje tylu Napoleonów intencjonalnych, ile napisano o nim (a raczej o nich!) powieści i dzieł historycznych. Często dla podkreślenia różnicy między przedmiotami realnymi a intencjonalnymi mówi się o przysługujących im różnych sposobach istnienia: pierwsze istnieją realnie, drugie - tylko intencjonalnie. Również o przedmiotach konkretnych i przeciwstawianych im przedmiotach abstrakcyjnych (np. o liczbach) mówi się, że istnieją „,w innym sensie” lub „w inny sposób”. Zdaniem logików, a także znacznej części filozofów sens słowa „istnieje" oddaje tzw. kwantyfikator szczegółowy (inaczej: egzystencjalny) i nie ma powodu przypisywania mu różnych znaczeń. Różnica między cegłami a liczbami niewymiernymi nie polega na tym, że one istnieją inaczej, lecz na tym, iż są to zdecydowanie różne przedmioty. Można oczywiście utrzymywać, że liczby nie istnieją, ale trzeba wówczas znaleźć jakąś odpowiedź na pytanie, o czym mówią twierdzenia matematyczne, jeśli w ogóle o czymś mówią.

Główną wadą ontologii związanej z językiem naturalnym, gdzie poszczególne kategorie ontologiczne mają w znacznej części swoje słownikowe określenia (np. własność, relacja, stan rzeczy, zdarzenie, proces itp.) nie jest wielość tych kategorii, lecz raczej ich nieokreśloność, a nade wszystko niejasne między nimi powiązania. Ten stan ontologii, w dużym stopniu zdroworozsądkowej, wielu filozofów postrzegało jako niezadowalający, jednakże impuls do jego poprawy wyszedł od filozofujących matematyków i logików. Istotne znaczenie miało tu odkrycie, że pojęcie zbioru (mnogości) jest logicznie pierwotne względem pojęcia liczby i może posłużyć do wyjaśnienia, czym są liczby (naturalne, wymierne i niewymierne) oraz przyczynić się do sprecyzowania innych ważnych dla matematyki pojęć takich jak pojęcie funkcji, pojęcie pochodnej itp. Pojęcie zbioru (względnie klasy) jest niewątpliwie pojęciem ontologicznym, spokrewnionym znaczeniowo z takimi pojęciami używanymi tradycyjnie przez filozofów jak: gatunek, rodzaj, zakres pojęcia, a także własność. Znaczenie wspomnianego odkrycia wykraczało więc poza matematykę i przyczyniło się do tego, że po wielu perypetiach powstała pierwsza ontologia formalna, znana jako teoria typów. Idea naczelna tej teorii pochodzi od Bertranda Russella (1872-1970). Teoria, którą zaproponował, a następnie wspólnie z Alfredem N. Whiteheadem (1861-1947) rozwinął Russell, miała być systemem logiki rozumianej 
przedmiotowo tj. jako system najogólniejszych twierdzeń o rzeczywistości, a więc swego rodzaju ontologią. Paradoksalnie, Russell za wszelką cenę starał się wyeliminować z rozważań pojęcie klasy, co prowadziło do pewnych komplikacji. Podstawową ideę teorii typów, w wersji znanej jako prosta teoria typów, przedstawia się zatem zwykle w ujęciu pochodzącym od innych autorów.

Według prostej teorii typów rzeczywistość ma strukturę hierarchiczną i każdy przedmiot jest przedmiotem określonego typu i zarazem określonego rzędu, który informuje o jego pozycji w hierarchii. Podstawę hierarchii tworzą indywidua będące przedmiotami rzędu zerowego. Zbiory indywiduów i relacje między indywiduami (odpowiednio, dwuczłonowe, trójczłonowe i - ogólnie - $n$-członowe) tworzą typy rzędu pierwszego. Wszystkie przedmioty poza indywiduami, są zbiorami bądź relacjami, przy czym obowiązuje ogólna zasada, iż elementy dowolnego zbioru rzędu $n+1$ są przedmiotami rzędu $n$. Dopuszcza się istnienie relacji zachodzących między przedmiotami różnych typów, jednakże przedmioty będące członami relacji rzędu $n+1$ muszą być zawsze przedmiotami rzędu niższego, zaś przynajmniej jedna dziedzina relacji rzędu $n+1$ musi składać się z przedmiotów rzędu $n$. W niektórych wersjach prostej teorii typów wyróżnia się funkcje jako przedmioty innego typu niż relacje, przy czym na argumenty i wartości funkcji nakłada się analogiczne ograniczenia.

Wszystkie wspomniane tu ograniczenia okazały się niezbędne, aby zapobiec tzw. antynomiom teoriomnogościowym, takim jak antynomia zbiorów nie będących swoimi elementami i antynomia zbioru wszystkich zbiorów ${ }^{4}$.

Zgodnie z zamierzeniem Russella, teoria typów miała być podstawą całej matematyki, między innymi w tym sensie, iż każdy obiekt, którym zajmuje się matematyka miał być obiektem określonego typu. Aby zapewnić istnienie niezbędnych w matematyce zbiorów nieskończonych, Russell był zmuszony założyć, że istnieje nieskończenie wiele indywiduów, które — jego zdaniem — są konkretnymi obiektami fizycznymi. Wynikało stąd, że również na wyższych piętrach hierarchii jest miejsce dla (abstrakcyjnych, bo będących zbiorami lub relacjami) obiektów ze „świata realnego”. Teoria typów mogła zatem uchodzić za ontologię ogólną, pod warunkiem, że wszystko, co istnieje, daje się potraktować jako indywiduum, bądź zbiór, bądź relacja. Jak wiadomo, relacje (a także funkcje, będące odmianą relacji) można utożsamić z pewnego rodzaju zbiorami, mianowicie zbiorami uporządkowanych par, trójek itd. W ten sposób otwarła się perspektywa redukcji rozmaitych niejasnych kategorii ontologicznych do przedmiotów o precyzyjnie określonych własnościach formalnych i związkach wiążących je z przedmiotami innych kategorii. Dlatego właśnie możemy powiedzieć, że teoria typów była pierwszą próbą stworzenia ontologii formalnej.

\footnotetext{
4 Antynomią nazywa się rozumowanie, w którym na podstawie intuicyjnie oczywistych przesłanek dochodzi się do sprzecznych wniosków. W myśl pierwszej ze wspomnianych tu antymonii (zwanej antymonią Russella) zbiór wszystkich zbiorów nie będących własnymi elementami musiałby zarazem być i nie być swoim elementem. Założenia teorii typów wykluczają istnienie takiego zbioru, podobnie jak istnienie zbioru wszystkich zbiorów.
} 
Ze względu na swoją rolę względem matematyki, teoria typów uchodzi za pewną wersję teorii mnogości, czyli ogólnej teorii zbiorów. Jednakże właśnie w tej roli, tzn. jako podstawa matematyki, teoria typów, ze względu na pewne niewygody z nią związane, nie wytrzymała konkurencji z tzw. aksjomatyczna teoria mnogości stworzoną przez Ernesta Zermelo (1871-1953). Również z innych powodów teoria typów ma dziś jedynie wartość historyczną. Aktualność zachowała natomiast sama idea hierarchii typów w postaci względnej hierarchii typów, o której można mówić również na gruncie aksjomatycznej teorii mnogości.

Aksjomatyczna teoria mnogości nie wprowadza restrykcji pozwalających mówić wyłącznie o zbiorach określonego typu; przeciwnie, toleruje również tzw. zbiory mieszane, których elementy należą do różnych typów. Zermelo nie zakładał, że istnieje nieskończenie wiele indywiduów, chociaż dopuszczał w swojej teorii istnienie przedmiotów nie będących zbiorami (nazywał je ,praelementami”); istnienie zbiorów nieskończonych zapewniał sobie na innej drodze, która w teorii typów była niedostępna.

Współcześnie znanych jest co najmniej kilkanaście wersji aksjomatycznej teorii mnogości. Nasuwa się pytanie, czy któraś z nich może — podobnie jak teoria typów — pretendować do roli formalnej ontologii ogólnej. W pytaniu tym chodzi przede wszystkim o to, czy rzeczywiście wszystko, co istnieje jest indywiduum bądź zbiorem, którego formalne własności i związki z innymi zbiorami dają się opisać w teorii mnogości.

Skąd wszakże mamy wiedzieć, co naprawdę istnieje? Jednym z możliwych rozwiązań tego problemu - a lepszego zapewne nie znamy — jest przyjęcie za dobrą monetę tego, co mówią aktualne teorie naukowe. Chodzi tu oczywiście o teorie interpretowane realistycznie, $\mathrm{tj}$. jako zamierzony opis pewnej rzeczywistości, a nie instrumentalnie, $\mathrm{tj}$. jako dogodne narzędzie uzyskiwania trafnych przewidywań, odnoszących się do czegoś innego. W przypadku teorii interpretowanej realistycznie ma sens pytanie o jej zaangażowanie ontologiczne, czyli o to, jakie obiekty zobowiązani jesteśmy uznawać za istniejące, kiedy daną teorię uznajemy za prawdziwą. Zwrot „zaangażowanie ontologiczne teorii” pochodzi od wspomnianego na wstępie filozofa amerykańskiego W. V. Quine’a, który zaproponował również ścisłe kryterium owego zaangażowania. Kryterium to głosi: Każdy, kto daną teorię uważa za prawdziwą, musi uznać, że istnieją przedmioty należące do zakresu zmienności zmiennych, które w twierdzeniach tej teorii występują jako zmienne wiązane kwantyfikatorami. W sugestywnym ujęciu aforystycznym pochodzącym od samego Quine'a kryterium to brzmi: być znaczy być wartościa zmiennej zwiazanej. Jak łatwo zauważyć, kryterium to daje się bezpośrednio zastosować jedynie do teorii sformułowanych w języku rachunku logicznego operującego zmiennymi i wiążącymi je kwantyfikatorami. Język taki może korzystać z wielu rodzajów zmiennych reprezentujących różne rodzaje przedmiotów. Ogólnie przyjęte zasady interpretacji języków rachunków logicznych przewidują, że wartościami zmiennych mogą być wyłącznie indywidua bądź zbiory (zakładając, że relacje i funkcje też są zbiorami), zatem kryterium Quine'a jak gdyby przesądza problem wyboru ontologii adekwatnej względem nauki na 
rzecz ontologii teoriomnogościowej. Natomiast otwarte pozostaje pytanie, czy kryterium Quine'a można zastosować do teorii, które — jak to zwykle ma miejsce — sformułowane są w języku naturalnym, ewentualnie z udziałem symboliki różnej od logicznej. Odpowiedź brzmi: kryterium to daje się zastosować pod warunkiem, że potrafimy dokonać adekwatnej parafrazy teorii (tj. parafrazy nie zniekształcającej jej treści) na język odpowiedniego rachunku logicznego. Tu jednakże natykamy się na istotne trudności. Parafraza teorii na język rachunku logicznego oznacza jej formalizację ${ }^{5}$, co w przypadku zaawansowanych teorii matematycznych i fizycznych nie jest sprawą prostą. $Z$ drugiej strony, formalizacja teorii pozwala nie tylko określić jej zaangażowanie ontologiczne, lecz również badać inne jej własności za pomocą ścisłego aparatu pojęciowego wspó1czesnej logiki. Stąd w dociekaniach z dziedziny filozofii nauki, w których pragnie się zachować wysoki poziom ścisłości, rozprawia się o teoriach w taki sposób, jak gdyby były to teorie sformalizowane. Podejście to oznacza daleko idącą idealizację i chociaż metoda idealizacji jest szeroko w nauce stosowana (zwłaszcza w naukach ścisłych), to jednak — zdaniem pewnych filozofów — idealizacja posuwa się tu zbyt daleko. Opinia ta skłania bądź do rezygnacji z wszelkiej idealizacji i badania teorii naukowych w ich „postaci naturalnej”, bądź do stosowania innych sposobów formalizacji teorii. Z obu wspomnianymi tu tendencjami zetkniemy się w toku dalszych wykładów.

\footnotetext{
${ }^{5} \mathrm{O}$ formalizacji języków i teorii będzie mowa w wykładzie piątym i następnych.
} 


\section{Wykład czwarty}

\section{CZYM SĄ TEORIE NAUKOWE?}

Niezależnie od tego, czy mamy do czynienia z matematyką, fizyką, biologią, czy literaturoznawstwem, panuje niemal powszechna zgoda, że ostatecznym celem tych nauk jest dostarczenie teorii. Na ogół nie dotyczy to tzw. nauk stosowanych, których zadaniem jest opracowywanie technologii wytwarzania pewnych przedmiotów na podstawie teorii wypracowanych w innych naukach. Niekiedy słyszy się, że do stworzenia teorii nie dążą również tzw. nauki idiograficzne, które zadowalają się opisem zjawisk i — ewentualnie — ich wyjaśnianiem za pomocą teorii zaczerpniętych z innych dyscyplin naukowych, zwanych nomotetycznymi. Opinia ta wiąże się z tym, że od teorii oczekuje się ogólności, a niekiedy tzw. ścisłej ogólności, która nie przysługuje opisom zjawisk poszczególnych, nawet przedstawianych z sugestią, że można je uogólnić.

Wspomniana tu powszechna zgoda jest jednakże pozorna, a jej podstawą jest niefrasobliwe posługiwanie się słowem teoria na określenie tworów w istocie niezwykle zróżnicowanych. Nasuwa się zatem pytanie, czy produkty różnych dyscyplin naukowych określane wspólnym mianem teorii wiąże jakieś istotne podobieństwo. Aby zauważyć pewne istotne różnice, nie musimy porównywać teorii tak odległych od siebie (przedmiotowo i metodologicznie) jak teoria względności i teoria gatunków literackich; jak zobaczymy, również między teoriami matematycznymi a teoriami fizycznymi zachodzą poważne różnice.

Zgodnie z potocznym użyciem słowa teoria, każda teoria jest teorią czegoś, tzn. mówi o czymś, co składa się na przedmiot teorii. Przedmiot ten na ogół jest wskazywany przez nazwę danej teorii, taką jak: teoria grup, teoria grawitacji, kwantowa teoria pola, teoria ewolucji itp. Skłonni jesteśmy utrzymywać, że przedmiot teorii istnieje (w przeciwnym przypadku teoria mówiłaby o niczym) oraz, że twórcy teorii starają się, aby to, co teoria mówi o swoim przedmiocie, było prawda. Wynika stąd, że teoria powinna być zbiorem zdań oznajmujących wyposażonych $w$ określonq treść, ponieważ tylko takim zdaniom można przypisywać wartość logiczną prawdy bądź fałszu.

Wśród zdań składających się na teorie skłonni jesteśmy wyróżniać zdania w jakimś sensie bardziej podstawowe od innych. Zgodnie z wiekową (wywodzącą się od Arystotele- 
sa), ale ciągle żywą tradycją owe zdania podstawowe to aksjomaty teorii. Pogląd Arystotelesa, że owe aksjomaty to „,pierwsze zasady" stanowiące fundament teorii, podzielany jest współcześnie co najwyżej w odniesieniu do teorii matematycznych; w przypadku teorii z innych dziedzin aksjomaty uchodzą jedynie za środek ich kodyfikacji, tj. syntetycznego przedstawienia treści teorii za pomocą możliwie niewielu zdań.

Dla większości zagadnień podejmowanych w filozofii nauki pojęcie teorii jest pojęciem kluczowym w tym sensie, że rozwiązania tych zagadnień muszą pozostać mało konkretne i problematyczne, o ile pojęcie teorii nie zostanie odpowiednio sprecyzowane. Rozważmy zatem, czy przytoczona powyżej charakterystyka teorii odpowiada praktyce naukowej i towarzyszącym jej poglądom uczonych.

W przypadku teorii matematycznych - zwłaszcza w matematyce współczesnej — nie ulega wątpliwości, że jej twierdzenia są logicznie poprawnie zbudowanymi zdaniami oznajmującymi (a w każdym razie względnie łatwo dają się w takie zdania przekształcić). Natomiast w kwestii, czy twierdzeniom teorii matematycznych przypisuje się (w matematyce „czystej”, a nie w jej zastosowaniach) określoną treść, zdania matematyków są podzielone. Część z nich, hołdujących tzw. formalizmowi utrzymuje, że twierdzenia matematyczne pozbawione są określonej treści, a tym samym nie można mówić o ich prawdziwości (ani fałszywości). Nie można również utrzymywać, że istnieje coś takiego jak przedmiot teorii matematycznych. Zdaniem innych matematyków teorie matematyczne mają swój przedmiot, o którym można wypowiadać twierdzenia prawdziwe. Wspomniana tu różnica zdań ma oczywiście charakter filozoficzny i w zasadzie nie wpływa na sposób uprawiania matematyki.

Jaką postać mają teorie matematyczne? Jak wiadomo, matematyka, poczynając od Euklidesa, uchodziła za teren obowiązkowych zastosowań metody aksjomatyczno-dedukcyjnej i pod tym względem stanowiła wzór dla innych nauk. Geometria Euklidesa opierała się na ustalonej liście aksjomatów (co prawda — jak się później okazało — niekompletnej). W czasach nowożytnych pojawiło się wiele teorii matematycznych, lecz aksjomatów poszczególnych teorii matematycznych nikt już nie ustalał, zaś praktyka matematyczna pozwalała traktować jako aksjomat dowolne zdanie odznaczające się „oczywistością". Pierwsze dokładnie zaksjomatyzowane teorie matematyczne pochodzą dopiero z przełomu XIX i XX wieku. Są to: arytmetyka Peany, geometria Hilberta, teoria mnogości Zermeli. Współcześnie istnieje wielka mnogość teorii matematycznych, ale większość z nich nie ma własnych aksjomatów. Jak to pogodzić z poglądem, że metoda aksjomatyczno-dedukcyjna jest swoista dla matematyki? ${ }^{1}$ Rzecz w tym, że matematyka współczesna została zintegrowana na gruncie najogólniejszej teorii matematycznej, którą jest teoria mnogości, ta natomiast ma rzeczywiście postać teorii aksjomatycznej. Bogaty, czyli — jak to się mówi — „mocny dedukcyjnie” zestaw aksjomatów teorii mnogości

\footnotetext{
${ }^{1}$ Utrzymują tak, na przykład, autorzy hasła „Matematyka” w Wielkiej encyklopedii powszechnej PWN, S. Hartman i C. Ryll-Nardzewski, dodając, że „,stosowanie metody dedukcyjnej w dziedzinach nie dość abstrakcyjnych zawiodło — np. w Etyce Spinozy (XVII w.) lub we współczesnych próbach formalizacji niektórych działów fizyki teoretycznej”.
} 
okazał się wystarczającą podstawą całej matematyki, co pozwala mniej ogólne teorie matematyczne traktować jako wyspecjalizowane fragmenty teorii mnogości. Fragmenty te nie dają się ostro wyodrębnić $\mathrm{z}$ macierzystej teorii i w praktyce matematycznej nie ma takiej potrzeby, ponieważ poszczególne teorie często korzystają z pojęć i twierdzeń innych teorii. $\mathrm{W}$ rezultacie to, co się $\mathrm{w}$ matematyce nazywa teorią, na ogół nie jest ściśle określonym zbiorem zdań. Fakt ten można unaocznić na przykładzie teorii grup. Kluczowym pojęciem tej teorii jest pojęcie grupy, które można zdefiniować w języku teorii mnogości jak następuje:

Struktura algebraiczna $\mathrm{A}=\langle X, \otimes\rangle$ jest grupą wtedy i tylko wtedy, gdy dla dowolnych $x, y, z \in X$,

(1) $x \otimes(y \otimes z)=(x \otimes y) \otimes z$

(2) istnieje takie $a \in X$, że $x=y \otimes a$

(3) istnieje takie $a \in X$, że $x=a \otimes y$.

Warunki (1)-(3) nazywa się niekiedy aksjomatami teorii grup. W rzeczywistości nie są to aksjomaty w ścisłym tego słowa znaczeniu, ponieważ nie są one zdaniami, lecz tylko fragmentami zdania będącego definicją grupy. Twierdzeniami teorii grup nie są konsekwencje tych rzekomych ,aksjomatów”, lecz konsekwencje aksjomatów teorii mnogości wzbogaconych o przytoczoną definicję pojęcia grupy; oczywiście nie wszystkie takie konsekwencje, a tylko te, które „mówią coś istotnego” bądź o wszystkich grupach, bądź o poszczególnych rodzajach grup, bądź o pewnych konkretnych grupach. Powiedzenie „coś istotnego” znaczy tu „coś takiego, czego nie da się powiedzieć o innych strukturach algebraicznych". Wyjaśnienie to nie jest ścisłe, toteż zbiór możliwych twierdzeń teorii grup nie jest wyraźnie odgraniczony od pozostałych twierdzeń matematycznych. Jak widzimy, chociaż twierdzenia matematyczne wyróżniają się, na tle innych nauk, ścisłością sformułowań, to teorie matematyczne nie są ściśle określonymi zbiorami zdań.

Znacznie poważniejsze trudności napotkamy, gdy próbujemy ustalić, co określa się mianem teorii w fizyce. Jak wiadomo, w fizyce obficie korzysta się z formuł matematycznych, stąd często można spotkać się z opinią, że fizykę uprawia się w języku matematyki. Jeżeli matematyka ma swój własny przedmiot, to z pewnością nie pokrywa się on z przedmiotem fizyki, zatem jeśli fizykę uprawia się po prostu w języku matematyki, formuły matematyczne powinny znaczyć w fizyce co innego niż w matematyce. Czy istotnie tak jest?

Odwołajmy się do wyjaśnień znanego fizyka-teoretyka ${ }^{2}$. Utrzymuje on, że zadaniem fizyka jest konstruowanie matematycznych modeli zjawisk fizycznych. W tym celu ,...należy znaleźć prawo matematyczne, które będzie stanowiło podstawę matematycznego

${ }^{2}$ W. Ko p c z y ń s k i, A. Tr a u t m a n, Czasoprzestrzeń i grawitacja, PWN, Warszawa 1981. Książka ta przedstawia treść popularnych wykładów o teorii względności wygłoszonych przez Trautmana w ramach Wszechnicy PAN, opracowanych przez W. Kopczyńskiego. Stanowi ona jeden z nielicznych przykładów przedstawiania przez fizyka metodologicznych problemów fizyki. 
modelu danego zjawiska"3. W przypadku, gdy interesującym nas zjawiskiem jest ruch ciała w polu grawitacyjnym, tym ,prawem matematycznym” jest równanie różniczkowe $\ddot{\mathbf{r}}=\mathbf{g}$.

Jest to skrótowy zapis równania, którego postacią rozwiniętą jest:

$$
\ddot{\mathbf{r}}(t)=\mathbf{g}(t, \mathbf{r}(t))
$$

Zgodnie z konwencjami przyjętymi w matematyce, wszystkie występujące w tym równaniu symbole literowe są zmiennymi, przy czym:

(a) zmienna $t$ reprezentuje liczby z przedziału otwartego $T$ zawartego $\mathrm{w} \mathbb{R}$, gdzie $\mathbb{R}$ jest zbiorem liczb rzeczywistych;

(b) zmienna $\mathbf{r}$ reprezentuje funkcje odwzorowujące przedział $T \mathrm{w} \mathbb{R}^{3}$;

(c) zmienna $\mathrm{g}$ reprezentuje funkcje odwzorowujące iloczyn kartezjański $T \times \mathbb{R}^{3} \mathrm{w} \mathbb{R}^{3}$.

Symbol $\ddot{\mathbf{r}}$ oznacza tu drugą pochodną funkcji reprezentowanej przez $\mathbf{r}$, toteż aby formuła (1) miała sens, funkcja ta musi być podwójnie różniczkowalna.

Jest oczywiste, że równanie (1) zwane tu ,prawem matematycznym” jest — zgodnie z przypisaną mu powyżej interpretacją - formuła matematyczna, natomiast nie jest twierdzeniem matematycznym, ponieważ spełniają ją tylko niektóre funkcje reprezentowane przez zmienne $\mathbf{r}$ i g. Skoro, jak powiedziano, ,prawo matematyczne” ma stanowić ,,podstawę modelu matematycznego", nasuwa się pytanie, czym jest sam model. Tu autorzy cytowanej książki nie dają wyraźnej odpowiedzi. Pewne fragmenty sugerują, że ,,prawo matematyczne” i „model matematyczny” są tym samym, inne natomiast, że modelami matematycznymi poszczególnych ruchów ciał w polu grawitacyjnym są takie funkcje $\mathbf{r}$, które są rozwiązaniami równania (1) przy założeniu, że funkcje $\mathbf{r}$ oraz $\mathbf{g}$ spełniają pewne warunki dodatkowe. Ta druga interpretacja wydaje się bardziej naturalna, ponieważ zgodnie z potocznym znaczeniem słowa model, powinno zachodzić jakieś strukturalne podobieństwo między modelem a tym, czego on jest modelem, a wspomniane funkcje $\mathbf{r}$ rzeczywiście „odwzorowują” ruch, tj. zmiany położenia w czasie. Oczywiście nie powinniśmy z góry wykluczać innych interpretacji słowa model, być może mniej naturalnych, lecz za to bardziej użytecznych teoretycznie.

Poświęciliśmy tu sporo uwagi pojęciu modelu matematycznego, pozornie odbiegając od zagadnienia, czym są teorie w fizyce. Jeśli zadaniem fizyka jest budowanie modeli matematycznych, to wyłania się pytanie, jak te modele mają się do teorii fizycznych. Odpowiedź cytowanych wcześniej autorów jest mocno niejasna. Utrzymują oni, że kiedy prawo matematyczne „opisuje obszerną klasę zjawisk”, mamy do czynienia z teorią, a ponadto stwierdzają: „Rozgraniczenie między teorią a modelem nie jest zbyt ostre. Ogólnie mówiąc, modele stosują się do pojedynczych zjawisk lub do grup zjawisk podobnych, teorie zaś dostarczają zwykle modeli różnych zjawisk, nieraz pozornie dość

\footnotetext{
3 Tamże, s. 21-22.
} 
odległych" ". W powyższej charakterystyce teorii trudno dopatrzyć się konsekwencji. Prawdopodobnie utożsamia się tutaj model z ,prawem matematycznym”, tj. z pewnym równaniem. Równanie, które ma szeroki zakres zastosowań określa się mianem teorii, zaś równanie o mniejszym zakresie zastosowań - mianem modelu. Ponadto sugeruje się, że modele można w jakiś sposób „otrzymać” bądź „wyprowadzić” z odpowiednich teorii.

Utożsamianie teorii z pewnym równaniem lub układem równań (rzadziej nierówności) jest wśród fizyków dość powszechne i jest źródłem przekonania, że fizykę uprawia się w języku matematyki. Jednakże, jeśli równania takie coś opisują w ścisłym tego słowa znaczeniu, to są to pewne obiekty względnie struktury matematyczne, a nie zjawiska fizyczne. Te ostatnie mogą być przez nie opisywane jedynie w jakiś sposób pośredni. Ponadto równań tych nie można uważać za zdania (z domyślnymi kwantyfikatorami ogólnymi na początku), ponieważ przy takiej interpretacji byłyby zdaniami w oczywisty sposób fałszywymi. Można natomiast utrzymywać, że równania te wyznaczają lub definiują pewna klasę struktur matematycznych, analogicznych do tych, które rozważa się w ,czystej” matematyce (w rodzaju zdefiniowanej powyżej klasy grup). W omawianym przypadku byłaby to - nazwijmy ją tak — klasa matematycznych modeli ruchu punktu materialnego w polu grawitacyjnym (w skrócie: MRP), którą można zdefiniować następująco:

Trójka uporządkowana $\langle T, \mathbf{r}, \mathbf{g}\rangle$ jest MRP wtedy i tylko wtedy, gdy:

(1) $T$ jest otwartym przedziałem zbioru $\mathbb{R}$,

(2) $\mathbf{r}$ jest funkcją odwzorowującą $T w \mathbb{R}^{3}$ podwójnie różniczkowalną.

(3) g jest funkcją odwzorowującą $T \times \mathbb{R}^{3} \mathrm{w} \mathbb{R}^{3}$,

(4) dla dowolnych $t \in T, \ddot{\mathbf{r}}(t)=\mathbf{g}(t, \mathbf{r}(t))$.

Dysponując precyzyjnym pojęciem modelu matematycznego, nadal nie wiemy, jak mielibyśmy za pomocą takich modeli formułować twierdzenia o „,rzeczywistości fizycznej”, na którą składają się nie liczby i funkcje liczbowe, lecz wielkości fizyczne i zależności między nimi. Jeśli przy formułowaniu takich twierdzeń mamy czynić użytek z pojęcia modelu, to twierdzenia te powinny informować o tym, jak się mają modele do wspomnianej rzeczywistości. Mówiąc nieco dokładniej: powinny informować w jakich okolicznościach liczby uzyskane z pomiaru pewnych wielkości fizycznych spełniają zależności zachodzące w odpowiedniej strukturze matematycznej. Wyszczególnienie i ścisły opis wszystkich okoliczności, które grają tu rolę istotną, nastręcza poważne trudności, toteż w fizyce rzadko spotyka się sformułowania, które można traktować jako opis istniejącego stanu rzeczy „,bez niedomówień”. Jeśli ponadto uprzytomnimy sobie, że pomiar wielkości fizycznych obarczony jest z reguły pewną niedokładnością, a modele matematyczne są z góry traktowane jako przybliżone, to musimy przyznać, że trudności związane $\mathrm{z}$ formułowaniem twierdzeń i teorii (jeśli te ostatnie miałyby być zbiorami

\footnotetext{
4 Tamże, s. 22.
} 
twierdzeń) są istotnie olbrzymie. Stąd niektórzy filozofowie utrzymują, że wiedza fizyczna jest w dużym stopniu niewerbalizowalna (nie daje się wysłowić za pomocą zdań o określonej treści), lecz polega na praktycznej umiejętności trafnego dobierania modeli do rozwiązywania konkretnych zagadnień z zadowalającą dokładnością.

Powróćmy na koniec do postawionego wcześniej pytania: czy formuły matematyczne wykorzystywane w fizyce są tu interpretowane inaczej niż w matematyce? Pytanie to jest istotne, bo — być może — przy tej nowej, „fizycznej” interpretacji są one właśnie twierdzeniami fizyki? Pod wpływem szkolnej edukacji, która nie ominęła także dyplomowanych fizyków, skłonni jesteśmy na oba pytania odpowiadać twierdząco. W przypadku równania (1) skłonni jesteśmy mniemać, że występujące tu symbole literowe oznaczają wielkości fizyczne: $t$ - czas, $\mathbf{r}$ - położenie ciała względem ustalonego układu odniesienia, $\ddot{\mathbf{r}}$ - jego przyspieszenie, $\mathbf{g}$ - natężenie pola grawitacyjnego. Mając na względzie taką interpretację symboli, skłonni jesteśmy próbować oddać „fizyczny sens” równania (1) słowami:

(1') Przyspieszenie punktu materialnego $m \mathrm{w}$ momencie $t$ jest równe natężeniu pola grawitacyjnego $\mathrm{w}$ momencie $t \mathrm{w}$ tym punkcie $p$, w którym dany punkt materialny $m$ znajduje się w momencie $t$.

Mamy tu jednakże do czynienia z nieporozumieniem polegającym na tym, że w przedstawionej tu „fizycznej interpretacji” równania (1) jakoś automatycznie utożsamiamy wielkości fizyczne z ich liczbową reprezentacją, tymczasem wielkości fizyczne nie są liczbami, natomiast operacje matematyczne, o których tu mowa, wykonujemy na liczbach i funkcjach liczbowych. Kiedy fizycy mówią o „fizycznej interpretacji” lub „sensie fizycznym" równań, mają na myśli coś innego (i bardziej skomplikowanego) niż sens i zwykła (semantyczna) interpretacja wyrażeń. Sformułowanie (1') posiada zapewne jakieś walory dydaktyczne bądź heurystyczne, lecz jako twierdzenie obowiązujące ogólnie (tj. dla dowolnego $m, t$ i $p$ ) zawiera istotne braki: brak relatywizacji do układu odniesienia (wraz z zastrzeżeniem, że położenie mierzymy względem układu inercjalnego), a także założenia, iż na punkt materialny działa tylko siła grawitacyjna. Formułę (1') podobnie jak samo równanie (1), którego ma ona być interpretacją, trudno byłoby uznać za twierdzenie teorii, które wyraża dokładnie to, co fizycy pragną powiedzieć o fizycznej rzeczywistości. Do zagadnienia czym są teorie w fizyce powrócimy w jednym z następnych wykładów, po wyjaśnieniu, czym są wielkości i ich pomiar. 


\section{Wykład piąty}

\section{JEZYYKI I TEORIE SFORMALIZOWANE}

Najważniejszym i najbardziej wszechstronnym narzędziem porozumiewania się ludzi są naturalne języki etniczne. Pewne okoliczności geograficzno-historyczne sprawiające, że społeczności ludzkie żyją we względnej izolacji od innych, są przyczyną tego, że mówimy różnymi językami. Z kolei wielość języków etnicznych przyczyniła się do powstania językoznawstwa, w ramach którego, z biegiem czasu, znalazło się miejsce dla dociekań teoretycznych nad językiem jako takim. Języki etniczne są z natury językami mówionymi. Wynalazek pisma powiększył zasięg komunikacji językowej, umożliwiając — co prawda tylko jednostronną — komunikację między pokoleniami. Umożliwił on również wykonywanie na wyrażeniach operacji formalnych, polegających na przekształcaniu wyrażeń w myśl reguł odwołujących się wyłącznie do ich postaci graficznej. Odkrycie, względnie ustanowienie tego rodzaju reguł umożliwiło powstanie i dalszy rozwój dwóch dyscyplin naukowych: matematyki i logiki. Ta ostatnia stała się główną domeną teoretycznej refleksji nad językiem, wyprzedzając pod tym względem językoznawstwo.

W trakcie rozwoju zarówno matematyki, jak i logiki okazało się, że pismo będące po prostu graficzną transkrypcją mowy nie jest dla tych nauk narzędziem optymalnym. Stąd w piśmie zaczynają się pojawiać pewne twory „sztuczne”; w pierwszej kolejności symbole literowe używane jako tzw. zmienne wolne. Umożliwiają one formułowanie twierdzeń ogólnych za pomocą formuł o dowolnie złożonej strukturze, zaś w połączeniu z umownymi znakami działań arytmetycznych tworzą bardzo wygodną notację algebraiczną, bez której dalsze postępy matematyki trudno byłoby sobie wyobrazić. Pojawia się przekonanie, że notacja wzorowana na algebraicznej może być uniwersalna w tym znaczeniu, iż zdolna jest zastąpić język naturalny (przynajmniej w dociekaniach naukowych), przyczyniając się do zasadniczego wzrostu precyzji wypowiedzi i niezawodności rozumowań ${ }^{1}$. Oznaczałoby to zastąpienie języka naturalnego sztucznym językiem symbolicznym.

\footnotetext{
${ }^{1}$ Na pomysł języka czysto symbolicznego wpadł siedemnastowieczny filozof i matematyk G. W. Leibniz. Doszedł on do wniosku, że korzystając z takiego języka, będzie można wszelkie rozumowania zastąpić rachowaniem, czyli prostymi formalnymi operacjami na symbolach, podobnymi do tych, z jakimi mamy do czynienia w arytmetyce. O tym, czy nadzieje Leibniza mogły się spełnić, będzie mowa w wykładzie dziesiątym.
} 
W XIX wieku, w trakcie precyzowania pojęć i twierdzeń analizy matematycznej ${ }^{2}$, okazało się, że notacja algebraiczna wsparta odpowiednimi zwrotami języka naturalnego, nie jest w stanie sprostać potrzebom matematyki. Dokonano wówczas kolejnego wynalazku zmierzającego w kierunku języka czysto symbolicznego - wynalazku kwantyfikatorów. Kwantyfikatory przejmują funkcje występujących we wszystkich językach naturalnych zaimków kwantyfikujących, takich jak: każdy, wszelki, ktokolwiek, żaden, oraz pewien, jakiś, coś, lecz stwarzają znacznie większe możliwości ścisłego formułowania zdań. Właśnie dopiero dzięki zastosowaniu kwantyfikatorów udało się uzyskać ścisłe definicje pojęć granicy i ciągłości funkcji i nie budzące wątpliwości sformułowania szeregu twierdzeń analizy, jak również geometrii.

Kwantyfikatory należą do obszerniejszego gatunku operatorów wiążacych zmienne, do których zaliczamy również matematyczne operatory sumy $\sum_{n=1}^{\infty}$ i iloczynu $\prod_{n=1}^{\infty}$. Wprowadzenie kwantyfikatorów otwarło drogę do języka symbolicznego, w którym istotnie można sformułować dowolną teorię matematyczną. Język taki ukształtował się ostatecznie w matematycznej szkole Davida Hilberta (1862-1943) i nosi nazwę języka rachunku kwantyfikatorów ${ }^{3}$.

Chociaż matematycy współcześnie często posługują się kwantyfikatorami, czy to w wersji symbolicznej: $\forall_{x}, \exists_{x}$ czy w postaci zwrotów: dla dowolnego $x \ldots$, istnieje takie $x$, że..., to jednak w praktyce rzadko posługują się wspomnianym językiem symbolicznym. Bo też język ten nie został pomyślany jako język roboczy matematyków. Miał on raczej stanowić narzędzie skrupulatnej kontroli poprawności dowodów matematycznych, a przede wszystkim — miał służyć refleksji nad matematyka, która to refleksja miała dzięki niemu przybrać postać teorii dorównującej ścisłością teoriom matematycznym, a nawet przewyższającą je pod tym względem. Na gruncie tej teorii, nazwanej metamatematyka, należało - w myśl programu Hilberta — przeprowadzić formalizację istniejących teorii matematycznych przez sformułowanie ich w języku symbolicznym po to, aby posługując się odpowiednio sprecyzowanym pojęciem dowodu, można było w sposób nie budzący wątpliwości rozstrzygać o ich niesprzeczności i zupełności $i^{4}$.

Z dociekań metamatematycznych prowadzonych w szkole Hilberta, a także z wcześniejszych i późniejszych prac logików ${ }^{5}$, wyrosła teoria języków i teorii sformalizowanych. Języki sformalizowane, a jest ich współcześnie wiele, są daleko idącą idealizacją

\footnotetext{
${ }^{2}$ Chociaż rachunkiem różniczkowym posługiwano się już w XVII w., podstawowe pojęcia analizy nie miały ścisłych definicji, zaś pojęcie ,,wielkości nieskończenie małych”, którym się posługiwano było wewnętrznie sprzeczne.

${ }^{3}$ Używa się również określeń ,,język rachunku predykatów” lub ,,język rachunku funkcyjnego”, przy czym odróżnia się język rzędu pierwszego (którym posługiwał się Hilbert) od języków wyższych rzędów. O znaczeniu tego podziału będzie mowa w wykładzie ósmym.

4 Te dwa pojęcia zostaną wyjaśnione w dalszej części wykładu.

5 W tym również logików polskich: Jana Lukasiewicza (1878-1956), Stanisława Leśniewskiego (1886-1939) i Alfreda Tarskiego (1902-1983).
} 
języków naturalnych, a ściślej pewnych ich fragmentów ${ }^{6}$. Z kolei teorie sformalizowane — to idealizacje teorii mających postać systemu aksjomatycznego. Idealizacja polega tu przede wszystkim na zwiększonych (w stosunku do pierwowzoru) wymaganiach efektywności pojęć charakteryzujących wspomniane języki i teorie. Nawet gdy pewne teorie naukowe nie mają postaci systemu aksjomatycznego, a tym bardziej — postaci teorii sformalizowanej, w filozofii nauki często zakłada się kontrfaktycznie, że taką postać mają. Pozwala to na bardziej ścisłe rozważania o teoriach naukowych, ale za to „oderwane od konkretów”. Podejście takie spotyka się z krytyką ze strony bardziej „realistycznie" nastawionych filozofów. Wyjściem pośrednim jest zadanie sobie trudu formalizacji konkretnych, mniej skomplikowanych teorii naukowych.

Ogólne pojęcie efektywności jest trudne do sprecyzowania; poprzestaniemy zatem na spostrzeżeniu, że istnieją stopnie efektywności, a efektywność w stopniu najwyższym jest rozstrzygalnością. Źródłowe pojęcie rozstrzygalności odnosi się do zbioru jednorodnych zagadnień i jest pokrewne pojęciu algorytmu, który — mówiąc swobodnie — stanowi metodę pozwalającą rozstrzygnąć każde z danego zbioru zagadnień, w sposób nie budzący wątpliwości, w skończonej liczbie kroków. Algorytmy w tym szerokim znaczeniu mają zastosowanie $\mathrm{w}$ wielu praktykach eksperymentalnych, na przykład $\mathrm{w}$ chemii i analityce medycznej. Wtórnie, pojęcie rozstrzygalności można stosować do zbiorów, relacji i funkcji przyjmując, że są one rozstrzygalne, gdy rozstrzygalne są — odpowiednio — wszystkie zagadnienia postaci: Czy przedmiot p należy do zbioru $X$ ? Czy przedmiot $p$ pozostaje $w$ relacji $R$ do przedmiotu $q$ ? Czy przedmiot p jest wartościa funkcji $F$ dla argumentu $q$ ? Gdy przedmioty, o które chodzi, są liczbami naturalnymi, zamiast o rozstrzygalności mówi się o obliczalności zbiorów, relacji i funkcji (obliczalny jest np. zbiór liczb pierwszych, a także wszystkie operacje arytmetyczne wykonalne na liczbach naturalnych). Warto tu zauważyć, że również obliczalność, chociaż dotyczy liczb (a zatem przedmiotów wysoce abstrakcyjnych), sprowadza się w istocie do pewnych zabiegów empirycznych: do przekształcania napisów i obserwowaniu rezultatów tych przekształceń. Jednakże obliczalność jest pewną idealizacją rozstrzygalności empirycznej, bowiem dla bardzo dużych liczb nie potrafimy wytworzyć reprezentujących je napisów bądź wykonać wszystkich niezbędnych przekształceń. Pojęcie obliczalności, a w szczególności pojęcie funkcji obliczalnej ma w matematyce ścisłą definicję (definiuje się je przez rekurencję wychodząc od prostych funkcji, których rozstrzygalność nie budzi wątpliwości) ${ }^{7}$.

Kiedy mówimy o językach i teoriach sformalizowanych, pytania o rozstrzygalność dotyczą zbiorów wyrażeń. W praktyce pisemnego komunikowania się ludzi wyrażenia są napisami, których jest zawsze skończenie wiele, a ich liczba zmienia się z dnia na dzień, skoro ciągle przybywa nowych. Dlatego w teorii języka dogodne jest utożsamienie

\footnotetext{
${ }^{6}$ Języki naturalne charakteryzuje tendencja do uniwersalności, co — jak ujawnił Tarski — okupione jest możliwością formułowania w nich tzw. antynomii semantycznych. O jednej z nich będzie mowa w wykładzie siódmym traktującym o pojęciu prawdy.

7 Obszerne i filozoficznie istotne wyjaśnienia dotyczące rozstrzygalności zawiera książka A. G r z eg o r c z y k a, Zagadnienia rozstrzygalności, PWN, Warszawa 1957.
} 
wyrażeń ze skończonymi ciagami (w matematycznym znaczeniu słowa ciąg) utworzonymi z pewnych elementów podstawowych.

Przedstawimy tu bardzo ogólną koncepcję języka sformalizowanego i teorii sformalizowanej, w której pomija się wiele szczegółów. Szczegóły takie stają się istotne wówczas, gdy staramy się opisać konkretny język lub pewien typ języków. Przyjmiemy definicję:

Językiem sformalizowanym nazywamy parę uporządkowaną $\mathrm{L}=\langle\mathrm{A}, L\rangle$, gdzie $\mathrm{A}$ jest niepustym zbiorem skończonym, natomiast $L$ - przeliczalnym i rozstrzygalnym podzbiorem właściwym zbioru wszystkich skończonych ciągów utworzonych z elementów zbioru A. Zbiór A nazywamy alfabetem języka L; zbiór $L$ - zbiorem $z$ dań tego języka.

Występującemu tu, oraz $\mathrm{w}$ innych definicjach, określeniu rozstrzygalny można nadać sens ściśle określony dzięki zastosowanej po raz pierwszy przez Kurta Gödla (1906-1978) metodzie arytmetyzacji języka polegającej na wzajemnie jednoznacznym (i efektywnym) przyporządkowaniu skończonym ciągom symboli liczb naturalnych. Dany zbiór wyrażeń (tj. ciągów) uważa się za rozstrzygalny, gdy zbiór ich „numerów Gödlowskich” jest obliczalny.

Gdy konstruujemy konkretny język sformalizowany, wyznaczenie zbioru zdań tego języka nie jest sprawą prostą zwłaszcza, gdy mamy na względzie późniejszą interpretację tych zdań; musimy wówczas wpierw wyróżnić szereg wyrażeń będących składnikami zdań, odpowiednio je sklasyfikować i ustalić reguły ich wiązania w większe całości.

Aby w danym języku sformalizowanym L skonstruować jakąś teorię sformalizowaną, musimy dysponować rachunkiem logicznym, czyli zbiorem reguł pozwalających ustalić, kiedy pewne zdania są dowodliwe na podstawie innych zdań. Reguły składające się na rachunek logiczny muszą być — jak się często mówi — „czysto formalne”, czyli odwoływać się wyłącznie do kształtu i następstwa symboli, a w żadnym wypadku do intuicyjnego sensu wyrażeń lub wyobrażeń przedmiotów przez te wyrażenia oznaczanych. Reguły rachunku logicznego, zwane regułami dowodzenia dogodnie jest opisywać jako pewnego rodzaju relacje, czyli zbiory par uporządkowanych.

Reguła dowodzenia określoną w języku $\mathrm{L}=\langle\mathrm{A}, L\rangle$ jest dowolny zbiór par postaci $\langle X, A\rangle$, gdzie $X$ jest skończonym podzbiorem zbioru $L$ (a więc zbiorem zdań), natomiast $A$ - elementem zbioru $L$ (pojedynczym zdaniem).

Na przykład, jeśli w alfabecie języka L występuje znak implikacji $\Longrightarrow$, to znaną z elementarnej logiki regułę MP (modus ponens) można zdefiniować (jako relację) następująco:

$\langle X, B\rangle \in$ MP wtedy i tylko wtedy, gdy istnieje takie $A \in L$, że $X=\{A \Longrightarrow B, A\}$.

Reguła MP, jak większość reguł przyjętych w językach sformalizowanych, jest bardzo prosta; do nieco bardziej skomplikowanych należą reguły operowania kwantyfikatorami. 
Aby zbiór reguł dowodzenia zasługiwał na miano rachunku logicznego, musi on spełniać pewne wymogi efektywności. Stąd ustala się, że:

Zbiór reguł dowodzenia $\mathrm{R}$ określonych w języku L jest rachunkiem logicznym $\mathrm{w} \mathrm{L}$ wtedy i tylko wtedy, gdy $\mathrm{R}$ jest zbiorem skończonym i każda reguła $R$ należąca do $\mathrm{R}$ jest relacją rozstrzygalną.

Dysponując pojęciem rachunku logicznego możemy wyjaśnić, czym jest teoria sformalizowana.

Para uporządkowana $\mathrm{T}=\langle\mathbf{A}, \mathbf{R}\rangle$ jest teoria sformalizowana $\mathrm{w}$ języku $\mathrm{L}=\langle\mathrm{A}, L\rangle$ wtedy i tylko wtedy, gdy $\mathbf{A}$ jest rozstrzygalnym podzbiorem zbioru $L$, natomiast $\mathbf{R}$ — rachunkiem logicznym w języku L. Elementy zbioru A nazywamy aksjomatami teorii $\mathrm{T}$.

Jak widać, zgodnie z powyższą definicją, teoria jest wyznaczona przez jej aksjomaty i pewien rachunek logiczny. Niekiedy teorię utożsamia się ze zbiorem zdań dowodliwych na podstawie aksjomatów; wówczas ta sama teoria może być nadbudowana nad różnymi zbiorami aksjomatów, w pewnym sensie równoważnych. Takie pojęcie teorii zakłada, że uprzednio sprecyzowaliśmy pojęcie dowodu.

Zakładając, że $\mathrm{L}=\langle\mathrm{A}, L\rangle$ jest językiem sformalizowanym, $\mathrm{R}$ - rachunkiem logicznym w $\mathrm{L}, X-$ dowolnym podzbiorem zbioru $L, A$ oraz $B_{1}, \ldots, B_{n}-$ dowolnymi elementami zbioru $L$, powiemy, że:

Ciąg zdań $\left\langle B_{1}, \ldots, B_{n}\right\rangle$ jest dowodem zdania $A$ na podstawie zdań $X$ według reguł $\mathrm{R}$ wtedy i tylko wtedy, gdy $B_{n}=A$ oraz dla dowolnego $i=1, \ldots, n, B_{i} \in X$ lub istnieje taka reguła $R \in \mathrm{R}$ oraz taka para $\left\langle Y, B_{i}\right\rangle \in R$, że $Y \subset X \cup\left\{B_{1}, \ldots, B_{i-1}\right\}$.

Jest oczywiste, że gdy $\mathrm{T}=\langle\mathbf{A}, \mathbf{R}\rangle$ jest teorią sformalizowaną $\mathrm{w} \mathrm{L}=\langle\mathrm{A}, L\rangle$, to — zgodnie z przyjętą tu ogólną definicją dowodu - dowodem zdania $A \in L \mathrm{w}$ teorii $\mathrm{T}$ jest taki ciąg $\left\langle B_{1}, \ldots, B_{n}\right\rangle$, który jest dowodem zdania $A$ na podstawie aksjomatów $\mathbf{A}$.

Przyjęte tu założenia dotyczące reguł rachunku logicznego i aksjomatów teorii sformalizowanych prowadzą do bardzo istotnego wniosku, że:

I W każdej teorii sformalizowanej zbiór dowodów jest rozstrzygalny.

Wniosku tego nie możemy tu udowodnić w sposób ścisły, ponieważ nie przyjęliśmy żadnej ścisłej definicji zbioru rozstrzygalnego, jednakże pamiętając, że ciąg zdań jest dowodem, gdy jest dowodem swojego ostatniego elementu, można przekonująco wykazać, że wszystkie pytania postaci:

Czy ciag $\left\langle B_{1}, \ldots, B_{n}\right\rangle$ jest dowodem $w$ teorii $\mathrm{T}$ ? 
mogą być rozstrzygane w sposób systematyczny zgodnie z ustaloną procedurą stawiania pytań. Po prostu pod adresem każdego ze zdań $B_{1}, \ldots, B_{n}$ stawiamy - poczynając od $B_{1}$ - pytanie: czy $B_{i}$ należy do zbioru aksjomatów $\mathbf{A}$ ? W przypadku odpowiedzi twierdzącej przechodzimy z tym samym pytaniem do zdania $B_{i+1}$; gdy odpowiedź jest przecząca odwołujemy się do reguł $\mathbf{R}$. Mając na względzie kolejne reguły $R_{k}$, należące do $\mathbf{R}$ (można je uporządkować!) pytamy: czy dla jakiegoś podzbioru $Y$ zbioru $\left\{B_{1}, \ldots, B_{i}\right\}$, $\left\langle Y, B_{i+1}\right\rangle \in R_{k}$ ? I znów przy pierwszej odpowiedzi pozytywnej przechodzimy do następnego zdania, a gdy odpowiedź jest negatywna - do następnej reguły $R_{k+1}$ i stawiamy pytanie analogiczne do poprzedniego. Jeśli na każde takie pytanie dotyczące kolejnych reguł udzielimy odpowiedzi negatywnej, to uzyskamy werdykt negatywny: ciąg $\left\langle B_{1}, \ldots, B_{n}\right\rangle$ nie jest dowodem. Dla uzyskania werdyktu pozytywnego musimy omawianą procedurę kontynuować aż do ostatniego zdania $B_{n}$.

Rozstrzygalność zbioru dowodów oznacza, że formalizując teorie matematyczne zapewniamy sobie teoretyczną możliwość „,mechanicznego” sprawdzania poprawności dostarczonych dowodów bez odwoływania się do ,intuicji matematycznej” tj. do subiektywnego poczucia trafności przeprowadzonych rozumowań. Ustalmy, że:

Twierdzeniem danej teorii T sformalizowanej w języku $\mathrm{L}=\langle\mathrm{A}, L\rangle$ jest każde i tylko takie zdanie $A \in L$, które ma dowód w teorii T.

(W tym miejscu warto zauważyć, że — w myśl przyjętej definicji dowodu — również aksjomaty teorii mają dowód, który w tym przypadku jest ciągiem jednoelementowym. Aksjomaty są zatem zarazem twierdzeniami teorii.)

Nasuwa się pytanie, czy przyjęte tu określenia dowodu i teorii sformalizowanej nie wskazują jakiejś uniwersalnej metody efektywnego rozstrzygania wszelkich pytań typu:

\section{Czy zdanie A jest twierdzeniem teorii $\mathrm{T}$ ?}

Gdyby taka metoda istniała, to zbiór twierdzeń dowolnej teorii sformalizowanej byłby rozstrzygalny, a tym samym istniałaby metoda mechanicznego dowodzenia twierdzeń uwalniająca matematyków od tej uciążliwej czynności (oczywiście pod warunkiem uprzedniej formalizacji wszystkich teorii matematycznych). W rzeczywistości, tylko w nielicznych teoriach zbiór twierdzeń bywa rozstrzygalny, natomiast w każdej teorii sformalizowanej zbiór jej twierdzeń ma własność zwaną rekurencyjna przeliczalnością. Jeżeli pewien zbiór $X$ jest rozstrzygalny, to o jego podzbiorze $Y$ powiemy, że jest rekurencyjnie przeliczalny, gdy dysponujemy metodą, która o każdym przedmiocie $p$ należącym do $X$ pozwala rozstrzygnąć, czy należy on jednocześnie do $Y$ przynajmniej wtedy, gdy $p$ rzeczywiście należy do $Y$. Rekurencyjna przeliczalność jest więc w istocie „połowiczną rozstrzygalnością", a więc jakby niższym stopniem efektywności.

Pytanie, czy A jest twierdzeniem teorii T? jest równoważne pytaniu, czy A ma dowód $w$ teorii T? Aby na nie odpowiedzieć, nie odwołując się do tajemniczych uzdolnień, które wskazałyby nam właściwą postać poszukiwanego dowodu, nie mamy innej drogi, 
jak dokonać przeglądu wszystkich ciągów skończonych zbudowanych ze zdań języka teorii T, które kończą się zdaniem $A$. Zbiór takich ciągów jest nieskończony, ale przeliczalny i — jak łatwo zauważyć — rozstrzygalny. Ponadto można go ściśle uporządkować, dzieląc na klasy według długości, zaś wewnątrz każdej klasy ciągów o tej samej długości ustalając porządek leksykograficzny (taki jak w słownikach). Jeżeli zdanie $A$ jest rzeczywiście twierdzeniem teorii T, to któryś z analizowanych kolejno ciągów okaże się jego dowodem; natomiast, jeśli zdanie $A$ nie jest twierdzeniem, moglibyśmy to ustalić dopiero po wyczerpaniu wszystkich rozważanych ciągów, co jest niewykonalne.

Wywód ten ujawnia, że nie mamy podstaw, aby utrzymywać, że zbiór twierdzeń teorii sformalizowanej musi być rozstrzygalny, natomiast są podstawy, by twierdzić, że:

I Zbiór twierdzeń dowolnej teorii sformalizowanej jest rekurencyjnie przeliczalny.

Pionierzy formalizacji marzyli o tym, aby przez odpowiedni dobór aksjomatów i reguł dowodzenia zapewnić możliwość bezbłędnego rozstrzygania wszystkich zagadnień, jakie dają się sformułować w języku danej teorii. Nadzieje te okazały się płonne, co wykazały odkrycia Gödla, o których będzie mowa w wykładzie dziesiątym. Poza pewnymi wyjątkami o niewielkim dla matematyki znaczeniu, rekurencyjna przeliczalność zbioru twierdzeń stanowi maksimum tego, co formalizacja jest w stanie zapewnić. Praktyczny pożytek wynikający z formalizacji języków i teorii polega na tym, że dostarcza narzędzia ścisłej kontroli dowodów. Jednakże — jak już zauważyliśmy — głównym jej zadaniem jest zapewnienie należytej ścisłości refleksji nad teoriami. Wiele własności przypisywanych teoriom, a interesujących z poznawczego punktu widzenia, daje się ściśle sprecyzować tylko w odniesieniu do teorii sformalizowanych. Własnościami takimi są, wspomniane już wcześniej, niesprzeczność i zupełność teorii.

Oba te określenia mają pewien ustalony sens intuicyjny. Wiadomo, że teoria jest niesprzeczna, jeśli z jej aksjomatów nie wynikają zdania sprzeczne, czyli takie, z których jedno jest zaprzeczeniem drugiego. $Z$ kolei teoria zupełna to taka, w której w przypadku dowolnego zdania $A$, które daje się sformułować w języku teorii, z jej aksjomatów wynika albo zdanie $A$, albo jego zaprzeczenie.

Wyjaśnienia powyższe nie są w pełni zadowalające, ponieważ nie wyjaśniliśmy wcześniej, co to znaczy wynika, a nawet jeśli założymy, że wynikanie jest tym samym co dowodliwość ${ }^{8}$, pozostaje problem jak rozumieć zaprzeczenie zdania. Utrzymując, że poprzedzając zdanie $A$ znakiem $\neg$ (lub jakimś innym), który mamy zwyczaj czytać nie jest tak, że...tworzymy zaprzeczenie (negację) zdania $A$, odwołujemy się do znaczenia symbolu $\neg$, a nie do jego kształtu. Czy wynika stąd, że nie mamy ogólnego i „formalnego” pojęcia negacji? Owszem, mamy takie pojęcie, a można je zdefiniować odwołując się do konkretnego rachunku logicznego.

\footnotetext{
${ }^{8}$ Co wcale nie jest oczywiste, skoro dowód — zgodnie z przyjętą definicją tego pojęcia — może opierać się na zupełnie dowolnym zestawie reguł formalnych spełniających warunki efektywności.
} 
Załóżmy, że dla dowolnego zdania $A$ języka $\mathrm{L}=\langle\mathrm{A}, L\rangle, \neg A$ jest również zdaniem tego języka, zaś $\mathbf{R}$ jest rachunkiem logicznym w L. Posługując się wygodnym skrótem $X \vdash_{R} A$ zamiast ,istnieje dowód zdania $A$ na podstawie zdań $X$ według reguł rachunku R", możemy wyjaśnić, że:

Zdanie $\neg A$ jest zaprzeczeniem (negacją) zdania $A$, a znak $\neg$ jest znakiem negacji, wówczas, gdy dla dowolnego zbioru zdań $X \subset L, X \vdash_{R} A$ wtedy i tylko wtedy, gdy dla dowolnego zdania $B \in L, X \cup\{\neg A\} \vdash_{R} B$.

Charakteryzując w ten sposób negację odwołujemy się do intuicji, która mówi nam, iż z pary zdań sprzecznych (zdania $A$ i jego negacji $\neg A$ ) wynika dowolne zdanie.

$\mathrm{O}$ teorii $\mathrm{T}=\langle\mathbf{A}, \mathbf{R}\rangle$ sformalizowanej $\mathrm{w}$ języku $\mathrm{L}=\langle\mathrm{A}, L\rangle$ powiemy, że jest niesprzeczna, gdy nie istnieje takie zdanie $B \in L$, że $\mathbf{A} \vdash_{R} B$ i zarazem $\mathbf{A} \vdash_{R} \neg B$. $\mathrm{W}$ przeciwnym przypadku powiemy, że teoria $\mathrm{T}$ jest sprzeczna.

$\mathrm{O}$ teorii $\mathrm{T}=\langle\mathbf{A}, \mathbf{R}\rangle$ sformalizowanej $\mathrm{w}$ języku $\mathrm{L}=\langle\mathrm{A}, L\rangle$ powiemy, że jest zupetna, gdy dla dowolnego zdania $B \in L, \mathbf{A} \vdash_{R} B$ lub $\mathbf{A} \vdash_{R} \neg B$. W przeciwnym przypadku powiemy, że teoria $\mathrm{T}$ jest niezupetna.

Definicje te mają zastosowanie tylko w odniesieniu do teorii, w których języku występuje znak negacji. Jednakże pojęciom niesprzeczności i zupełności możemy nadać również znaczenie ogólniejsze, które pozwala stosować te pojęcia również do teorii, w których języku nie ma negacji. Mówimy wówczas, że teoria $\mathrm{T}=\langle\mathbf{A}, \mathbf{R}\rangle$ jest niesprzeczna, gdy istnieje takie zdanie $B \in L$, dla którego nie zachodzi $\mathbf{A} \vdash_{R} B$, oraz, że jest zupetna, gdy dowolne zdanie $B \in L$, które nie spełnia warunku $\mathbf{A} \vdash_{R} B$, dołączone do aksjomatów A sprawia, że dla dowolnego zdania $C \in L$, zachodzi $\mathbf{A} \cup\{B\} \vdash_{R} C$.

Jak widać, pojęcia niesprzeczności i zupełności można zdefiniować w sposób formalny w odniesieniu do dowolnych teorii sformalizowanych, niezależnie od tego, jakim posługują się rachunkiem logicznym.

W porównaniu z rzeczywistymi produktami ludzkiej działalności poznawczej, teorie sformalizowane są tworami idealnymi w tym samym znaczeniu, w jakim w fizyce gaz doskonały lub jednorodne pole grawitacyjne są idealnymi odpowiednikami realnych gazów i pól. Zatem badając takie twory idealne zamiast teorii „realnych”, filozofia nauki nie oddala się zbytnio od metod stosowanych w matematyce i zaawansowanych naukach empirycznych. 


\section{Wykład szósty}

\section{WYPROWADZALNOŚĆ A WYNIKANIE LOGICZNE}

Wybór symboli składających się na alfabet języka sformalizowanego jest sprawą swobodnej decyzji, chociaż praktyka dowodzi, że pewne notacje są bardziej wygodne od innych. Bardziej niż kształt i układ poszczególnych symboli istotna jest funkcja, jaką pełnią one w budowie zdań i w rachunku logicznym. Ponieważ zdań w każdym języku sformalizowanym jest nieskończenie wiele, ważną rolę pełnią tu spójniki pozwalające tworzyć zdania złożone ze zdań prostych. Oczywiście nie zawsze proces konstruowania zdań przebiega $\mathrm{w}$ tak prosty sposób; często - podobnie jak w językach naturalnych — zdania złożone tworzy się tu z wyrażeń pochodnych względem zdań, lecz nie będących zdaniami. Z punktu widzenia składni, tj. reguł konstruowania zdań, pomiędzy różnymi spójnikami nie ma różnic istotnych; różnice takie ujawnia dopiero dołączony do języka rachunek logiczny.

Wybór rachunku logicznego jest też w pewnej mierze sprawą arbitralnej decyzji, czemu w swoim czasie przypisano rangę zagadnienia filozoficznego, związanego z ogólniejszym problemem roli konwencji w nauce. Świadectwem tego jest słynna zasada tolerancji Rudolfa Carnapa (1891-1970):

W logice nie ma moralności. Każdy ma prawo budować własną logikę, tj. własną formę języka, tak jak sobie życzy. Jedyne, czego się od niego wymaga, to to, by sformułował jasno stosowane przez siebie metody i podał reguły syntaktyczne zamiast argumentów filozoficznych ${ }^{1}$.

Rachunek logiczny jest dowolnym skończonym zbiorem reguł dowodzenia i w każdym języku można ,zainstalować” wiele takich rachunków. Różnice między nimi są mało istotne, gdy różnym rachunkom odpowiada ta sama relacja wyprowadzalności. Mając na względzie zdania ustalonego języka L, mówimy, że:

Zdanie $A$ jest wyprowadzalne ze zbioru zdań $X$ (według reguł R) (symbolicznie: $X \vdash_{R} A$ ) wtedy i tylko wtedy, gdy istnieje dowód zdania $A$ na podstawie zdań $X$ (według reguł $\mathbf{R}$ ).

\footnotetext{
1 Sformułowana przezeń w dziele Logische Syntax der Sprache (1931), które odegrało istotną rolę w rozwoju logicznej teorii języka. Cytuję wg przekładu polskiego B. S t a n o s z, Logiczna składnia języka, PWN, Warszawa 1995, s. 79.
} 
W praktyce, rachunki logiczne uważamy za „różne logiki” tylko wtedy, gdy odpowiadają im różne relacje wyprowadzalności.

Odwołując się do relacji wyprowadzalności, możemy charakteryzować role poszczególnych wyrażeń i identyfikować symbole jako pełniące tę samą rolę w różnych rachunkach, niezależnie od ich postaci graficznej. Jeśli — na przykład — w języku L mamy spójniki $\wedge \mathrm{i} \Longrightarrow$, a relacja wyprowadzalności ma własności następujące:

$$
\begin{aligned}
& \{A, B\} \vdash_{R} A \wedge B,\{A \wedge B\} \vdash_{R} A,\{A \wedge B\} \vdash_{R} B, \\
& \{A \Longrightarrow B, A\} \vdash_{R} B, \text { jeżeli } X \cup\{A\} \vdash_{R} B, \text { to } X \vdash_{R} A \Longrightarrow B,
\end{aligned}
$$

to symbole $\wedge \mathrm{i} \Longrightarrow$ identyfikujemy, kolejno, jako znak koniunkcji i znak implikacji, czyli jako odpowiedniki spójników takich jak ,i” oraz ,jeżeli..., to” występujących w językach naturalnych.

Z definicji pojęcia dowodu przytoczonej w poprzednim wykładzie wynika, że wszystkie relacje wyprowadzalności mają pewne charakterystyczne własności, a mianowicie:

(1) zwrotność: jeżeli $A \in X$, to $X \vdash_{R} A$,

(2) monotoniczność: jeżeli $X \subseteq Y$, to dla dowolnego $A$, jeśli $X \vdash_{R} A$, to $Y \vdash_{R} A$,

(3) przechodniość: jeżeli $\left\{B: X \vdash_{R} B\right\} \vdash_{R} A$, to $X \vdash_{R} A$,

(4) finitystyczność: jeżeli $X \vdash_{R} A$, to istnieje taki skończony zbiór $Y \subseteq X$, że $Y \vdash_{R} A$.

Zdania wyprowadzalne z danego zbioru zdań $X$ nazywa się jego konsekwencjami, a zbiór tych zdań oznacza symbolem $\mathrm{Cn}_{\mathrm{R}}(X)$. Znak $\mathrm{Cn}_{\mathrm{R}}$ nie oznacza relacji, lecz operację na zbiorach zdań. Zachodzi oczywiście równość:

$$
\mathrm{Cn}_{\mathrm{R}}(X)=\left\{B: X \vdash_{R} B\right\}
$$

co pozwala przedstawione powyżej warunki (1)-(4) zredagować następująco:

(1') zwrotność: $X \subseteq \mathrm{Cn}_{\mathrm{R}}(X)$,

(2') monotoniczność: jeżeli $X \subseteq Y$, to $\mathrm{Cn}_{\mathrm{R}}(X) \subseteq \mathrm{Cn}_{\mathrm{R}}(Y)$,

(3') przechodniość: $\mathrm{Cn}_{\mathrm{R}}\left(\mathrm{Cn}_{\mathrm{R}}(X)\right) \subseteq \mathrm{Cn}_{\mathrm{R}}(X)$,

(4') finitystyczność: jeżeli $A \in \mathrm{Cn}_{\mathrm{R}}(X)$, to istnieje taki skończony zbiór $Y \subseteq X$, że $A \in \mathrm{Cn}_{\mathrm{R}}(Y)$.

Swoboda wyboru języka sformalizowanego i rachunku logicznego, o której mówił Carnap, jest w dużym stopniu ograniczona, gdy celem naszym jest formalizacja jakiejś „roboczej wersji” pewnej teorii matematycznej. Musimy wówczas wybrać język, na który teoria ta daje się przełożyć lub — mówiąc ostrożniej — w którym da się możliwie adekwatnie sparafrazować. Wybierając rachunek logiczny, nie musimy dobierać reguł dowodzenia odpowiadających ściśle praktykowanym przez matematyków krokom dowodowym; wystarczy jeśli zostanie odwzorowana odpowiadająca im relacja wyprowadzalności. Nasuwa się pytanie: dlaczego mielibyśmy tę relację odwzorowywać? Innymi 
słowy: dlaczego rachunek logiczny w języku sformalizowanym ma odpowiadać naszej „logice praktycznej” manifestującej się w intuicyjnym doborze kroków dowodowych? Odpowiedzi, że właśnie takie a nie inne kroki dowodowe są dla nas przekonujące, zapewne nie uznalibyśmy za wystarczającą. Rozważmy dwa proste zdania:

(A) Istnieje liczba całkowita mniejsza od każdej liczby całkowitej dodatniej.

(B) Dla każdej liczby całkowitej dodatniej istnieje liczba całkowita od niej mniejsza.

W praktyce dowodzenia chodzi nam niewątpliwie o to, aby na podstawie zdań prawdziwych można było dowodzić tylko zdań prawdziwych. Zdania (A) i (B) oba są prawdziwe, zatem dlaczego skłonni jesteśmy dowodzić (B) na podstawie (A), natomiast odrzucimy dowód (A) na podstawie (B)? Otóż uznajemy poprawność dowodu (B) na podstawie (A) dlatego, że zdanie (B) jest prawdziwe przy każdej możliwej interpretacji występujących tu wyrażeń: liczba całkowita, liczba całkowita dodatnia, mniejsza od, przy której prawdziwe jest również zdanie (A). Gdybyśmy dowodzili (A) na podstawie (B), warunek ten nie byłby spełniony. Można się o tym przekonać dobierając stosowną interpretację wyszczególnionych tu wyrażeń, przy której (B) jest prawdziwe, natomiast (A) fałszywe.

W spostrzeżeniu powyższym zawarta jest idea wynikania logicznego, która była znana już Arystotelesowi. Jak widać pojęcie wynikania logicznego związane jest nieodłącznie z pojęciem prawdy i pojęciem możliwej interpretacji wyrażeń. Jest oczywiste, że zdaniom rozumianym jako pewne struktury graficzne lub ciągi symboli można przypisywać prawdziwość (a także fałszywość) tylko ze względu na określoną, przypisaną im interpretację, ponieważ wraz ze zmianą interpretacji zdanie prawdziwe niekiedy staje się fałszywe. W świetle tego, co powiedzieliśmy o wynikaniu logicznym, aby przekonać się, że wynikanie takie między zdaniami zachodzi, nie wystarczy mieć na względzie tylko ich aktualną interpretację, lecz również wszystkie ich interpretacje możliwe. Tkwi w tym pewna trudność. Gdy posługujemy się językiem naturalnym, ów zasób możliwych interpretacji niełatwo ogarnąć, toteż w praktyce odwołujemy się raczej do tajemniczej ,intuicji logicznej” właściwej każdemu, chociaż w stopniu zróżnicowanym. Zdolny matematyk tym się wśród zwykłych śmiertelników wyróżnia, że posiada tę intuicję w stopniu niezwykle wysokim. Kiedy posługujemy się językiem sformalizowanym, z pomocą przychodzi nam znajomość rachunku logicznego „dopasowanego” do wynikania logicznego.

Charakteryzując języki i teorie sformalizowane, nie zajmowaliśmy się tym, jak występujące w nich zdania mogą być interpretowane. Dlatego właśnie mówiliśmy o wyprowadzalności (którą można zdefiniować za pomocą rachunku logicznego), a nie o wynikaniu logicznym. Języki sformalizowane to języki niezinterpretowane; interpretacja jest czymś, co musi im być nadane z zewnątrz. Dowodzenie twierdzeń w języku niezinterpretowanym nie jest rozumowaniem (w psychologicznym tego słowa znaczeniu), nie wymaga odwoływania się do ,intuicji logicznej”, jest tylko grą przebiegającą według ustalonych reguł, porównywalną do jednoosobowych gier będących rozrywką.

Aby pojęcie wynikania logicznego mogło być zastosowane do zdań języka sformalizowanego, należy zatem określić pełny zasób dopuszczalnych interpretacji tych zdań. 
Chodzi tu o interpretację globalną wszystkich zdań danego języka, co pozwala mówić po prostu o interpretacji języka. Na czym taka interpretacja ma polegać, trudno wyjaśnić, mając na względzie wszystkie możliwe języki sformalizowane i dysponując tylko bardzo ogólną i abstrakcyjną charakterystyką języka, jaką przedstawiliśmy w poprzednim wykładzie. Mechanizm interpretacji pewnej konkretnej klasy języków sformalizowanych przedstawimy w jednym z następnych wykładów. Tutaj ograniczymy się do uwagi, że aby zinterpretować wszystkie zdania danego języka (których jest nieskończenie wiele), należy zastosować znaną w matematyce metodę rekurencji, wychodząc od zdań prostych, a ściślej — od elementarnych znaczących składników tych zdań i mając na względzie operacje prowadzące do wyrażeń coraz bardziej złożonych. Zdanie w określony sposób zinterpretowane jest, przy danej interpretacji, bądź prawdziwe, bądź fałszywe, dlatego, z chwilą, gdy interpretacja wszystkich zdań jest ustalona, dana jest pewna funkcja Val (funkcja waluacji, czyli wartościowania zdań), która każdemu zdaniu danego języka przyporządkowuje, ze względu na daną interpretację, jego wartość logiczną (prawdy bądź fałszu).

Oznaczmy zbiór wszystkich dopuszczalnych interpretacji danego języka L symbolem I (nie troszcząc się na razie o to, czym są owe interpretacje). Oznaczając — jak to jest w zwyczaju — prawdę jedynką a fałsz zerem, zauważymy, że formuła $\operatorname{Val}_{I}(A)=1$ stwierdza, że zdanie $A$ jest prawdziwe przy interpretacji $I \in \mathbf{I}$, natomiast formuła $\operatorname{Val}_{I}(A)=0$ — że zdanie $A$ jest przy tej interpretacji fałszywe. Interpretację, przy której zdanie $A$ (lub każde zdanie należące do zbioru $X$ ) jest prawdziwe zwykło się nazywać modelem zdania $A$ (zbioru zdań $X$ ). Zbiór wszystkich modeli zdania $A$ i zbiór wszystkich modeli zbioru zdań $X$ możemy zdefiniować następująco:

$$
\begin{aligned}
& \operatorname{Mod}(A)=\left\{I \in \mathbf{I}: \operatorname{Val}_{I}(A)=1\right\} \\
& \operatorname{Mod}(X)=\{I \in \mathbf{I}: \text { dla dowolnego } A \in X, I \in \operatorname{Mod}(A)\} .
\end{aligned}
$$

Korzystając z wprowadzonych oznaczeń, można pojęcie wynikania logicznego zdefiniować następująco:

Zdanie $A$ wynika logicznie ze zdań $X$ wtedy i tylko wtedy, gdy $\operatorname{Mod}(X) \subseteq \operatorname{Mod}(A)$, (czyli gdy zdanie $A$ jest prawdziwe przy każdej dopuszczalnej interpretacji, przy której prawdziwe są wszystkie zdania należące do $X$ ).

Pojęcie wyprowadzalności, ponieważ definiowane jest w terminach odnoszących się wyłącznie do struktury wyrażeń, jest pojęciem formalnym, natomiast pojęcie wynikania logicznego, ponieważ odwołuje się do interpretacji wyrażeń, jest pojęciem semantycznym. Z uwagi na to, czego — jak zauważyliśmy wcześniej — oczekujemy od dowodów, pojęcie wynikania jest w pewnym sensie ważniejsze. Pojęcie wyprowadzalności jest bowiem o tyle interesujące, o ile pokrywa się zakresowo z pojęciem wynikania. Dostarcza nam wówczas kryteriów, pozwalających stwierdzić w sposób bardziej bezpośredni i niezawodny, że wynikanie zachodzi. Pytanie, czy te dwa pojęcia: wyprowadzalności i wynikania 
logicznego pokrywają się — odnośnie do pewnego języka i rachunku — zwane jest zagadnieniem petności danego rachunku logicznego.

Języki sformalizowane konstruowane przez logików tworzone są zazwyczaj według podobnego schematu, chociaż różnią się zasobem wyrażeń i form składniowych. Stąd mówi się o standardowej formalizacji lub językach standardowo sformalizowanych. Jak już zauważyliśmy, w danym języku sformalizowanym może „działać” wiele rachunków logicznych. Zasób możliwych interpretacji danego języka również można zdefiniować rozmaicie. W badaniach logicznych często punktem wyjścia jest rachunek (niekiedy bardzo „wymyślny”), określający właściwą mu relację wyprowadzalności. Jeśli relacja ta okaże się z pewnych względów interesująca (na przykład odpowiada pewnym rozumowaniom przeprowadzanym w języku naturalnym), logicy poszukują dla niej odpowiedniej „semantyki”, czyli klasy możliwych interpretacji, która pozwoli zdefiniować relację wynikania logicznego pokrywającą się z daną relacją wyprowadzalności. Bywa również odwrotnie. Dany jest wówczas język sformalizowany i klasa jego możliwych interpretacji uchodzących za „naturalne”, czyli zgodne z interpretacjami pewnych fragmentów języka naturalnego. W tej sytuacji dana jest również relacja wynikania logicznego w owym języku. Zadaniem logiki jest wówczas skonstruować taki rachunek logiczny, aby związana z nim relacja wyprowadzalności pokryła się z daną relacją wynikania. Okazało się — co jest zaskakującym i ważnym odkryciem — że dla pewnych bogatszych języków i pewnych naturalnych ich interpretacji, relacja wyprowadzalności odpowiadająca relacji wynikania logicznego nie istnieje. To jedno z poważniejszych ograniczeń, jakim podlega formalizacja języków i teorii. O ograniczeniach tych będzie mowa w wykładzie dziesiątym. 



\section{Wykład siódmy}

\section{PRAWDA}

W całej tradycji filozoficznej pojęcie prawdy było centralnym, a zarazem bardzo kłopotliwym pojęciem epistemologii (teorii poznania). Fakt, że pojęcie prawdy (i przeciwstawne mu pojęcie fałszu) zawsze budziło zainteresowanie, nie powinien dziwić — wydaje się ono niezbędne we wszystkich formach życia społecznego. W codziennej komunikacji służącej celom praktycznym oczekujemy, że dostarczane nam informacje będą prawdziwe, ponieważ informacje fałszywe uważamy za bezużyteczne a nawet szkodliwe. Wymiar sprawiedliwości żąda od nas, abyśmy mówili ,,prawdę i tylko prawdę”. Również w nauce zmierzamy — jak się zdaje — do tego, by proponowane teorie były prawdziwe.

Trudności związane z pojęciem prawdy są różnego rodzaju. Po pierwsze, pojęcie to jest trudne do sprecyzowania i w przeszłości filozofowie zadowalali się wyjaśnieniami ogólnikowymi i metaforycznymi, czemu sprzyjał rzeczownikowy charakter terminu prawda ${ }^{1}$. W istocie chodziło przecież o to, aby wyjaśnić, do czego się stosuje i jaki sens ma przymiotnik prawdziwy. Przymiotnik prawdziwy w sensie epistemologicznym ${ }^{2}$ używany jest w odniesieniu do przekonań (rozumianych jako stany umysłu), do sądów (będących pewnymi obiektami abstrakcyjnymi, których wyrazem mogą być zdania pewnego języka), bądź wreszcie do samych zdań. Wybór każdego z tych odniesień nastręcza pewne, w każdym przypadku inne, problemy. Po drugie, nawet gdybyśmy wiedzieli, na czym polega prawdziwość, użyteczność tego pojęcia można zakwestionować, utrzymując, że nie dysponujemy kryterium prawdy, czyli jakąś mniej lub bardziej ogólną metodą rozstrzygania, co jest prawdą, a co fałszem ${ }^{3}$. Po trzecie, swobodne posługiwanie się pojęciem

\footnotetext{
${ }^{1}$ Sugerujący, że jest to jakiś przedmiot lub stan rzeczy, do którego można zmierzać. Jeszcze twórca nowoczesnej logiki Gottlob Frege (1848-1925) utrzymywał, że pojęcie prawdy jest niedefiniowalne i postulował istnienie dwu przedmiotów oznaczanych terminami Prawda i Fałsz, będących przedmiotowymi odpowiednikami zdań oznajmujących.

2 Niektórzy filozofowie, kontynuując tradycję scholastyczną, posługują się określeniem prawdziwy w sensie ontologicznym. Prawdziwość w tym sensie ma być atrybutem przysługującym wszystkiemu, co istnieje.

3 Spory o to, co może stanowić kryterium prawdy w różnych naukach (w szczególności w matematyce), czy kryterium takie istnieje i czy może być niezawodne, trwają od starożytności. Już wówczas sceptycy przedstawili trudną do odparcia argumentację, że kryterium takie nie istnieje, a nawet gdyby istniało, nie dałoby się zastosować.
} 
prawdy rodzi antynomie, tj. pozwala z niekwestionowanych przesłanek wyprowadzić dwa zdania sprzeczne. Najstarsza z nich, zwana antynomią Eubulidesa przedstawia się następująco (w wersji nieco uwspółcześnionej).

Rozważmy zdanie: Teraz mówię nieprawdę. Nie jest to (przynajmniej na pozór) zdanie pozbawione sensu, a zatem powinno być prawdziwe bądź nieprawdziwe. Jednakże założenie, że jest ono prawdziwe, prowadzi do wniosku, że jest nieprawdziwe, a założenie, że jest nieprawdziwe - do wniosku, że jest prawdziwe. Wynika stąd, że jest to zdanie zarazem prawdziwe i nieprawdziwe.

Podobnych antynomii można sformułować dowolnie wiele, a jedna z nowszych przedstawia się następująco: Załóżmy, że na jednej stronie kartki napisano zdanie: Zdanie na odwrotnej stronie tej kartki jest fatszywe, natomiast na drugiej stronie tejże kartki zdanie: Zdanie na odwrotnej stronie tej kartki jest prawdziwe. Są to zdania poprawnie zbudowane (z punktu widzenia składni polskiej), a także ich sens zdaje się nie budzić wątpliwości. Tymczasem zakładając jedno z nich, dowodzimy (korzystając z drugiego) czegoś przeciwnego, co oznacza udowodnienie dwóch zdań sprzecznych.

Trudności, o których była mowa powyżej związane są z tzw. klasycznym pojęciem prawdy rozumianym jako „zgodność z rzeczywistością”. Te oraz inne trudności skłaniają pewnych filozofów do zastąpienia klasycznego pojęcia prawdy jakimś innym pojęciem ${ }^{4}$ lub do rezygnacji z pojęcia prawdy w ogóle.

Pierwszą poważną próbę sprecyzowania pojęcia prawdy w odniesieniu do zdań podjął w latach trzydziestych XX wieku polski logik Alfred Tarski ${ }^{5}$. W punkcie wyjścia rozważał on możliwość zdefiniowania wyrażenia zdanie prawdziwe w języku naturalnym, w odniesieniu do zdań tego języka, do którego wyrażenie to należy (na przykład do języka polskiego). Doszedł do wniosku, że skoro zdanie ma być prawdziwe (w sensie klasycznym) wtedy, gdy ,jest tak, jak to zdanie głosi”, to z adekwatnej definicji wyrażenia zdanie prawdziwe powinny wynikać wszystkie równoważności, które można otrzymać ze schematu:

(T) $x$ jest zdaniem prawdziwym wtedy i tylko wtedy, gdy $p$ - przez podstawienie za $p$ konkretnego zdania, a za $x$ - jego nazwy.

Przykładem takiej równoważności jest zdanie:

(1) „Śnieg jest biały” jest zdaniem prawdziwym wtedy i tylko wtedy, gdy śnieg jest biały.

Kłopot z tym, że równoważności takich jest tyle, ile jest zdań w języku, a zatem (teoretycznie) nieskończenie wiele, tymczasem poszukiwana definicja powinna wszystkie takie zdania aksjomatyzować. Tarski pokazał, że w pewnych przypadkach jest to możliwe pod warunkiem, że dysponujemy ścisłą rekurencyjną definicją zbioru zdań

\footnotetext{
${ }^{4}$ Na przykład koherencyjnym pojęciem prawdy jako zgodności z pewnym już uznanym systemem wiedzy lub pragmatycznym pojęciem prawdy przysługującej przekonaniom, których posiadanie jest korzystne.

${ }^{5}$ Przedstawił ją w pracy Pojęcie prawdy w jezykach nauk dedukcyjnych, Warszawskie Towarzystwo Naukowe, Warszawa 1933.
} 
rozważanego języka, jednakże stwierdził również, że w zastosowaniu do zdań języka naturalnego ścisła definicja pojęcia zdania prawdziwego nie jest możliwa przede wszystkim z uwagi na możliwość formułowania w takim języku antynomii semantycznych ${ }^{6}$. Źródłem tych antynomii jest fakt, iż w każdym języku naturalnym można formułować zdania, które mówią coś o wyrażeniach tegoż języka. W większości przypadków jest to nieszkodliwe (np. gdy gramatykę języka polskiego formułuje się w języku polskim), lecz w pewnych przypadkach (gdy mówiąc o wyrażeniach, używamy pojęć semantycznych) umożliwia sformułowanie antynomii.

Jako sposób zapobiegania antynomiom Tarski zaproponował oddzielenie języka przedmiotowego od metajęzyka. Rozróżnienie to jest dziś powszechnie stosowane i odgrywa istotną rolę $\mathrm{w}$ metamatematyce. $\mathrm{W}$ języku przedmiotowym możemy mówić o wszystkim z wyjątkiem wyrażeń tegoż języka i tym, co się z nimi wiąże; istotnym wyposażeniem metajęzyka (który jest nim ze względu na dany język przedmiotowy) jest to wszystko, co pozwala mówić o wyrażeniach danego języka przedmiotowego, jak również o tym, do czego te wyrażenia się odnoszą.

Z dociekań Tarskiego wynikało, że jeśli nie chcemy pozbawiać języków naturalnych ich „naturalnego” charakteru i swoistej uniwersalności (tj. możliwości mówienia za ich pomocą „,o wszystkim”), to ścisła i wolna od sprzeczności definicja zdania prawdziwego może odnosić się wyłącznie do zdań języków sformalizowanych. W słynnej rozprawie z 1933 r. Tarski dostarczył przykładu takiej definicji dla względnie prostego języka sformalizowanego, a także wskazał metodę konstrukcji analogicznej definicji dla języków bardziej skomplikowanych.

Jest oczywiste, że zdanie rozumiane jako napis bądź ciąg symboli może być prawdziwe (względnie fałszywe) tylko wtedy, gdy wiążemy z nim pewną interpretację, którą zazwyczaj nazywamy znaczeniem zdania. Znaczenie przypisujemy też pewnym składnikom zdań, a w przypadku języków sformalizowanych zakładamy, że znaczenie zdania (bądź innego wyrażenia złożonego) jest zdeterminowane przez jego strukturę składniową i znaczenia jego składników elementarnych ${ }^{7}$.

Tarski był świadom tego, że prawdziwość zdania zależy od jego interpretacji, toteż zastrzegał, iż jego definicja stosuje się do języków, w których wyrażenia mają „całkiem konkretne i zrozumiałe dla nas znaczenie”. Jednakże pojęcia znaczenia Tarski nie zdefiniował i jeszcze dziś jest to pojęcie dla teorii języka kłopotliwe. Na szczęście, w przypadku wszystkich interpretacji wyrażeń, które spotykamy w matematyce i naukach przyrodniczych, pojęcie znaczenia może być zastąpione prostszym pojęciem denotacji. Denotacją wyrażenia nazywamy obiekt, do którego wyrażenie to — zgodnie z przyjętą umową — odnosi się. W przypadku języków teorii matematycznych są to — zależnie od rodzaju wyrażeń, które mamy na uwadze - obiekty traktowane jako indywidua, zbiory,

\footnotetext{
${ }^{6}$ Których przykładem jest antynomia Eubulidesa. Antynomie semantyczne wiążą się nie tylko z pojęciem prawdy, lecz również z innymi tzw. pojęciami semantycznymi, charakteryzującymi stosunki między wyrażeniami a przedmiotami, do których się odnoszą.

7 Jest to zasada, pozwalająca przyporządkować znaczenia wszystkim wyrażeniom o dowolnym stopniu złożoności (ale poprawnie zbudowanym), wychodząc od ich składników najprostszych.
} 
relacje bądź funkcje. Możliwość zastąpienia pojęcia znaczenia pojęciem denotacji zachodzi wówczas, gdy wartość logiczna zdań (tj. ich prawdziwość względnie fałszywość) zależy wyłącznie od denotacji elementarnych składników zdań. Oznacza to, że wartość logiczna zdania nie zmieni się, ilekroć zastąpimy w nim jakieś wyrażenie innym, ale o tej samej denotacji. Tożsamość znaczenia nie jest tu wymagana. (Znaczenie to coś więcej niż denotacja, w tym sensie, że wyrażenia o tej samej denotacji mogą różnić się znaczeniem).

Gdy wartość logiczna wszystkich zdań danego języka zależy wyłącznie od denotacji elementarnych składników tych zdań, to mówimy o interpretacji ekstensjonalnej ${ }^{8}$ tego języka. W takim przypadku nasze przeświadczenie, iż wartość logiczna zdań zależy od ich interpretacji, uzyskuje sens nieco bardziej określony: wartość logiczna zdań zależy wyłacznie od funkcji przyporzq̨dkowującej denotacje elementarnym składnikom zdań. Jednakże stwierdzenie to również nie jest całkiem ścisłe. Na ogół, gdy denotacja pewnego wyrażenia jest zbiorem, musimy wiedzieć, co jest dopełnieniem tego zbioru, a w tym celu musimy wskazać pewien zbiór, który traktujemy jako zbiór pełny (uniwersalny). Jest to absolutnie konieczne, gdy nie wszystkim elementarnym składnikom zdań przypisujemy określone denotacje, lecz niektóre z nich traktujemy jako zmienne, jak to ma miejsce we wszystkich bogatszych językach sformalizowanych. Zmienne nie denotują przedmiotów, lecz reprezentują dowolne elementy zbioru uniwersalnego lub innych zbiorów.

W świetle powyższych uwag, w przypadku interpretacji ekstensjonalnej danego języka wartość logiczna jego zdań zależy od układu:

$$
I=\langle U, \Delta\rangle,
$$

gdzie $U$ jest niepustym zbiorem przedmiotów, które mogą być wartościami zmiennych, natomiast $\Delta$ - funkcją przyporządkowującą denotacje elementarnym składnikom zdań traktowanym jako stałe. Układ taki będziemy nazywali interpretacją danego języka, chociaż częściej mówi się tu o modelu języka. My słowa model będziemy używać tylko w kontekście model zdania (jak również — w sensie pochodnym — w kontekście model teorii). Jak wiemy z poprzedniego wykładu, modelem zdania jest taka interpretacja, przy której zdanie to jest prawdziwe. Nakładając na zbiór $U$ oraz na funkcję $\Delta$ odpowiednie warunki, możemy zdefiniować różne klasy możliwych interpretacji danego języka, co — jak już wiemy — pozwala zdefiniować pojęcie wynikania logicznego.

W tym miejscu warto zastanowić się nad tym, co mamy na myśli, mówiąc, że wartość logiczna zdania zależy od interpretacji; czy zależy w tym sensie, jak energia kinetyczna zależy od prędkości (czyli zmienia się w czasie wraz z prędkością), czy raczej tak, jak prędkość zależy od układu odniesienia. W tym drugim przypadku chodzi — jak wiadomo - o to, że pojęcie prędkości ma charakter względny, tj. wymaga relatywizacji do układu odniesienia. Podobnie jest z pojęciem prawdy (i fałszu); powiedzenie, że pewien ciąg symboli jest po prostu prawdziwy, jest pozbawione sensu, natomiast prawdziwość może mu być przypisana ze względu na pewna interpretację. Pojęcie prawdy orzekane

\footnotetext{
${ }^{8}$ Słowo ekstensja używane jest na ogół jako synonim słowa denotacja.
} 
o zdaniach wymaga więc jakiejś relatywizacji; może to być relatywizacja do interpretacji języka rozumianej tak, jak scharakteryzowaliśmy ją powyżej.

Pojęcie prawdy zrelatywizowane do interpretacji (inaczej: modelu języka) pojawiło się w pracach Tarskiego i jego współpracowników dopiero w latach pięćdziesiątych XX wieku. Natychmiast też stało się ważnym narzędziem badań metamatematycznych w zakresie tzw. teorii modeli ${ }^{9}$. Jak wiadomo, kwestia, która to spośród możliwych interpretacji języka danej teorii matematycznej jest jego interpretacją „właściwą” względnie „,naturalną", nie jest dla matematyka sprawą szczególnie istotną (zdaniem niektórych, w ogóle nie powinno to matematyków interesować). Jedynie w przypadku pewnych teorii (np. arytmetyki) matematycy starają się odróżnić tzw. modele standardowe od pozostałych. Natomiast korzystając z tego, że interpretacje są tworami teoriomnogościowymi, można w metamatematyce badać różne modele i klasy modeli poszczególnych teorii. Pojęcie prawdy zrelatywizowane do interpretacji języka teorii jest $w$ tych badaniach pojęciem kluczowym. Jak takie pojęcie można zdefiniować w odniesieniu do zdań konkretnego języka, pokażemy w następnym wykładzie.

Pojęcie prawdy, które Tarski starał się zdefiniować w rozprawie z 1933 r. miało nieco inny charakter. Było to pojęcie zrelatywizowane do języka, którego wyrażenia mają — jak już cytowaliśmy — „całkiem konkretne i zrozumiałe dla nas znaczenie”. Właśnie wspomniana rozprawa i przedstawiona w niej definicja stała się przedmiotem szczególnego zainteresowania filozofów, tym bardziej, że Tarski nie ukrywał, że jego zamiarem jest sprecyzowanie epistemologicznego pojęcia prawdy. Zdaniem wielu filozofów, definicja ta nie spełnia ich oczekiwań z różnych powodów. Niektórzy pragnęliby zapewne uniknąć wszelkiej relatywizacji pojęcia prawdy, a zatem nie stosować tego pojęcia do tworów językowych takich jak zdania, lecz raczej do abstrakcyjnych „sądów” lub stanów umysłu. Z kolei inni utrzymują, że pojęcie prawdy nie zostało tu należycie wyjaśnione, ponieważ proponowana definicja nie jest ogólna, lecz odnosi się zawsze do konkretnego języka. Wątpliwości budzi też pojęcie języka, którym posługuje się Tarski w nieformalnych komentarzach, nie starając się go sprecyzować. Pojawia się problem, kiedy to z wyrażeniami języka wiążemy „,całkiem konkretne i zrozumiałe dla nas znaczenie” i rodzą się wątpliwości, czy w ogóle jest to możliwe. Te z kolei skłaniają pewnych filozofów do eliminacji pojęcia prawdy z refleksji nad nauką, jako pojęcia, które niczego nie wyjaśnia, i zastąpienia go pojęciem „racjonalnej akceptowalności” hipotez i teorii. Zazwyczaj utrzymują oni, że reguły, które decydują o ich akceptowaniu, są historycznie zmienne. Podejście takie ma jeden podstawowy mankament: nie potrafi wyjaśnić linearnego wzrostu naszej wiedzy, który można wyjaśnić właśnie „zmierzaniem do prawdy”. Oczywiście, pojęcie prawdy występujące w tym kontekście wymaga dalszych analiz.

Użyteczność pojęcia zdania prawdziwego zrelatywizowanego do interpretacji rozumianej tak, jak to przedstawiono powyżej, nie jest kwestionowana, przynajmniej na gruncie metamatematyki. Natomiast jego użyteczność w refleksji nad teoriami z dziedziny nauk empirycznych jest przedmiotem sporu.

\footnotetext{
9 Jest to obecnie najbardziej zaawansowana dziedzina badań metamatematycznych.
} 



\section{Wykład ósmy}

\section{JEZYKI ELEMENTARNE I ICH INTERPRETACJE}

W celu lepszego zrozumienia pojęć i zagadnień omówionych w trzech poprzednich wykładach, przedstawimy tu sformalizowany język pewnej konkretnej teorii matematycznej i zasób jego możliwych interpretacji. Teoria, którą mamy na względzie, to elementarna teoria liczb naturalnych. Będziemy ją nazywać po prostu arytmetyka i oznaczać symbolem AR, natomiast jej język — symbolem $\mathrm{L}_{\mathrm{AR}}$.

Jak wiemy, fundamentem języka sformalizowanego jest jego alfabet. W omawianym przypadku składają się nań przede wszystkim symbole logiczne: $\neg$ (negacji), $\Longrightarrow$ (implikacji), $\wedge$ (koniunkcji), $\vee$ (alternatywy), $\Longleftrightarrow$ (równoważności), = (identyczności), $\forall$ (kwantyfikatora ogólnego), $\exists$ (kwantyfikatora egzystencjalnego). Listę tę uzupełniają znaki swoiście arytmetyczne: $0,<,+, \cdot, \mathrm{S}$ (znak operacji następnika). Skoro w języku $\mathrm{L}_{\mathrm{AR}}$ mamy kwantyfikatory, niezbędna jest również obecność zmiennych

$$
v_{1}, v_{2}, v_{3}, \ldots, v_{n}, \ldots,
$$

które mają być wiązane kwantyfikatorami. Są istotne powody, aby zmiennych takich było nieskończenie wiele ${ }^{1}$. Skoro tak, to nie możemy ich wszystkich zaliczyć do alfabetu, ponieważ ustaliliśmy, że alfabet ma być zbiorem skończonym. Dlatego zmienne musimy uważać za wyrażenia złożone, na przykład z litery $v$ i odpowiedniej liczby apostrofów. Do alfabetu zaliczymy wówczas tylko dwa symbole: literę $v$ i apostrof '. Zmiennymi będą wówczas wyrażenia:

$$
v^{\prime}, v^{\prime}, v^{\prime}, \ldots
$$

W praktyce zamiast wielu apostrofów będziemy oczywiście korzystać z subskryptów liczbowych, jak to uczyniliśmy powyżej. Jak w większości języków sformalizowanych, do alfabetu dodamy jeszcze parę nawiasów (lewostronny i prawostronny), niezbędnych dla zapewnienia strukturalnej jednoznaczności wyrażeń złożonych.

\footnotetext{
${ }^{1}$ Liczba zmiennych występujących w każdym konkretnym wyrażeniu (na przykład zdaniu) jest oczywiście skończona $\mathrm{i}$ - w praktyce — niezbyt duża. Gdybyśmy jednak postanowili, że nie może ona przekraczać określonej liczby $n$, skomplikowalibyśmy pojęcie dowodliwości (wyprowadzalności), ponieważ mogłoby się okazać, że każdy dowód pewnego zdania o $n$ zmiennych wymaga przesłanek o większej liczbie zmiennych.
} 
Wśród symboli składających się na alfabet danego języka wyróżniamy zazwyczaj symbole strukturalne i deskryptywne. Podział ten jest w pewnym stopniu konwencjonalny; najczęściej do strukturalnych zaliczamy nawiasy i symbole logiczne, natomiast do deskryptywnych - symbole specyficzne teorii, którą w danym języku zamierzamy sformułować. Cechą wyróżniającą symboli deskryptywnych jest to, iż przypisujemy im denotacje, natomiast symbole strukturalne mają nam umożliwić odróżnianie od siebie wyrażeń, którym chcemy przypisać różną strukturę, chociaż utworzone są z tych samych symboli deskryptywnych, występujących w tym samym porządku.

Zmierzając do zdefiniowania zbioru zdań języka $\mathrm{L}_{\mathrm{AR}}$, wyjaśnimy wpierw, jakie wyrażenia tego języka są jego formułami nazwowymi. Ustalmy, że:

(i) symbol 0 oraz wszystkie zmienne $v_{1}, \ldots, v_{n}, \ldots$, są formułami nazwowymi,

(ii) jeżeli wyrażenia $\alpha$ i $\beta$ są formułami nazwowymi, to również wyrażenia $\mathrm{S}(a)$, $(\alpha+\beta)$, oraz $(\alpha \cdot \beta)$ są formułami nazwowymi.

Warunki (i) i (ii) tworzą tu tzw. definicję indukcyjną, którą w znany sposób można przerobić na definicję normalną zbioru formuł nazwowych. W podobny sposób charakteryzujemy zbiór formut zdaniowych ${ }^{2}$ :

(i) jeżeli wyrażenia $\alpha$ i $\beta$ są formułami nazwowymi, to wyrażenia $(\alpha<\beta)$ i $(\alpha=\beta)$ są formułami zdaniowymi,

(ii) jeżeli $\alpha$ jest formułą zdaniową, to wyrażenia $\neg(\alpha), \forall v_{i}(\alpha), \exists v_{i}(\alpha)$ są również formułami zdaniowymi,

(iii) jeżeli $\alpha$ i $\beta$ są formułami zdaniowymi, to wyrażenia $(\alpha \Rightarrow \beta),(\alpha \wedge \beta)$, $(\alpha \vee \beta)$ oraz $(\alpha \Longleftrightarrow \beta)$ są również formułami zdaniowymi.

Przedstawione tu wyjaśnienia nie są całkiem ścisłe i wymagają komentarza. Po pierwsze, dotyczą one języka $\mathrm{L}_{\mathrm{AR}}$, ale sformułowane są w jego metajęzyku: litery greckie $\alpha$ i $\beta$ występują tu jako zmienne reprezentujące dowolne wyrażenia języka $\mathrm{L}_{\mathrm{AR}}$. Po drugie, symbole języka $\mathrm{L}_{\mathrm{AR}}$ występują tu $\mathrm{w}$ innej roli niż $\mathrm{w}$ języku $\mathrm{L}_{\mathrm{AR}}$ — są po prostu własnymi nazwami; dlatego np. napis $(\alpha=\beta)$ należy rozumieć jako ,wyrażenie utworzone z następujących po sobie: nawiasu lewostronnego, wyrażenia $\alpha$, znaku $=$, wyrażenia $\beta$ i nawiasu prawostronnego".

Język $\mathrm{L}_{\mathrm{AR}}$ jako język arytmetyki ma pewną „,naturalną” interpretację, chociaż — wbrew potocznemu mniemaniu — nie da się powiedzieć, że jest to interpretacja jednoznacznie określona ${ }^{3}$. Jednakże naszym zadaniem będzie zdefiniowanie nie jakiejś interpre-

\footnotetext{
${ }^{2}$ Pojęcie formuły zdaniowej ma szerszy zakres niż pojęcie zdania; zdaniami nazywamy tu tylko takie formuły zdaniowe, w których nie występują zmienne wolne, czyli nie związane żadnym kwantyfikatorem.

${ }^{3}$ Przy tej naturalnej interpretacji zmienne mają reprezentować liczby naturalne, jednakże na pytanie, jakie to przedmioty są liczbami naturalnymi, można udzielić różnych odpowiedzi, przy czym żadna z nich nie jest bardziej ,naturalna” od pozostałych.
} 
tacji wyróżnionej, lecz klasy możliwych interpretacji języka $\mathrm{L}_{\mathrm{AR}}$. Jak wiemy z poprzedniego wykładu, interpretacją języka sformalizowanego jest układ postaci $I=\langle U, \Delta\rangle$ spełniający określone warunki. Pamiętamy, że $U$ ma tutaj być niepustym zbiorem, natomiast $\Delta$ - funkcją przyporządkowującą elementarnym składnikom zdań ich denotacje. Tymi elementarnymi składnikami są zawsze symbole zaliczane do deskryptywnych, a więc $\mathrm{w}$ przypadku języka $\mathrm{L}_{\mathrm{AR}}$ są to symbole specyficzne arytmetyki, czyli: $0, \mathrm{~S},<$, ,$+ \cdot$ Przypisywane im denotacje są zawsze przedmiotami odpowiedniego typu ${ }^{4}$ określonego relatywnie do zbioru $U$. Wyrażenia, których denotacje są tego samego typu zaliczamy do tej samej kategorii semantycznej. W języku $\mathrm{L}_{\mathrm{AR}}$ mamy do czynienia $\mathrm{z}$ nazwą indywiduową 0 , predykatem dwuargumentowym $<$, funktorem nazwotwórczym jednoargumentowym S i dwoma funktorami nazwotwórczymi dwuargumentowymi $+\mathrm{i} \cdot$. Są to wszystkie kategorie semantyczne wyrażeń, jakie w tym języku występują. W tej sytuacji klasę możliwych interpretacji języka $\mathrm{L}_{\mathrm{AR}}$ charakteryzujemy następująco:

Układ $I=\langle U, \Delta\rangle$ jest możliwą interpretacją języka $\mathrm{L}_{\mathrm{AR}}$ wtedy i tylko wtedy, gdy $U$ jest niepustym zbiorem, natomiast $\Delta$ - funkcją, której dziedziną jest zbiór $\{0, \mathrm{~S}$, $<,+, \cdot\}$, a jej wartości spełniają warunki następujące:

(i) $\Delta(0) \in U$

(ii) $\Delta(<) \in 2^{U \times U}$

(iii) $\Delta(S) \in U^{U}$

(iv) $\Delta(+) \in U^{U \times U}$

(v) $\Delta(\cdot) \in U^{U \times U}$

Wynika stąd, że 0 denotuje zawsze określony element zbioru $U$, znak $<-$ dwuczłonową relację $\mathrm{w}$ tym zbiorze, ponadto $\mathrm{S}-$ jednoargumentową, zaś $+\mathrm{i} \cdot-$ dwuargumentowe funkcje o argumentach i wartościach ze zbioru $U$.

Aby wyjaśnić, kiedy pewna formuła zdaniowa języka $\mathrm{L}_{\mathrm{AR}}$ jest prawdziwa przy danej interpretacji $I$, dogodnie jest wprowadzić wpierw dwa pojęcia pomocnicze: pojęcie waluacji zmiennych i wartości semantycznej wyrażenia przy danej waluacji zmiennych. Waluacją (inaczej: wartościowaniem) zmiennych nazywamy przypisanie wszystkim zmiennym jednocześnie pewnych wartości. W rozważanym przypadku będą to zawsze przedmioty należące do $U$, zatem konkretną waluację zmiennych $v_{1} \ldots, v_{n}, \ldots$ można utożsamić z nieskończonym ciągiem $\mathrm{c}=\left\langle c_{1}, \ldots, c_{n}, \ldots\right\rangle$ utworzonym z elementów $U$.

Ustalmy, że symbolem $\mathrm{c}(i / u)$ oznaczamy ciąg otrzymany z ciągu c przez zastąpienie $i$-tego wyrazu elementem $u$ ze zbioru $U$. Wartość semantyczna wyrażenia jest w pewnym sensie rozszerzeniem pojęcia denotacji na wyrażenia złożone, lecz w przeciwieństwie do denotacji jest zrelatywizowana do waluacji zmiennych. Wartość semantyczną danego

\footnotetext{
${ }^{4}$ Pojęcie typu nawiązuje tu do prostej teorii typów, o której była mowa w wykładzie trzecim. Różnica polega na tym, że typy przedmiotów określamy nie względem zbioru indywiduów, lecz w stosunku do dowolnego, lecz ustalonego niepustego zbioru przedmiotów dowolnych.
} 
wyrażenia $\alpha$ (ze względu na waluację c) oznaczamy symbolem $\mathrm{W}_{\mathrm{c}}(\alpha)$. W przypadku języka $\mathrm{L}_{\mathrm{AR}}$, definicja indukcyjna pojęcia wartości semantycznej przedstawia się następująco:

(i) $\mathrm{W}_{\mathrm{c}}\left(v_{i}\right)=c_{i}$,

(ii) jeżeli $\alpha \in\{0,<, \mathrm{S},+, \cdot\}$, to $\mathrm{W}_{\mathrm{c}}(\alpha)=\Delta(\alpha)$,

(iii) jeżeli $\alpha$ i $\beta$ są formułami nazwowymi, to:

$\mathrm{W}_{\mathrm{c}}(\mathrm{S}(\alpha))=\Delta(S)\left(\mathrm{W}_{\mathrm{c}}(\alpha)\right)$

$\mathrm{W}_{\mathrm{c}}(\alpha+\beta)=\Delta(+)\left(\mathrm{W}_{\mathrm{c}}(\alpha), \mathrm{W}_{\mathrm{c}}(\beta)\right)$,

$\mathrm{W}_{\mathrm{c}}(\alpha \cdot \beta)=\Delta(\cdot)\left(\mathrm{W}_{\mathrm{c}}(\alpha), \mathrm{W}_{\mathrm{c}}(\beta)\right)$,

(iv) jeżeli $\alpha$ i $\beta$ są formułami nazwowymi, to:

$\mathrm{W}_{\mathrm{c}}(\alpha<\beta)=1$ wtedy i tylko wtedy, gdy $\mathrm{W}_{\mathrm{c}}(\alpha) \Delta(<) \mathrm{W}_{\mathrm{c}}(\beta)$,

(v) jeżeli $\alpha$ jest formułą zdaniową, to:

$\mathrm{W}_{\mathrm{c}}(\neg \alpha)=1$ wtedy i tylko wtedy, gdy $\mathrm{W}_{\mathrm{c}}(\alpha)=0$,

$\mathrm{W}_{\mathrm{c}}\left(\forall v_{i}(\alpha)\right)=1$ wtedy i tylko wtedy, gdy dla dowolnego $u \in U, \mathrm{~W}_{\mathrm{c}(i / u)}(\alpha)=1$,

$\mathrm{W}_{\mathrm{c}}\left(\exists v_{i}(\alpha)\right)=1$ wtedy i tylko wtedy, gdy istnieje takie $u \in U, \mathrm{~W}_{\mathrm{c}(i / u)}(\alpha)=1$,

(vi) jeżeli $\alpha$ i $\beta$ są formułami zdaniowymi, to:

$\mathrm{W}_{\mathrm{c}}(\alpha \Longrightarrow \beta)=1$ wtedy i tylko wtedy, $\operatorname{gdy~}_{\mathrm{c}}(\alpha)=0$ lub $\mathrm{W}_{\mathrm{c}}(\beta)=1$,

$\mathrm{W}_{\mathrm{c}}(\alpha \wedge \beta)=1$ wtedy i tylko wtedy, $\operatorname{gdy~}_{\mathrm{c}}(\alpha)=1 \mathrm{i} \mathrm{W}_{\mathrm{c}}(\beta)=1$,

$\mathrm{W}_{\mathrm{c}}(\alpha \vee \beta)=1$ wtedy i tylko wtedy, gdy $\mathrm{W}_{\mathrm{c}}(\alpha)=1$ lub $\mathrm{W}_{\mathrm{c}}(\beta)=1$,

$\mathrm{W}_{\mathrm{c}}(\alpha \Longleftrightarrow \beta)=1$ wtedy i tylko wtedy, gdy $\mathrm{W}_{\mathrm{c}}(\alpha)=1 \mathrm{i} \mathrm{W}_{\mathrm{c}}(\beta)=1$ lub $\mathrm{W}_{\mathrm{c}}(\alpha)=0$ i $\mathrm{W}_{\mathrm{c}}(\beta)=0$.

Przyjęliśmy tu umownie — jak widać — że wartościami semantycznymi formuł zdaniowych są 1 bądź 0, stosowane zazwyczaj jako symbole prawdy i fałszu. Powiemy zatem, że formuła zdaniowa $\alpha$ jest prawdziwa przy wartościowaniu zmiennych c, gdy jej wartość semantyczna przy tym wartościowaniu jest jedynką.

Jednakże pojęcie prawdziwości można uwolnić od relatywizacji do wartościowania zmiennych. Można wykazać, że realna zależność prawdziwości formuły zdaniowej od wartościowania zmiennych zachodzi tylko wtedy, gdy występują w niej tzw. zmienne wolne, ale właśnie wtedy formułę uważamy za prawdziwa (bez relatywizacji), gdy jest prawdziwa przy każdym wartościowaniu zmiennych ${ }^{5}$. Formuły zdaniowe, które nie zawierają zmiennych wolnych, zwane zdaniami domkniętymi lub po prostu zdaniami, są albo prawdziwe przy wszystkich wartościowaniach, albo przy wszystkich fałszywe. Zatem o dowolnych formułach zdaniowych można mówić, że są prawdziwe zawsze i tylko wtedy, gdy są prawdziwe przy wszystkich wartościowaniach zmiennych.

Zdefiniowane powyżej pojęcia: wartościowania zmiennych, wartości semantycznej wyrażeń oraz pochodne w stosunku do nich pojęcie prawdziwości stosują się wyłącznie

\footnotetext{
5 Jest to zgodne z obyczajem przyjętym w matematyce, gdzie kwantyfikatory ogólne poprzedzające całą formułę zdaniową na ogół się pomija i uważa się ją za prawdziwą, gdy jest prawdziwa przy każdym wartościowaniu zmiennych.
} 
do wyrażeń języka $\mathrm{L}_{\mathrm{AR}}$, chociaż pojęcia te mogą być zdefiniowane w podobny sposób w odniesieniu do innych języków sformalizowanych. Zauważmy, że definiując wspomniane pojęcia, odwoływaliśmy się często do zbioru $U$ oraz funkcji $\Delta$, a tym samym do interpretacji $I=\langle U, \Delta\rangle$, co wskazuje na to, że pojęcia te są w istocie zrelatywizowane do możliwych interpretacji języka $\mathrm{L}_{A R}$. Relatywizację tę pomijaliśmy wyłącznie dlatego, aby nie przeciążać i tak już skomplikowanej symboliki. Kiedy uwalniamy się od relatywizacji do wartościowania zmiennych, pozostaje tylko wspomniana powyżej relatywizacja do interpretacji. Pojęcie prawdy, które ostatecznie zdefiniowaliśmy, jest zatem pojęciem prawdziwości zdania (ogólniej: formuły zdaniowej) ze względu na jednq $z$ możliwych interpretacji danego języka, rozumianą jako układ postaci $I=\langle U, \Delta\rangle$.

Kiedy w matematyce mówi się, że jakieś zdanie jest prawdziwe „po prostu” (czyli bez wskazania relatywizacji), chodzi zazwyczaj o prawdziwość ze względu na „standardową” interpretację danego języka. Na przykład gdy mówimy, że zdanie języka $\mathrm{L}_{\mathrm{AR}}$ :

$$
\mathrm{S}(\mathrm{S}(0))+\mathrm{S}(\mathrm{S}(0))=\mathrm{S}(\mathrm{S}(\mathrm{S}(\mathrm{S}(0))))^{6}
$$

jest prawdziwe, to twierdzimy $w$ istocie, że zdanie to jest prawdziwe przy takiej interpretacji języka $\mathrm{L}_{\mathrm{AR}}$, w której 0 denotuje $\varnothing$ (zbiór pusty), natomiast $\mathrm{S}$ - operację następnika zbioru $X$, zdefiniowaną jako $X \cup\{X\}$.

Zdefiniowane jak powyżej pojęcie prawdy jest semantycznym pojęciem prawdy. Utrzymuje się, że ma ono wiele wspólnego z filozoficznym klasycznym pojęciem prawdy i jest wynikiem jego precyzacji. Zdarza się, że pewien matematyk pojmuje pojęcie prawdy inaczej, określając tym mianem zdania, które zostały udowodnione na podstawie aksjomatów jakiejś teorii. Otóż istnienie dowodu oznacza jedynie, że zdanie to wynika logicznie $\mathrm{z}$ aksjomatów danej teorii, a więc jest prawdziwe przy każdej interpretacji języka teorii, przy której prawdziwe są jej aksjomaty. Gdybyśmy oświadczenie wspomnianego matematyka rozumieli dosłownie, oznaczałoby ono, że relatywizuje on pojęcie prawdy do teorii (danej przez zbiór aksjomatów i jakieś reguły dowodzenia). Byłoby to porzucenie klasycznej koncepcji prawdy na rzecz koncepcji koherencjonistycznej (prawda jako zgodność z systemem). Następstwem tego jest odrzucenie metalogicznej zasady wyłączonego środka (głoszącej, że z dwóch zdań sprzecznych jedno jest prawdziwe), ponieważ wszystkie poważniejsze teorie matematyczne są niezupełne, co oznacza, iż pewne zdanie jak również jego negacja nie są twierdzeniami teorii ${ }^{7}$.

W tytule tego wykładu użyliśmy określenia ,,języki elementarne”, które domaga się wyjaśnienia. Określenie to jest dwuznaczne; rozróżnia się języki syntaktycznie elementarne i semantycznie elementarne (jak również syntaktycznie i semantycznie nieelementarne). Język nazywamy syntaktycznie elementarnym, gdy nie występują w nim zmienne

\footnotetext{
${ }^{6}$ Jest to „doniosłe” twierdzenie matematyczne, (często cytowane przez filozofów jako przykład ,prawdy koniecznej”), iż $2+2=4$, bowiem $S(S(0))=2$, zaś $S(S(S(S(0))))=4$.

7 Wynika to z twierdzenia K. Gödla, o którym będzie mowa w wykładzie dziesiątym.
} 
o charakterze predykatów lub funktorów bądź wprawdzie zmienne takie występują, ale nie są wiązane kwantyfikatorami; w przeciwnym przypadku mówimy, że język jest syntaktycznie nieelementarny. Natomiast kwalifikując język jako semantycznie elementarny lub nieelementarny, bierzemy pod uwagę klasę jego możliwych interpretacji. Pojęcia te są bardziej skomplikowane, ponieważ semantyczna nieelementarność może realizować się w różny sposób. Przedstawiony tu język $\mathrm{L}_{\mathrm{AR}}$ jest językiem syntaktycznie elementarnym, jednozakresowym, ponieważ dysponuje jednym rodzajem zmiennych. Jeśli — tak, jak w przedstawionej powyżej konstrukcji — zmienne te mogą reprezentować elementy dowolnego niepustego zbioru $U$, to język ten jest zarazem semantycznie elementarny. Byłby nim również wtedy, gdybyśmy go wyposażyli w zmienne drugiego rodzaju, ale pod warunkiem, że również one reprezentują przedmioty z dowolnego niepustego zbioru $V$, być może różnego od $U$. Natomiast, gdybyśmy ustalili, że zmienne pewnego języka $\mathrm{L}$ reprezentują zawsze nie tylko elementy pewnego zbioru, lecz również wszystkie jego podzbiory, zaś pewien predykat dwuargumentowy $\in$ interpretowali konsekwentnie jako należenie do zbioru, to mielibyśmy do czynienia z językiem wprawdzie nadal syntaktycznie elementarnym, lecz semantycznie nieelementarnym. Podobnie byłoby wtedy, gdybyśmy do znanego nam języka $\mathrm{L}_{\mathrm{AR}}$, którego zmienne reprezentują zawsze elementy dowolnego niepustego zbioru $U$ wprowadzili dodatkowo zmienne reprezentujące dowolne podzbiory zbioru $U$ oraz predykat $\in$ interpretowany stale jako relacja należenia do zbioru. Języki syntaktycznie nieelementarne interpretuje się z reguły w taki sposób, że stają się one zarazem semantycznie nieelementarnymi. Nie wyliczyliśmy tu wszystkich możliwych sytuacji. Ogólnie, lecz niezbyt ściśle, można powiedzieć, że język semantycznie nieelementarny to taki, w którym przy każdej z możliwych interpretacji można wyrazić pewien fragment teorii mnogości lub - innymi słowy — wypowiadać twierdzenia o wszystkich podzbiorach pewnego zbioru.

Jak zobaczymy, elementarny bądź nieelementarny charakter języka ma istotny wpływ na charakter teorii, jakie w danym języku dają się sformułować. Przedstawiony powyżej język $L_{A R}$ jest oczywiście językiem i syntaktycznie i semantycznie elementarnym. 


\section{Wykład dziewiąty}

\section{TEORIE ELEMENTARNE I NIEELEMENTARNE}

Przedstawiony w poprzednim wykładzie sformalizowany język $\mathrm{L}_{\mathrm{AR}}$ jest z przeznaczenia językiem elementarnej teorii liczb naturalnych, którą tu oznaczamy symbolem AR. Ustaliliśmy, że w języku tym zmiennymi są $v_{1}, \ldots, v_{n}, \ldots$ Jednakże do wysłowienia aksjomatów teorii AR potrzeba tylko trzech zmiennych, zatem dla uproszczenia zapisu założymy, że zmiennymi są również litery $x, y, z$. Formułując aksjomaty, przyjmiemy również zwykłe umowy pozwalające ograniczyć liczbę nawiasów. Przy takich ustaleniach aksjomaty teorii AR możemy sformułować następująco:

1. $0<\mathrm{S}(x)$

2. $\mathrm{S}(x)=\mathrm{S}(y) \Longrightarrow x=y$

3. $\neg(x=0) \Longrightarrow \exists y(x=\mathbf{S}(y))$

4. $x<y \Longrightarrow \neg(y<x)$

5. $(x<y \wedge y<z) \Longrightarrow x<z$

6. $x<y \vee y<x \vee x=y$

7. $x<\mathrm{S}(x)$

8. $x<y \Rightarrow \mathrm{S}(x)<\mathrm{S}(y)$

9. $x<\mathrm{S}(y) \Longrightarrow(x=y \vee x<y)$

10. $x+0=x$

11. $x+\mathrm{S}(y)=\mathrm{S}(x+y)$

12. $x<y \Longrightarrow \exists z(z<y \wedge y=x+\mathrm{S}(z))$

13. $x \cdot 0=0$

14. $x \cdot \mathrm{S}(y)=x \cdot y+x$

Aksjomaty te - zgodnie z obyczajem przyjętym w matematyce — zapisane zostały w postaci formuł zdaniowych zawierających zmienne wolne; ich sens oczywiście nie uległby zmianie, gdybyśmy wszystkie te zmienne związali kwantyfikatorami ogólnymi poprzedzającymi całą formułę. Łatwo zauważyć, że znak mniejszości < mógłby tu zostać zdefiniowany za pomocą pozostałych i wówczas wszystkie aksjomaty zawierające ten znak moglibyśmy pominąć. 
Przedstawiona powyżej lista aksjomatów nie jest kompletna. Brak tutaj tak istotnej dla arytmetyki zasady indukcji. Otóż jeśli omawiana teoria ma zmieścić się w syntaktycznie elementarnym języku $\mathrm{L}_{\mathrm{AR}}$ i pozostać teorią elementarną, to zasada indukcji nie da się sformułować w całej ogólności i za pomocą jednej formuły zdaniowej. Zamiast jednego aksjomatu indukcji zmuszeni jesteśmy przyjąć w teorii AR nieskończenie wiele aksjomatów podpadających pod wspólny schemat. Załóżmy, że symbol $\mathrm{A}(x)$ (należący do metajęzyka!) reprezentuje dowolną formułę zdaniową języka $\mathrm{L}_{\mathrm{AR}}$ zawierającą zmienną wolną $x$ (i ewentualnie inne zmienne wolne), natomiast $\mathrm{A}(x / v)$ - wynik podstawienia za $x$ dowolnej formuły nazwowej $v$. Możemy wówczas ustalić, że - oprócz wyszczególnionych powyżej — aksjomatami teorii AR są również wszelkie formuły zdaniowe zbudowane według schematu:

$$
\left(\mathrm{A}(x / 0) \wedge \forall_{x}(\mathrm{~A}(x) \Longrightarrow \mathrm{A}(x / \mathrm{S}(x)))\right) \Longrightarrow \forall_{x} \mathrm{~A}(x)
$$

Ponieważ formuł takich jest $\mathrm{w}$ języku $\mathrm{L}_{\mathrm{AR}}$ nieskończenie (lecz przeliczalnie) wiele, teoria AR ma nieskończenie wiele aksjomatów. Jednakże — jak tego wymagają zasady formalizacji teorii — zbiór jej aksjomatów pozostaje rozstrzygalny, ponieważ zbiór formuł podpadających pod wspólny schemat jest rozstrzygalny.

Wśród opisanych w poprzednim wykładzie interpretacji języka $\mathrm{L}_{\mathrm{AR}}$ są takie, przy których wszystkie aksjomaty teorii AR są prawdziwe, jak również takie, przy których przynajmniej niektóre z nich są fałszywe; o tych pierwszych mówimy, że są modelami teorii AR. Dobierając aksjomaty teorii staramy się, aby wśród modeli teorii znalazł się „ten, o który nam chodzi”, czyli odpowiadający z góry upatrzonej interpretacji języka teorii. W przypadku teorii AR dążymy do tego, aby jej modelem była taka interpretacja $I=\langle U, \Delta\rangle$, w której $U$ jest zbiorem liczb wszystkich naturalnych, a symbole deskryptywne denotują, odpowiednio: liczbę zero, relację mniejszości oraz operacje: następnika, dodawania i mnożenia (wszystkie określone w zbiorze liczb naturalnych). Pragnęlibyśmy również, aby teoria AR opisywała ów wyróżniony model w sposób możliwie dokładny; ideałem byłaby sytuacja, w której model ten byłby jedynym modelem teorii AR. Jednakże taki stan rzeczy nie jest osiągalny w przypadku żadnej teorii sformalizowanej, a teoria AR charakteryzuje swój zamierzony model wyjątkowo niedokładnie, czego przyczyną jest właśnie „słaba” zasada indukcji wyrażona tu za pomocą przeliczalnego zbioru aksjomatów.

Większą dokładność w charakterystyce zamierzonego modelu teorii AR można tu osiągnąć — na przykład — wzbogacając język $\mathrm{L}_{\mathrm{AR}} \mathrm{o}$ zmienne w kategorii predykatów jednoargumentowych i zezwalając na wiązanie ich kwantyfikatorami. Powinniśmy ponadto ustalić, że zmienne predykatowe przy każdej możliwej interpretacji $I=\langle U, \Delta\rangle$ reprezentują dowolne podzbiory zbioru $U$. Tak rozszerzony język $\mathrm{L}_{\mathrm{AR}}$ jest językiem syntaktycznie i semantycznie nieelementarnym. Zakładając, że $P$ jest zmienną predykatową, można w nim formułować zdania w rodzaju $\exists_{P} \forall_{x} P(x)$, co można odczytać: istnieje zbiór, do którego należy każdy przedmiot lub — utożsamiając zbiory przedmiotów $\mathrm{z}$ ich własnościami - istnieje własność, którą posiada każdy przedmiot. 
$\mathrm{W}$ tak rozszerzonym języku $\mathrm{L}_{\mathrm{AR}+}$ możemy zasadę indukcji sformułować za pomocą jednego aksjomatu:

$$
\forall_{P}\left(P(0) \wedge \forall_{x}(P(x) \Longrightarrow P(\mathrm{~S}(x))) \Longrightarrow \forall_{x} P(x)\right)^{1}
$$

Mając na względzie dowolną interpretację $I=\langle U, \Delta\rangle$, języka $\mathrm{L}_{\mathrm{AR}+}$, można powiedzieć, że aksjomat ten mówi o wszystkich podzbiorach zbioru $U$, podczas gdy ogół aksjomatów podpadających pod schemat (Ind) mówił tylko o tych podzbiorach, które dają się scharakteryzować za pomocą formuł zdaniowych języka $\mathrm{L}_{\mathrm{AR}}$. Tych ostatnich może być tylko przeliczalnie wiele, natomiast podzbiorów zbioru $U$, gdy ten jest zbiorem nieskończonym, jest — jak wiadomo - znacznie więcej.

Teoria z aksjomatem (IND) jako korzystająca z pewnych możliwości, jakie stwarza język nieelementarny, nie jest teorią elementarną. Można dowieść, że charakteryzuje ona model zamierzony teorii AR w sposób bardziej dokładny, wykluczając wszystkie tzw. modele niestandardowe ${ }^{2}$.

Ogólnie rzecz biorąc, języki nieelementarne umożliwiają formułowanie wielu aksjomatów, które nie mają równoważnych im odpowiedników w językach elementarnych, a tym samym stwarzają możliwości dokładniejszej charakterystyki zamierzonych modeli odpowiednich teorii. Tymczasem w logice i dociekaniach metamatematycznych przedmiotem badań są z reguły języki i teorie syntaktycznie elementarne. Nasuwa się zatem pytanie, co powstrzymuje logików i matematyków przed zdecydowanym preferowaniem języków i teorii nieelementarnych?

Okazuje się, że języki nieelementarne posiadają istotną wadę: dla języków tych, w przeciwieństwie do języków elementarnych, nie zachodzi twierdzenie o petności. Twierdzenie to - jak pamiętamy — mówi, że w danym języku relacja wynikania logicznego (wyznaczona przez klasę możliwych interpretacji danego języka) pokrywa się z relacją wyprowadzalności daną przez pewien rachunek logiczny. W językach nieelementarnych rachunek taki (spełniający ogólnie przyjęte wymogi efektywności) nie istnieje. Można zatem powiedzieć, że $w$ językach nieelementarnych wynikanie logiczne nie daje się $w$ petni sformalizować.

Czy jest to wada istotna? Wydaje się, że tak, bowiem wynika stąd, że w teoriach sformułowanych w językach nieelementarnych trafiają się zdania, które wynikają logicznie z aksjomatów (a więc są prawdziwe przy każdej interpretacji, przy której prawdziwe

\footnotetext{
${ }^{1}$ Przy zamierzonej interpretacji języka $\mathrm{L}_{\mathrm{AR}}$ aksjomat ten można odczytać następująco: jeśli pewna własność ma liczba 0 i wraz z każda liczba naturalna również jej następnik, to własność tę posiada każda liczba naturalna.

2 Zwykle zakłada się, że standardowym modelem arytmetyki jest taki, w którym zero jest zbiorem pustym, następnik jest operacją na zbiorach zdefiniowaną jako $X \cup\{X\}$, a zbiór liczb naturalnych jest najmniejszym zbiorem zawierającym zero i zamkniętym ze względu na operację następnika. Stosownie do tych ustaleń definiuje się dodawanie i mnożenie. Modele niestandardowe to modele, które nie są izomorficzne z modelem standardowym.
} 
są aksjomaty), natomiast nie dają się udowodnić przy użyciu reguł formalnych. Kiedy dysponujemy twierdzeniem o pełności, znajdujemy się w sytuacji — w pewnym sensie — komfortowej, bowiem (jeśli nam zdolności dopisują i szczęście sprzyja) zawsze możemy rozstrzygnąć pytanie typu:

\section{Czy zdanie A wynika z aksjomatów teorii?}

Aby wykazać, że rzeczywiście wynika, konstruujemy dowód według reguł rachunku; aby wykazać, że nie wynika - konstruujemy interpretację języka, przy której aksjomaty są prawdziwe, zaś zdanie $A$ - fałszywe. Gdy twierdzenie o pełności nie obowiązuje, może się zdarzyć, że $A$ wynika z aksjomatów, a my nie mamy sposobu, aby się o tym przekonać, ponieważ jedynym na to sposobem byłby dowód, który w tym przypadku nie istnieje.

Predylekcja do języków i teorii elementarnych sprawia, że nawet najogólniejsza lub — jak się często mówi — ,najmocniejsza” teoria matematyczna, jaką jest teoria mnogości, formalizowana jest na ogół w języku syntaktycznie elementarnym. W tym przypadku jest to język nadzwyczaj prosty, ponieważ zawiera z reguły nie więcej niż dwa symbole deskryptywne, a często tylko jeden dwuargumentowy predykat $\in$ interpretowany zwyczajowo jako bycie elementem zbioru ${ }^{3}$. W każdej sformalizowanej wersji teorii mnogości, która ma być fundamentem matematyki, zakłada się, że istnieje pewien zbiór nieskończony, lecz przeliczalny (niekiedy ze wskazaniem przykładu takiego zbioru ${ }^{4}$ ). Równocześnie zakłada się, że dla każdego zbioru $X$, istnieje zbiór wszystkich jego podzbiorów i dowodzi twierdzenia G. Cantora (1845-1918), iż zbiór wszystkich podzbiorów danego zbioru $X$ jest zawsze bardziej liczny niż sam zbiór $X$. Pozwala to dowodzić istnienia dowolnie wielu coraz to liczniejszych zbiorów nieskończonych. Tymczasem z pewnych dociekań metamatematycznych ${ }^{5}$ wynika, że każda teoria sformułowana w języku syntaktycznie elementarnym, która ma modele nieskończone, ma modele przeliczalne ${ }^{6}$. Ten pozorny paradoks wyjaśnia się następująco. Kiedy mówimy, że w teorii mnogości dowodzi się istnienia zbiorów większych niż przeliczalne, mamy na myśli zamierzoną czyli „normalną” interpretację jej języka. Jednakże niezależnie od tego jak „mocne” aksjomaty teorii mnogości przyjmiemy, dopóki formułujemy je w języku elementarnym, modele teorii będą charakteryzowane bardzo niedokładnie. W szczególności predykat $\in$ nie w każdym modelu musi być interpretowany jako należenie do zbioru.

\footnotetext{
${ }^{3}$ Kiedy $\in$ jest jedynym terminem pierwotnym teorii mnogości, musimy przyjąć, że zmienne reprezentują wyłącznie zbiory. Tym samym elementami zbiorów mogą być jedynie zbiory i w teorii nie można mówić o żadnych przedmiotach niebędących zbiorami, a w szczególności o indywiduach. Taka wersja teorii mnogości zaspokaja potrzeby matematyki, w której nie ma potrzeby zakładania istnienia jakichś przedmiotów konkretnych, natomiast nie wystarcza, gdy chcemy w niej coś powiedzieć o zastosowaniach matematyki.

${ }^{4}$ Może to być scharakteryzowany, jak w przyp. 2, zbiór liczb naturalnych.

${ }^{5}$ Będzie o nich mowa w następnym wykładzie.

$6 \mathrm{Tj}$. równoliczne ze zbiorem liczb naturalnych.
} 


\section{Wykład dziesiąty}

\section{OGRANICZENIA FORMALIZACJI}

Formalizacja języków i teorii jest produktem marzeń o zastąpieniu rozumowań rachunkiem. Pierwsze zmierzające $\mathrm{w}$ tym kierunku pomysły pojawiają się w pismach siedemnastowiecznego filozofa i matematyka G. W. Leibniza. Kreśli on projekty uniwersalnego sztucznego języka (który określa mianem characteristica universalis) oraz funkcjonującego w nim rachunku logicznego (calculus ratiocinator). Wzorcem są dlań formuły i operacje matematyczne. Leibniz zauważa, że:

[...] dowody, jakich dokonuje się w matematyce, aby zabezpieczyć się przed fałszywym rozumowaniem, nie są przeprowadzane na rzeczy samej, ale na znakach graficznych, które podstawiliśmy w miejsce rzeczy. [...] Widać stąd, że gdyby udało się wynaleźć znaki graficzne lub umowne nadające się do wyrażenia naszych myśli równie jasno i ściśle, jak arytmetyka wyraża liczby lub analiza geometryczna linie, to można byłoby w każdej dziedzinie - o ile tylko podlega rozumowaniu — zrobić wszystko, co można zrobić $\mathrm{w}$ arytmetyce i geometrii. Albowiem wszystkich dociekań zależnych od rozumowania dokonywano by przez przedstawienie znaków i rodzaj rachunku. [...] Nie trzeba by było tak sobie łamać głowy, jak jesteśmy do tego zmuszeni dzisiaj, a miałoby się mimo to pewność, że w naszej mocy leży dokonanie wszystkiego, co byłoby wykonalne ex datis ${ }^{1}$.

Zdaniem Leibniza, rachunek taki pozwoliłby uniknąć przewlekłych sporów, ponieważ:

[...] gdyby ktoś powątpiewał w to, co sam bym twierdził, rzekłbym mu: Policzmy, Panie — i tak chwytając za pióro i atrament rychło wybrnęlibyśmy z kłopotu. Dodaję jednak zawsze: o ile tylko można dokonać tego przez rozumowanie ex datis ${ }^{2}$.

Przytoczone cytaty wskazują, że Leibniz miał dość wyraźną ideę języka sformalizowanego i rachunku logicznego. Ten ostatni wyobrażał sobie zapewne jako rodzaj algorytmu pozwalającego przez odpowiednie przekształcanie wyrażeń rozstrzygnąć dowolne zagadnienie typu: Czy dany wniosek wynika logicznie z danego skończonego zbioru przesłanek?

Podobnie pojmował rachunek logiczny George Boole (1815-1864), który w traktacie An Investigation of the Laws of Thought z 1854 r. przedstawił język wzorowany na

1 Przedmowa do nauki ogólnej, [w:] G. W. L e i b n i z, Wyznanie wiary filozofa, PWN, Warszawa 1969, s. 71-72.

2 Tamże, s. 73. 
symbolice algebraicznej, w którym wyprowadzanie wniosków polega na rozwiązywaniu pewnych równań.

Nadzieje Leibniza i Boole'a, iż kwestie dotyczące wynikania logicznego można będzie rozstrzygać w sposób algorytmiczny, spełniły się w bardzo skromnym zakresie. Jest to bowiem możliwe tylko w tzw. języku monadycznym, w którym jako symbole deskryptywne występują wyłącznie predykaty jednoargumentowe. Natomiast istnieją rozstrzygalne teorie, tj. takie, w których o każdym zdaniu sformułowanym w języku danej teorii można w sposób algorytmiczny rozstrzygnąć, czy zdanie to wynika z aksjomatów teorii. Taką teorią rozstrzygalną jest, na przykład, elementarna teoria liczb naturalnych przedstawiona w poprzednim wykładzie, pod warunkiem, że usuniemy z niej znak mnożenia · i związane z nim aksjomaty 13 i 14 .

Istotnym sukcesem na drodze do formalizacji teorii było stworzenie symbolicznego języka, a ściślej ogólnego planu budowy całej klasy takich języków zwanych standardowo sformalizowanymi. Języki te są obecnie w powszechnym użyciu i noszą najczęściej nazwę języka rachunku predykatów (również rachunku kwantyfikatorów lub rachunku funkcyjnego). W języku takim można wydzielić fragment będący językiem syntaktycznie elementarnym zwany językiem węższego rachunku predykatów (lub rachunku predykatów rzędu pierwszego). Jego rozszerzeniem są języki rachunku predykatów rzędu drugiego i wyższych rzędów, w których przedmiotem kwantyfikacji są zmienne predykatowe. Sa to oczywiście języki syntaktycznie i semantycznie nieelementarne, w których semantycznemu pojęciu wynikania nie odpowiada ściśle żadne pojęcie wyprowadzalności (o ile zbiór dowodów ma być rozstrzygalny). Wynika stąd, że petna formalizacja teorii możliwa jest tylko w językach elementarnych, dla których obowiqzuje twierdzenie o petności.

Brak takiego twierdzenia dla języków rachunku predykatów wyższych rzędów jest istotną przeszkodą, skutkiem której pewne nadzieje wiązane $\mathrm{z}$ formalizacją teorii nie mogą być jednocześnie spełnione. Chodzi tu przede wszystkim o teorie, z którymi chcielibyśmy wiązać pewną określoną interpretację będącą zarazem modelem teorii. Od teorii takich skłonni jesteśmy oczekiwać, aby:

1) każde zdanie prawdziwe w zamierzonym modelu teorii miało dowód,

2) zamierzony model teorii był przez nią scharakteryzowany jednoznacznie.

Ten drugi postulat rozumiany dosłownie nie może być spełniony w przypadku żadnej teorii sformalizowanej; teorie takie mogą charakteryzować swój model zamierzony co najwyżej z dokładnościa do izomorfizmu i tym się musimy zadowolić. Zatem w najpomyślniejszym przypadku wszystkie modele danej teorii są izomorficzne. O teoriach takich mówimy, że są kategoryczne. Kategoryczność teorii można stosunkowo łatwo osiągnąć $\mathrm{w}$ przypadku teorii sformułowanych $\mathrm{w}$ języku rachunku predykatów rzędu drugiego (i wyższych rzędów). Własność tę posiada, na przykład, przedstawiona w poprzednim wykładzie teoria liczb naturalnych wzbogacona o „mocny” aksjomat indukcji IND a także nieelementarna geometria euklidesowa. Natomiast własności tej nie mają (poza szczegól- 
nymi i raczej mało interesującymi przypadkami ${ }^{3}$ ) teorie elementarne. Przesądzają o tym dwa twierdzenia. Pierwsze, zwane dolnym twierdzeniem Löwenheima-Skolema, głosi, że:

I Teoria elementarna, która ma jakiś model nieskończony, ma model przeliczalny.

Ma ono wymowę paradoksalną zwłaszcza w odniesieniu do teorii mnogości formułowanej zazwyczaj w języku elementarnym. Dowodzi się w niej istnienia zbiorów dowolnie wysokiej mocy, a tymczasem istnieje również taka jej interpretacja, przy której wszystkie zbiory, o których w niej mowa, są co najwyżej przeliczalne!

Twierdzenie drugie, zwane górnym twierdzeniem Löwenheima-Skolema, mówi, że:

Teoria elementarna, która ma model przeliczalny, ma również modele nieskończone dowolnie wysokiej mocy.

Wynika stąd, że teorie elementarne (poza wspomnianymi wyjątkami) mają modele, których zakresy są nierównoliczne, a takie modele nie mogą być izomorficzne.

Jak widać, drugi z przytoczonych tu postulatów wprawdzie może być spełniony w przypadku teorii nieelementarnych, natomiast nie czynią mu zadość teorie elementarne.

Z pierwszym postulatem rzecz ma się poniekąd odwrotnie. Jeśli każde zdanie prawdziwe w modelu zamierzonym teorii ma mieć dowód, to teoria musi być zupetna, czyli z dwóch zdań sprzecznych sformułowanych w języku teorii jedno musi mieć dowód (ponieważ przy każdej interpretacji jedno z dwóch zdań sprzecznych jest prawdziwe). Warunek ten — jak wiemy z poprzedniego wykładu — nie jest spełniony dla teorii nieelementarnych, ponieważ tutaj nie każde zdanie, które wynika logicznie z aksjomatów ma dowód; natomiast może on być spełniony dla teorii elementarnych. Istotnie, istnieją teorie elementarne zupełne, chociaż nie są to teorie o istotnym znaczeniu dla matematyki. Jednakże podstawowe teorie matematyczne, takie jak arytmetyka liczb naturalnych i teoria mnogości nie są, i co więcej — nie mogą być zupełne. Rozstrzyga o tym tzw. twierdzenie Gödla o niezupetności. Twierdzenie to wskazuje na istotne i nieusuwalne przeszkody, jakie napotyka dążenie do formalizacji teorii matematycznych, a także innych teorii, które z matematyki w istotny sposób korzystają. Wspomniane tu twierdzenie Gödla głosi, że:

Każda niesprzeczna teoria sformalizowana, w której można zinterpretować elementarną teorię liczb naturalnych AR (taką, jaką opisaliśmy w poprzednim wykładzie) jest niezupełna.

Wyjaśnienia domaga się przede wszystkim występujące tu pojęcie interpretacji względnie interpretowalności (tj. możliwości interpretacji). Nie chodzi tu o semantyczne

\footnotetext{
${ }^{3}$ Kategoryczne bywają teorie, których modele są skończone, a ich zakresy mają tę samą liczbę elementów. Aby to wyrazić w języku teorii, musimy założyć, że znak = jest we wszystkich modelach interpretowany jako identyczność.
} 
pojęcie interpretacji, którym posługiwaliśmy się dotychczas. Pojęcie interpretowalności, o którym mowa w twierdzeniu Gödla, jest syntaktyczne i dotyczy relacji między teoriami. Mówimy, że:

Teoria T jest interpretowalna $\mathrm{w}$ teorii $\mathrm{T}^{\prime}$ wtedy i tylko wtedy, gdy wszystkie symbole deskryptywne teorii T można poprawnie zdefiniować w teorii $\mathrm{T}^{\prime} \mathrm{w}$ taki sposób, że na podstawie aksjomatów teorii $\mathrm{T}^{\prime}$ oraz przyjętych definicji można udowodnić wszystkie aksjomaty teorii $\mathrm{T}$.

Należy przy tym pamiętać, że teorie, o których mowa w twierdzeniu Gödla, to teorie sformalizowane spełniające stawiane im warunki efektywności, a zatem takie, w których zbiór aksjomatów i zbiór dowodów są rozstrzygalne, a w rezultacie zbiór twierdzeń jest rekurencyjnie przeliczalny. Warto też zauważyć, że definiując symbole deskryptywne jednej teorii w drugiej, nie musimy tu starać się o zachowanie intuicyjnego sensu, który z nimi wiążemy; wymagana jest tylko formalna poprawność definicji.

Tego rodzaju niezupełność teorii, o jakiej mowa w twierdzeniu Gödla nazywa się istotnq niezupełnościq. Jak łatwo zauważyć, nie można jej usunąć przez dołączanie do teorii T dodatkowych aksjomatów (jeśli tylko zbiór aksjomatów nadal ma pozostać rozstrzygalny), ponieważ nie oddala to interpretowalności w niej teorii AR. Istotnie niezupełna jest oczywiście sama teoria AR (ponieważ każda teoria jest sama w sobie interpretowalna) oraz każda sformalizowana wersja teorii mnogości, ponieważ teoria AR z natury rzeczy musi w niej być interpretowalna, skoro teoria mnogości ma być najogólniejszą teorią matematyczną.

Z twierdzenia Gödla o niezupełności wyprowadza się często wnioski natury filozoficznej mówiące o ograniczoności możliwości poznawczych umysłu ludzkiego. Wnioski te są ryzykowne, ponieważ twierdzenie Gödla dotyczy wyłącznie efektywnych metod rozstrzygania o prawdziwości twierdzeń na podstawie aksjomatów. Nie mówi ono nic o sposobach ustalania prawdziwości aksjomatów, a — jak wiadomo — matematycy często rozszerzają istniejące teorie, wzbogacając je o nowe aksjomaty. Czym się wówczas kierują i z czego wynikają opory przed przyjmowaniem pewnych aksjomatów, jest poważnym zagadnieniem filozoficznym ${ }^{4}$, które wiąże się z innymi zagadnieniami filozoficznymi, a przede wszystkim z pytaniem o przedmiot matematyki.

\footnotetext{
4 Wiadomo, że nie wszyscy matematycy zgadzają się korzystać z aksjomatu zwanego pewnikiem wyboru. Trwają również kontrowersje związane z tym, czy przyjąć tzw. hipotezę kontinuum, czy raczej jej zaprzeczenie. Niektórzy matematycy traktują ten dylemat jako problem prawdziwości jednego z dwóch konkurencyjnych założeń.
} 


\section{Wykład jedenasty}

\section{SPÓR O PRZEDMIOT MATEMATYKI}

W kilku poprzednich wykładach staliśmy na twardym gruncie, bowiem twierdzeń, na które powoływaliśmy się, nikt nie kwestionuje. Twierdzenia te, chociaż mają pewne implikacje filozoficzne, należą do logiki względnie metamatematyki i mają podobny status jak klasyczne twierdzenia matematyczne. Teraz wkraczamy na teren zdecydowanie grząski. Rzecz ciekawa i poniekąd paradoksalna, że między matematykami, którzy rzadko spierają się o twierdzenia i definicje, nie ma zgody co do tego, o czym te twierdzenia i definicje mówią. Tolerowany jest nawet pogląd, że o niczym nie mówią.

Na pytanie, o czym mówią poszczególne teorie matematyczne, odpowiadamy zwykle bez głębszego zastanowienia, że arytmetyka mówi o liczbach, geometria o figurach, inne działy matematyki - o różnych ,abstrakcyjnych”" przestrzeniach i systemach algebraicznych. Odpowiedzi takie są zgodne z kryterium Quine'a ${ }^{2}$, że „być znaczy być wartością zmiennej związanej”, bowiem we wspomnianych teoriach rzeczywiście występują twierdzenia z kwantyfikatorami egzystencjalnymi wiążącymi zmienne reprezentujące odpowiednie przedmioty. Można oczywiście postawić pytanie, czy owe zmienne rzeczywiście jakieś przedmioty reprezentują.

Rudolf Carnap (1891-1970) proponował odróżnianie pytań ,,wewnętrznych” od ,zewnętrznych" w stosunku do teorii. Przykładem pytania wewnętrznego arytmetyki jest: Czy istnieja liczby pierwsze większe od stu? Przykładem pytania zewnętrznego - Czy liczby istnieja?? Jak wiadomo, na pierwsze odpowiadamy w ramach pewnej teorii matematycznej, natomiast drugie uchodzi za pytanie filozoficzne z zakresu ontologii. Zdaniem Carnapa, odpowiedź na takie pytania jest kwestią wyboru aparatu pojęciowego, którym zamierzamy się posługiwać. Jeśli posłużymy się aparatem pojęciowym teorii mnogości, pytanie, czy istnieją liczby, stanie się pytaniem wewnętrznym tej teorii. Do zewnętrznych zaliczył Carnap również pytanie: Czym sq liczby? W tym przypadku wybór aparatu poję-

${ }^{1}$ Słowo abstrakcyjny ujęliśmy tu w cudzysłów, ponieważ — z pewnego punktu widzenia — wszystkie obiekty matematyczne (jeśli takie istnieją) są abstrakcyjne. Kiedy mówi się o pewnych działach matematyki i ich przedmiotach jako o ,abstrakcyjnych”, to przeciwstawia się je klasycznym działom matematyki i ich przedmiotom nie jako konkretnym, lecz jako mniej abstrakcyjnym.

2 O którym była mowa w wykładzie trzecim. 
ciowego sprowadza się — zdaniem Carnapa — do wyboru języka o określonej strukturze składniowej. Na przykład wybór języka teorii typów ${ }^{3}$, w której pojęcie liczby naturalnej może być zdefiniowane, skłania do utożsamienia tych liczb z klasami klas indywiduów, natomiast sformułowanie arytmetyki w języku elementarnym ${ }^{4}$ skłania nas do uznania liczb naturalnych za indywidua.

Jednakże sam wybór języka o pewnej strukturze składniowej nie zmusza nas w sposób bezwzględny do uznania istnienia liczb lub jakichkolwiek innych przedmiotów, dopóki językowi temu nie przypiszemy określonej interpretacji, tymczasem — w myśl jednego z kilku żywotnych stanowisk w filozofii matematyki — w tzw. matematyce czystej wyrażeniom żadnej interpretacji przypisywać nie należy.

Spostrzeżenia powyższe skłaniają do wniosku, że pytanie o przedmiot matematyki, niełatwo rozstrzygnąć $\mathrm{i}$ - być może — konkluzywna odpowiedź na nie w ogóle nie jest możliwa. Skąd biorą się te trudności? Dlaczego analogicznych trudności nie napotykamy, gdy pytamy o przedmiot mineralogii lub zoologii? Odpowiedź, która się narzuca, jest następująca: obiekty matematyczne (jeśli takie istnieją) są obiektami abstrakcyjnymi. Wprawdzie inne nauki też rozprawiają o obiektach abstrakcyjnych ${ }^{5}$, ale nie wyłącznie o takich, a te, o których mowa, są z reguły w wiadomy sposób ,ufundowane” w konkretnych obiektach fizycznych. $\mathrm{Z}$ różnych powodów nie da się tego powiedzieć o liczbach i innych obiektach matematycznych.

Mający długą (bo sięgającą do Platona) tradycję podział przedmiotów na konkretne (inaczej: jednostkowe, czyli indywidua) i abstrakcyjne nie jest wolny od kontrowersji. Nie jest rzeczą bezsporną, które przedmioty są konkretne, bowiem nawet cegłę można potraktować jako pewien zbiór punktów czasoprzestrzeni, zaś zbiór jest zawsze przedmiotem abstrakcyjnym ${ }^{6}$. Natomiast wiele przedmiotów można bez wahania zaliczyć do abstrakcyjnych, ponieważ w żaden sposób nie potrafimy sprowadzić ich do konkretnych. Dotyczy to w szczególności przedmiotów, o których mowa w matematyce.

W średniowieczu istnienie i natura przedmiotów abstrakcyjnych stały się przedmiotem ożywionego sporu o uniwersalia ${ }^{7}$. Wówczas to ukształtowały się cztery stanowiska w tym sporze, znane jako: realizm (występujący w dwu odmianach, jako skrajny i umiarkowany), konceptualizm i nominalizm. O wiecznej aktualności tego sporu świadczy fakt, iż stanowiska te mają swoje odpowiedniki we współczesnej filozofii matematyki.

Odpowiednikiem średniowiecznego realizmu (głoszącego, że uniwersalia istnieją samodzielnie, niezależnie od konkretów) jest realizm teoriomnogościowy (zwany również kantoryzmem od nazwiska twórcy teorii mnogości G. Cantora). W wersji, która dziś

\footnotetext{
${ }^{3}$ Lub rachunku predykatów wyższych rzędów.

${ }^{4} \mathrm{~Np}$. w języku węższego rachunku predykatów, którym posłużyliśmy się w wykładzie dziewiątym.

5 Na przykład fizyka o polu grawitacyjnym lub elektromagnetycznym, o funkcji falowej itp.

${ }^{6}$ Chodzi tu o tzw. dystrybutywne pojecie zbioru, przy którym elementy zbioru nie mogą być pojmowane jako jego części. Różnica formalna między byciem częścią a byciem elementem polega na tym, że ten pierwszy stosunek jest przechodni, a drugi nie.

${ }^{7}$ Inaczej: powszechniki; tak właśnie określano przedmioty abstrakcyjne.
} 
ma już tylko znaczenie historyczne, jest to pogląd, iż wszystkie przedmioty, o których mowa w matematyce, są zbiorami i zajmują określone miejsce w hierarchii typów nadbudowanej nad zbiorem wszystkich indywiduów. Idea takiej hierarchii pochodzi - jak wiemy — od Russella. Wszelkie relacje i funkcje są tu, oczywiście, traktowane jako zbiory pewnego typu.

Wadą takiego ujęcia przedmiotu matematyki, dostrzeganą przez samego Russella, jest fakt, że prawdziwość twierdzeń matematycznych została tu uzależniona od liczebności zbioru indywiduów, które same nie są przedmiotami matematycznymi, lecz raczej fizycznymi (stąd kwestię ich liczebności winna rozstrzygać fizyka). Wynika stąd zależność matematyki od fizyki, bowiem niezbędne w matematyce zbiory nieskończone (zbiór liczb naturalnych i większy od niego zbiór liczb rzeczywistych) mogą pojawić się na pewnym poziomie hierarchii typów tylko wtedy, gdy nieskończony jest zbiór indywiduów, a o tym ma rozstrzygać fizyka. Russell rozwiązywał problem w ten sposób, że przyjął aksjomat nieskończoności głoszący, że zbiór indywiduów jest nieskończony, a zarazem zreformował matematykę, dopisując do każdego twierdzenia jako dodatkowe założenie (poprzednik implikacji) właśnie aksjomat nieskończoności. Dzięki temu, twierdzenia matematyczne mogłyby być prawdziwe, nawet gdyby żadne przedmioty konkretne nigdy nie istniały, ale tylko jako ,pustospełnione” (czyli z powodu fałszywego poprzednika). Konieczność postulowania istnienia nieskończonego zbioru indywiduów wynikała z podstawowej idei teorii typów Russella: dla uniknięcia antynomii należało wykluczyć tzw. zbiory mieszane (na przykład takie, do których należy zarazem pewien zbór i jego elementy).

W ujęciu Russella podstawowymi przedmiotami matematycznymi były liczby naturalne traktowane jako „moce” (czyli rodziny zbiorów równolicznych) skończonych zbiorów indywiduów, czyli przedmiotów fizycznych, które zazwyczaj liczymy. Zatem świat fizyczny nie został tu wyraźnie odgraniczony od rzeczywistości matematycznej. Radykalne odseparowanie tych dwóch światów okazało się możliwe na gruncie tzw. aksjomatycznej teorii mnogości.

Istnieje wiele wersji aksjomatycznej teorii mnogości. Do najczęściej używanych należą teoria Zermelo-Fraenkla (oznaczana skrótem ZF) oraz von Neumanna-Bernaysa-Gödla (NBG). Podstawowa różnica między nimi polega na tym, że w tej drugiej wprowadza się dodatkowo pojęcie klasy jako nadrzędne względem pojęcia zbioru (każdy zbiór jest klasą, ale nie odwrotnie). Pozwala to utrzymywać, że istnieje klasa wszystkich zbiorów ${ }^{8}$.

W aksjomatycznych teoriach mnogości nie ma potrzeby zakładać, że istnieje nieskończony zbiór indywiduów; przeciwnie, można założyć, że żadne indywidua nie istnieją i wszystko co istnieje jest zbiorem (względnie klasą). Rolę takiego założenia pełni zwykle tzw. aksjomat ufundowania, z którego wynika, że jedynym ,praelementem"9

\footnotetext{
${ }^{8}$ Założenie, że istnieje zbiór wszystkich zbiorów, chociaż wydaje się naturalne, prowadzi do sprzeczności; podobnie założenie, że istnieje klasa wszystkich klas. Dlatego w NBG zakłada się, że klasy, które nie są zbiorami (tzw. klasy właściwe) nie mogą być elementami żadnych klas.

${ }^{9}$ Czyli przedmiotem, który bywa elementem zbiorów, ale sam nie ma elementów. Jeśli, jak w oryginalnym systemie Zermeli dopuszcza się istnienie indywiduów, to one również są praelementami.
} 
i tworzywem wszystkich pozostałych zbiorów jest zbiór pusty. Gdyby tak zinterpretowana teoria mnogości miała opisywać wszystko, co istnieje, założenie to należałoby uznać za absurdalne, ale jeśli ma ona opisywać wyłącznie „świat matematyczny”, wydaje się ono racjonalne. Wszak matematyka w uzasadnieniu swoich twierdzeń nie korzysta z założeń o istnieniu kasztanów, gęsi, atomów czy innych przedmiotów fizycznych dających się policzyć.

Realizm teoriomnogościowy odwołujący się do aksjomatycznej teorii mnogości głosi, że wszelkie przedmioty, o których mówi się w matematyce są zbiorami ufundowanymi nad zbiorem pustym. Tak scharakteryzowany świat matematyczny ma również strukturę hierarchiczną, chociaż różną od hierarchii typów. Dopuszcza się tu istnienie zbiorów mieszanych, co pozwala postulować istnienie zbiorów nieskończonych, bez założenia o istnieniu indywiduów. W tym ujęciu, realizm teoriomnogościowy jest rzeczywiście — według klasyfikacji przyjętej w sporze o uniwersalia — realizmem skrajnym ${ }^{10}$.

Wspomniana tu struktura hierarchiczna to tzw. absolutna hierarchia zbiorów skonstruowana przez Johna von Neumanna (1903-1957). Dogodnym narzędziem opisu tej hierarchii są liczby porządkowe traktowane jako jednoznacznie określone zbiory. Najmniejszą liczbą porządkową jest zbiór pusty $\varnothing$. Kolejne liczby porządkowe, które wraz z liczbą $\varnothing$ określamy mianem liczb porządkowych skończonych (utożsamianych na ogół z liczbami naturalnymi) tworzymy za pomocą operacji następnika (tu symbolizowanej gwiazdką). Następnik dowolnego zbioru $X$, czyli $X^{*}$ określamy jako $X \cup\{X\}$. Uzyskujemy w ten sposób nieskończony (przeliczalny) ciąg liczb definiowanych następująco:

$$
\begin{aligned}
0 & =\varnothing, \\
1 & =\varnothing^{*}=\{\varnothing\}, \\
2 & =\varnothing^{* *}=\{\varnothing\}^{*}=\{\varnothing,\{\varnothing\}\}, \\
3 & =\varnothing^{* * *}=\{\varnothing,\{\varnothing\}\}^{*}=\{\varnothing,\{\varnothing\},\{\varnothing,\{\varnothing\}\}\}, \\
& \vdots \\
n & =(n-1)^{*}=\{\varnothing,\{\varnothing\},\{\varnothing,\{\varnothing\}\}, \ldots\}
\end{aligned}
$$

Po wszystkich liczbach porządkowych skończonych następuje pierwsza liczba pozaskończona $\omega$ będąca ich zbiorem. Jest ona, podobnie jak liczba $\varnothing$, liczba porzadkowa graniczna, ponieważ nie jest następnikiem żadnej liczby. Wychodząc od liczby $\omega$ i stosując wielokrotnie operację następnika otrzymujemy ciąg

$$
\omega, \omega^{*}, \omega^{* *}, \omega^{* * *}, \ldots
$$

dalszych liczb pozaskończonych, po których następuje kolejna liczba graniczna $\omega+\omega$, etc.

\footnotetext{
10 W porównaniu z nim rozwiązanie proponowane przez Russella mogłoby uchodzić za odmianę realizmu umiarkowanego.
} 
Korzystając z liczb porządkowych jako indeksów, można w pewien sposób usystematyzować zbiory, definiując indukcyjnie hierarchię von Neumanna:

$$
\begin{aligned}
& \mathrm{N}_{0}=\varnothing, \\
& \mathrm{N}_{a^{*}}=\mathrm{N}_{a} \cup \mathrm{P}\left(\mathrm{N}_{a}\right)^{11}, \\
& \mathrm{~N}_{\lambda}=\bigcup\left\{\mathrm{N}_{a}: a \in \lambda\right\}, \text { gdy } \lambda \text { jest liczbą graniczną. }
\end{aligned}
$$

Jak widać, liczbom porządkowym zostały tu przypisane kolejno coraz obszerniejsze zbiory:

$$
\mathrm{N}_{0}, \mathrm{~N}_{1}, \mathrm{~N}_{2}, \ldots, \mathrm{N}_{\omega}, \mathrm{N}_{\omega^{*}}, \mathrm{~N}_{\omega^{* *}}, \ldots
$$

zwane poziomami hierarchii von Neumanna. Poziom zerowy jest tu zbiorem pustym, jedynym ,praelementem” i zarazem podstawą całej hierarchii. Każdy kolejny poziom jest identyczny z poziomem bezpośrednio poprzedzającym powiększonym o wszystkie jego podzbiory; poziom odpowiadający liczbie granicznej $\omega$ (a także większym liczbom granicznym) jest sumą wszystkich poziomów niższych. Odwołując się do naszkicowanej powyżej hierarchii, można aksjomat ufundowania sformułować jak następuje: Każdy zbiór jest elementem pewnego poziomu hierarchii von Neumanna.

Jest widoczne, że na kolejnych poziomach hierarchii przybywa zbiorów. Wyjątkiem są tylko poziomy odpowiadające liczbom porządkowym granicznym, które - jak już zauważyliśmy — są tylko sumą poziomów niższych. Pierwsze zbiory nieskończone pojawiają się na poziomie $\mathrm{N}_{\omega^{*}}$; znajdujemy tu — między innymi — zbiór $\omega$ będący zbiorem liczb porządkowych skończonych (czyli liczb naturalnych). Na dalszych pozaskończonych poziomach hierarchii znajdziemy zbiory dowolnie dużej mocy, jakie tylko okażą się niezbędne w dociekaniach matematycznych. Hierarchia von Neumanna obejmuje oczywiście również wszelkie relacje i funkcje określone na dowolnych zbiorach, jeśli przyjmiemy, że one również są zbiorami. Pewne kłopoty mogą wystąpić, gdy chcemy znaleźć miejsce dla klas przestrzeni czy algebr, których zakresy mają być dowolnymi zbiorami. Rozwiązanie tej trudności może polegać na tym, że zrezygnujemy z mówienia o wszystkich zbiorach, ograniczając się do zbiorów należących do ustalonego poziomu $\mathrm{N}_{\lambda}$, gdzie $\lambda$ jest pewną dostatecznie dużą liczbą graniczną.

Realizm teoriomnogościowy jako stanowisko w kwestii przedmiotu matematyki ma niewątpliwe zalety. Pozwala utrzymywać, że matematyka ma swój przedmiot, zdecydowanie odmienny od przedmiotu nauk empirycznych, co w pewien sposób tłumaczy jej metodologiczną (a nawet epistemologiczną) odrębność. Ponadto przedmiot ten jest dobrze określony przy pomocy teorii, która sama jest teorią matematyczną.

Jednakże stanowisko realizmu teoriomnogościowego nie jest wolne od zarzutów. Jednym z nich jest rzekomo nieuprawnione utożsamianie obiektów matematycznych $\mathrm{z}$ określonymi zbiorami. Istotnie, kiedy w matematyce mówi się o zbiorach, to kwestię, czym są elementy tych zbiorów, zwykle uważa się za nieistotną; bardziej interesujące

\footnotetext{
11 Symbol $\mathrm{P}(X)$ oznacza tu zbiór wszystkich podzbiorów zbioru $X$.
} 
są działania na tych elementach, a ściślej — ich własności. Innymi słowy, matematykę interesują raczej struktury bądź formy, aniżeli ich „,podłoże”, co zdaje się wyjaśniać, dlaczego matematykę (wraz logiką) zalicza się do nauk formalnych. Utożsamianie nawet tak „,konkretnych” obiektów matematycznych jak liczby naturalne z opisanymi, jak wyżej, liczbami porządkowymi wydaje się aktem arbitralnej konwencji. Wszak równie dobrze mógłby to być ciąg: $\varnothing,\{\varnothing\},\{\{\varnothing\}\},\{\{\{\varnothing\}\}\}, \ldots$ etc., jak również wiele innych ciągów.

Na zarzut ten można odpowiedzieć następująco. Realizm teoriomnogościowy nie koliduje z poglądem, iż dla matematyki bardziej niż poszczególne zbiory interesujące są struktury „oderwane od podłoża”, natomiast pozwala takie struktury egzemplifikować, wskazując ich konkretne realizacje.

Drugi zarzut jest bardziej poważny. Odwołuje się on do faktu, iż teoria mnogości jest teorią niezupełna. Dowiedziono, na przykład, że tzw. hipoteza kontinuum jest niezależna od aksjomatów wszelkich systemów tej teorii, czyli nie wynika z nich ani ona sama, ani jej zaprzeczenie. Jeśli teoria mnogości jest opisem właściwej „rzeczywistości matematycznej” to, oczywiście, tylko jedno z tych dwóch zdań sprzecznych może być prawdziwe, lecz my nie wiemy i - być może - nie będziemy wiedzieć, które. W tej sytuacji nie mamy podstaw do twierdzenia, że istnieje jedna rzeczywistość matematyczna, a nie dwie rzeczywistości różniące się tym, że w jednej z nich prawdziwa jest hipoteza kontinuum, a w drugiej jej negacja. Ponieważ takich zdań niezależnych od teorii jest więcej, rzeczywistość, która ma być przedmiotem matematyki pozostaje w dużym stopniu nieokreślona.

Intuicjonizm to jeden z żywotnych nurtów we współczesnej filozofii matematyki. $\mathrm{W}$ kwestiach dotyczących natury poznania matematycznego przeciwstawia się on formalizmowi $^{12}$ natomiast $\mathrm{w}$ kwestiach ontologicznych — realizmowi teoriomnogościowemu. Zdaniem intuicjonistów, mocne założenia egzystencjalne teorii mnogości są nie do przyjęcia, ponieważ prowadzą do sprzeczności i paradoksów. Odpowiadając na pytanie o przedmiot matematyki, intuicjoniści nawiązują na ogół do konceptualizmu, w myśl którego wszelkie przedmioty abstrakcyjne, czyli uniwersalia, istnieją tylko w umyśle ludzkim jako pojęcia. Sam tradycyjny konceptualizm jako stanowisko w sporze o uniwersalia nastręcza pewne wątpliwości związane $\mathrm{z}$ naturą pojęć. Wprawdzie w introspekcji stwierdzamy w naszym umyśle obecność takich „bytów mentalnych” jak spostrzeżenia, wyobrażenia i uczucia, natomiast nie zauważamy tam pojęć, zwłaszcza abstrakcyjnych. Pojęcia są raczej nabytymi w trakcie nauki języka dyspozycjami do odpowiedniego użycia wyrażeń i związanych z tym zachowań. Często pojęcia utożsamia się ze znaczeniami przysługującymi wyrażeniom w określonym języku, lecz wówczas nie są one wcale czymś, co istnieje „w umyśle”.

Czym zatem są obiekty matematyczne według intuicjonistów? Na pytanie to intuicjoniści nie udzielają jasnej odpowiedzi. Utrzymują oni, że są to wytwory umysłowej aktywności matematyków, którzy obiekty te „konstruują”, ale nie zgodziliby się z opinią,

\footnotetext{
12 Stanowisko formalizmu w kwestii przedmiotu matematyki omawiamy w dalszej części.
} 
że są to pewne wyrażenia lub znaczenia tych wyrażeń, przypisywane im przez matematyków. Okazuje się, że istnienie przypisują nie tylko obiektom już „skonstruowanym”, lecz również „konstruowalnym”, które dotąd nie zostały skonstruowane ${ }^{13}$. Na pytanie, które obiekty są konstruowalne, udzielają różnych, ale w miarę jednoznacznych odpowiedzi. Są to z pewnością wszystkie liczby naturalne i przeliczalne zbiory elementów konstruowalnych, a tym samym zbiór wszystkich liczb naturalnych. Natomiast nie jest konstruowalny zbiór wszystkich podzbiorów tegoż zbioru. Nie jest jasne, w jakim sensie matematyk mógłby konstruować czyli stwarzać ${ }^{14}$ liczby i inne obiekty matematyczne, jeśli mają to być pewne przedmioty abstrakcyjne, a nie po prostu ich nazwy bądź jednoznaczne słowne charakterystyki. Wydaje się zatem, że konsekwentna interpretacja stanowiska intuicjonistów w kwestiach ontologicznych prowadzi do wniosku, że pragną oni tylko okroić świat teoriomnogościowy, a nie zaludnić go innego rodzaju przedmiotami będącymi produktem myśli.

Formalizm jest dość skomplikowanym stanowiskiem w filozofii matematyki reprezentowanym przez Dawida Hilberta (1862-1943) i ściśle związanym z jego programem badań nad matematyką. Jednakże potocznie określenie to funkcjonuje w innym znaczeniu, przy którym nie jest adekwatną charakterystyką poglądów Hilberta, chociaż jest $\mathrm{z}$ nim powszechnie kojarzone ${ }^{15}$. Tu będzie mowa o owej popularnej wersji formalizmu, do której przyznaje się wielu matematyków. Jej rodowodu należy dopatrywać się w wypowiedziach matematyka Hermana Grasmanna (1809-1877), który wprowadził pojęcie nauki formalnej pojmowanej jako niezinterpretowany system aksjomatyczny, a także rozróżnienie matematyki czystej i matematyki stosowanej, które ilustrował przykładem geometrii. Geometria jako dział matematyki czystej to zbiór formuł pozbawionych interpretacji, ten sam zbiór formuł w określony sposób zinterpretowanych jest matematyką stosowaną i zarazem działem fizyki (teorią przestrzeni fizycznej).

Matematyk hołdujący formalizmowi utrzymuje, że zadaniem matematyki jest formułowanie aksjomatów i dowodzenie, na ich podstawie twierdzeń. Formalizacja rozumowań pozwala abstrahować od sensu przesłanek i wniosków, co jest tym bardziej wskazane, że odwoływanie się do ich sensu sprzyja przemycaniu wniosków, które z aksjomatów nie wynikają, a wydają się intuicyjnie oczywiste. Poszukiwanie interpretacji, przy których aksjomaty i wynikające $\mathrm{z}$ nich twierdzenia są prawdziwe, nie jest zadaniem matematyka, lecz tego, kto pragnie z matematyki korzystać. Przez dobranie stosownej interpretacji teorie matematyczne stają się teoriami z jakiejś innej dziedziny, na przykład fizyki.

13 I zapewne nigdy nie będą, bowiem - cokolwiek by to znaczyło - trudno sobie wyobrazić, aby pewien matematyk (lub wszyscy matematycy razem wzięci) skonstruowali efektywnie wszystkie liczby naturalne.

14 Określeń „konstruować” i „stwarzać” intuicjoniści używają zamiennie.

15 Hilbert sam się do tego przyczynił pewnymi wypowiedziami, zwłaszcza na temat geometrii. Przypisuje mu się powiedzenie, że matematyka to „gra, którą rozgrywa się na papierze, posługując się pozbawionymi znaczenia symbolami”. Sugeruje to, że znaczenia wyrażeń nie odgrywają w matematyce żadnej roli. Jest to pogląd, którego Hilbert w istocie nie podzielał. 
Z przedstawionego tu poglądu wynika, że nie istnieją interpretacje teorii matematycznych, o których można by powiedzieć, że są swoiście matematyczne. Zatem zaksjomatyzowane i sformalizowane teorie matematyczne, dopóki są matematyczne, nie są teoriami w zwykłym tego słowa znaczeniu, ponieważ nie są teoriami czegoś. Gdyby zatem przedmiotem matematyki miałoby być coś, o czym mówią teorie matematyczne, to matematyka, w odróżnieniu od innych dyscyplin naukowych, nie miałaby przedmiotu. Wynika stąd, że jeśli jednak coś jest przedmiotem dociekań matematycznych, to — z punktu widzenia formalizmu - mogą nim być tylko same niezinterpretowane teorie matematyczne, a przy tym powinny to być teorie sformalizowane, ponieważ tylko takie nadają się na przedmiot ścisłych dociekań, jakie przystoją matematyce.

Tak rozumiany formalizm, głoszony, m. in., przez Haskella B. Curry’ego (1900-1982) redukuje całą matematykę do metamatematyki $\mathrm{w}$ tym znaczeniu, jakie z tym określeniem wiązał Hilbert. Pomińmy liczne wątpliwości, jakie nastręcza stanowisko formalizmu ${ }^{16}$, aby skupić się na zagadnieniu, czy zachowuje ono konsekwencję w kwestii przedmiotu matematyki. Otóż w dociekaniach metamatematycznych wyrażenia, a tym samym aksjomaty, twierdzenia i dowody nie mogą być utożsamiane z konkretnymi napisami na papierze. Muszą to być skończone, ale dowolnie długie ciągi symboli, a słowo ciąg jest tu użyte $w$ znaczeniu teoriomnogościowym jako zbiór uporządkowany lub funkcja, której dziedziną jest pewna liczba porządkowa. Uprawianie metamatematyki wymaga zatem przyjęcia pewnych dość mocnych założeń teoriomnogościowych. Nastręcza to pytanie: Czy teoria mnogości, jako podstawa dociekań metamatematycznych, jest teorią matematyczną? Jeśli nią jest, to — w myśl doktryny formalizmu — musi być teorią niezinterpretowaną i w konsekwencji również metamatematyka musi być tylko „czystą grą symboli". Natomiast jeśli w metamatematyce traktuje się teorię mnogości jako teorię zinterpretowaną, to - nie jest ona teorią matematyczną, lecz należy do jakiejś innej dyscypliny naukowej, w której uzyskała interpretację. Ale tym samym metamatematyka jako ufundowana nad teorią mnogości staje się działem wspomnianej dyscypliny naukowej i traci swoiście matematyczny przedmiot.

Wydaje się, że formaliście trudno zachować konsekwencję w kwestii przedmiotu matematyki. Może on utrzymywać — w duchu tzw. instrumentalizmu — że matematyka nie dostarcza żadnej wiedzy o rzeczywistości, lecz tylko wiedzy o narzędziach, które umożliwiają pozyskiwanie takiej wiedzy przez inne nauki. Niekonsekwencja polega na tym, że owa wiedza o narzędziach, jeśli rzeczywiście ma być wiedzą, odwołuje się do wiedzy matematycznej, której istnieniu formalista zaprzecza.

\footnotetext{
16 Na przykład, co może skłaniać matematyków do tworzenia raczej tych, a nie innych systemów aksjomatycznych, jeśli nie jest to ich przedmiot? Czy może to być wyłącznie ich użyteczność dla innych nauk?
} 


\section{Wykład dwunasty}

\section{SPÓR O NATURĘ POZNANIA MATEMATYCZNEGO}

Matematykę można postrzegać jako rodzaj wiedzy, jak również jako rodzaj narzędzia, przy czym jedno nie wyklucza drugiego. Z punktu widzenia formalisty, teoria matematyczna może być tylko narzędziem i to pod warunkiem, że znajdzie zastosowanie w jakiejś nauce „realnej”, gdzie zostanie odpowiednio zinterpretowana. Formalista może również utrzymywać, że przypisywanie jej określonej interpretacji nie jest tu niezbędne, gdyż może ona być użyta po prostu jako pewien rachunek pozwalający wyprowadzać zdania o określonej treści z innych zdań. Jest to punkt widzenia instrumentalisty, który podobny charakter skłonny jest przypisywać również pewnym wysoce teoretycznym partiom nauk empirycznych.

$\mathrm{Z}$ punktu widzenia realisty teoriomnogościowego matematyka jest wiedzą, a jej przydatność jako narzędzia użytecznego dla innych nauk polega na tym, że dostarcza modeli matematycznych pewnych zjawisk empirycznych. Modele są tu rozumiane nie jako wyrażenia językowe (np. układy równań), lecz jako obiekty matematyczne odwzorowujące strukturę zjawisk fizycznych.

Przez szereg stuleci powszechne było przekonanie, że matematyka jest wiedzą, i to wiedzą o szczególnych walorach. Owe walory to konieczna prawdziwość i towarzysząca jej apodyktyczna pewność. Określenia te pochodzą od Immanuela Kanta (1724-1804), ale walory te przypisywano matematyce już wcześniej. Ponieważ walorów tych zdecydowanie odmawiano wiedzy empirycznej, należało utrzymywać, że wiedza matematyczna jest aprioryczna, czyli nie wymaga żadnego potwierdzenia w doświadczeniu zmysłowym. Pogląd ten również dziś ma licznych zwolenników.

Przymiotnik aprioryczna jest określeniem negatywnym i nie wyjaśnia, jakie są źródła i podstawy wiedzy matematycznej. Filozofia proponowała tu wiele rozwiązań. Platon (427-347 p.n.e.), zdaniem którego matematyka traktuje o przedmiotach idealnych, głosił, że wiedzę matematyczną nabywa dusza ludzka przed połączeniem się z ciałem, za sprawą niezmysłowego oglądu wspomnianych przedmiotów. Zdaniem św. Augustyna, prawdy matematyczne odkrywamy, uzyskując dostęp do umysłu boskiego poprzez iluminację. Gottfried Leibniz (1649-1716) twierdził, że twierdzenia matematyczne mogą być udowodnione na podstawie logicznych zasad tożsamości i sprzeczności, które są z założenia prawdami rozumowymi. 
Wielu matematykom, którzy na przełomie XIX i XX wieku zajęli się problemem podstaw matematyki, bliskie okazało się stanowisko Kanta. Wyróżnił on sqady analityczne mające charakter aprioryczny i odpowiadające $w$ zasadzie prawdom rozumowym Leibniza, zaś wśród pozostałych, zwanych syntetycznymi (które Leibniz i inni uważali za empiryczne prawdy o faktach) wyróżnił sądy syntetyczne a priori. Podstawowe twierdzenia geometrii i arytmetyki to — zdaniem Kanta - właśnie sądy syntetyczne a priori. Sądy takie nie znajdują gwarancji swej prawdziwości ani w logice, ani w strukturze pojęć; ich podstawą jest — według Kanta — rodzaj intuicji, którą nazywa czystą naocznościa, wyprzedzającej i umożliwiającej doświadczenie zmysłowe.

Geometria kładzie u swych podstaw czystą naoczność przestrzeni. Arytmetyka nawet swoje pojęcia liczb wytwarza przez kolejne dołączanie jednostek w czasie [...] Oba zaś te przedstawienia są tylko danymi naocznymi; jeżeli bowiem z empirycznych danych naocznych ciał i ich zmian (ruchu) usuniemy wszelki pierwiastek empiryczny [...], to pozostanie jeszcze przestrzeń i czas. Są one przeto czystymi danymi naocznymi, które stanowią a priori podstawę oglądów empirycznych i dlatego same nigdy nie mogą być usunięte ${ }^{1}$.

Po Kancie wielu matematyków przypisywało przynajmniej niektórym twierdzeniom matematycznym charakter sądów syntetycznych a priori, na ogół nie podzielając poglądów epistemologicznych Kanta w całości; po prostu zakładali istnienie pewnego rodzaju nieomylnej intuicji pozwalającej rozpoznać prawdy matematyczne nieredukowalne do logiki.

Geometria, którą miał na myśli Kant, to oczywiście geometria euklidesowa, podówczas jedyna teoria matematyczna mająca postać systemu aksjomatycznego. Uchodząc tradycyjnie za teorię matematyczną, była ona zarazem interpretowana jako teoria przestrzeni fizycznej, przedstawiająca adekwatnie stosunki przestrzenne między fizycznymi przedmiotami. Dopiero odkrycie, a raczej skonstruowanie w XIX wieku geometrii nieeuklidesowych zmieniło poglądy na geometrię i wprowadziło do niej rozróżnienie na „czystą” i „stosowaną”. Ta druga utraciła status teorii matematycznej, zaś pierwsza przestała być powszechnie uznawanym wzorcem wiedzy ,,apodyktycznie pewnej”. Jej miejsce zajęła arytmetyka, którą zaksjomatyzował Giuseppe Peano (1858-1932), a później — jako teoria bardziej podstawowa — teoria mnogości. Spór o źródła i podstawy pewności w matematyce dotyczył odtąd przede wszystkim arytmetyki liczb naturalnych, zwłaszcza od chwili, gdy Julius Dedekind (1831-1916) zredukował do niej teorię liczb rzeczywistych.

Ideę Leibniza redukcji arytmetyki do logiki podjęli Gottlob Frege (1848-1925) i następnie Bertrand Russell (1872-1970). Chodziło tu o logikę w interpretacji przedmiotowej, a więc nie o „prawa myślenia”, lecz o najogólniejsze prawdy dotyczące wszystkiego, co istnieje. „Konieczna prawdziwość” tak rozumianych twierdzeń logiki nie budziła żadnych wątpliwości, toteż redukcja arytmetyki do logiki za pomocą łańcucha definicji

${ }^{1}$ I. K a n t, Prolegomena do wszelkiej przyszłej metafizyki, która będzie mogła wystapić jako nauka, PWN, Warszawa 1993, s. 47. 
pojęć arytmetycznych wydawała się najlepszym sposobem wyjaśnienia ,apodyktycznej pewności" twierdzeń matematycznych. Redukcja taka oznaczałaby, że wszelkie twierdzenia matematyczne są - wbrew opinii Kanta — sądami analitycznymi, o prawdziwości zagwarantowanej przez prawa logiki i wspomniane definicje.

Jednakże program takiej redukcji, znany jako program logicyzmu, nie mógł być w pełni zrealizowany. Wszystkie prawa logiki, w uświęconym przez tradycję znaczeniu, są tautologiami, natomiast postulowana przez logicystów redukcja wymagała korzystania również z założeń nietautologicznych ${ }^{2}$. Brak sukcesów w realizacji programu logicyzmu skłaniał do przekonania, że nie wszystkie twierdzenia matematyki są sądami analitycznymi. Na przykład Henri Poincaré (1854-1912) stanowczo bronił poglądu, że niezbędna w matematyce zasada indukcji jest sądem syntetycznym a priori i do logiki zredukować się nie daje.

Poincaré był jednym z twórców stanowiska filozoficznego zwanego konwencjonalizmem, które odnosił do geometrii i fizyki, lecz nie do arytmetyki. Wypowiedzi Poincarégo na temat geometrii nie są konsekwentne. Utrzymuje on, że wybór jednego z wielu systemów geometrii na użytek fizyki jest arbitralny, czyli nie jest zdeterminowany przez doświadczenie. Wybieramy taki system, co do którego mamy nadzieję, że okaże się „,najwygodniejszy”, czyli — w szczególności — sprawi, że struktura opartej na geometrii teorii fizycznej będzie najprostsza z możliwych. O aksjomatach geometrii mówi Poincaré, że są „konwencjami” i z tej racji nie są ani prawdziwe, ani fałszywe. Stwierdzenie to jest mylące; $w$ istocie konwencją nie jest sam aksjomat, lecz umowa, aby aksjomatom przypisywać tylko taką interpretację, przy której okażą się one prawdziwe. Takie właśnie konwencjonalistyczne podejście do aksjomatów geometrii, ale nie „stosowanej”, lecz „czystej”, deklarował Hilbert. Aksjomaty ,prawdziwe na mocy umowy” są przez wielu uważane za zdania analityczne $e^{3}$ i tym samym prawdziwe a priori, stąd konwencjonalizm wydaje się jednym z możliwych sposobów obrony i wyjaśnienia ,,apodyktycznej pewności" twierdzeń matematycznych.

Jednakże ta linia obrony budzi poważne zastrzeżenia. Czy rzeczywiście wystarczy „umówić się" co do sposobu interpretacji aksjomatów, aby zagwarantować ich prawdziwość? Wszak nasza umowa nie może być zrealizowana, jeśli taka interpretacja, przy której aksjomaty są prawdziwe, po prostu nie istnieje. Jak wykazały późniejsze badania metamatematyczne nad modelami teorii, kiedy żaden pozalogiczny termin pierwotny teorii nie ma interpretacji ustalonej lub choćby tylko ograniczonej ,z zewnątrz”, wystarczającym warunkiem istnienia interpretacji, przy której aksjomaty są prawdziwe jest ich niesprzeczność $c^{4}$. Kwestią kluczową staje się wówczas pytanie: Jak można przekonać

\footnotetext{
2 Jednym z nich było przyjęte przez Russella założenie o istnieniu nieskończenie wielu indywiduów, o którym wspomniano w wykładzie trzecim.

${ }^{3}$ Pojęcie analityczności zostało tu nieco rozszerzone w porównaniu z tym, którym posługiwał się Kant, a po nim Frege; ponadto zamiast o sądach mówi się tu o zdaniach analitycznych.

4 Jeżeli sprzeczność określa się w sposób formalny, jako wyprowadzalność zdań sprzecznych według reguł rachunku logicznego, to spostrzeżenie to odnosi się wyłącznie do teorii elementarnych.
} 
się o niesprzeczności układu aksjomatów? Ponieważ w przypadku poważnych teorii matematycznych możliwe są tylko tzw. względne dowody niesprzeczności, oparte na aksjomatach „mocniejszych” niż te, których niesprzeczności się dowodzi, dowody takie nie są przekonywające. W tej sytuacji jedynym argumentem na rzecz niesprzeczności danego układu aksjomatów staje się „doświadczenie” matematyków, którzy dowodząc twierdzeń na podstawie danego układu aksjomatów, na sprzeczność się nie natknęli. Argument taki nie jest oczywiście żadnym dowodem, ponieważ dalsze dociekania, które nigdy się nie kończą, mogą jakąś sprzeczność ujawnić. Nasuwa się ponadto pytanie, czy wspomniane tu ,doświadczenie” matematyków nie odwołuje się w sposób nieunikniony do doznań zmysłowych (na przykład do wzrokowego postrzegania przekształcanych napisów). Gdyby tak było, to przeświadczenie o apriorycznym, a więc niezależnym od doświadczenia, charakterze poznania matematycznego okazałoby się mitem, chociaż zależność od doświadczenia miałaby tu nieco inny charakter niż w tzw. naukach empirycznych.

Teza o aksjomatach prawdziwych na mocy konwencji budzi też inne zastrzeżenia. Jeśli aksjomaty teorii są niesprzeczne, to interpretacji, przy których są one prawdziwe jest wiele, a zdarzają się wśród nich również interpretacje nieizomorficzne, a więc radykalnie różne od innych. Tymczasem matematycy na ogół mają na względzie tylko tzw. interpretacje standardowe, a niekiedy mają nawet poczucie, że z daną teorią związana jest tylko jedna, ściśle określona interpretacja. Na przykład, arytmetyka — ich zdaniem - mówi o liczbach i tylko o nich, czymkolwiek by one były, zaś teoria mnogości o jednym, tym „realnym”, świecie teoriomnogościowym. Z kolei, jeśli przyjmiemy, że wśród interpretacji, przy których prawdziwe są aksjomaty teorii, żadnej nie wyróżniamy, bo nie mamy na to sposobu, to traci sens naturalne pytanie, czy prawdziwe (względnie fałszywe) jest jakieś zdanie niezależne od tych aksjomatów ${ }^{5}$. Jest tak dlatego, że zdanie takie jest prawdziwe tylko przy niektórych spośród interpretacji, przy których prawdziwe są aksjomaty.

Wyszczególnione tu racje skłaniają wielu matematyków do odrzucenia konwencjonalistycznego podejścia do aksjomatów. Utrzymują oni, że w przypadku pewnych teorii matematycznych, takich jak arytmetyka i teoria mnogości, możliwa jest jednoznaczna interpretacja aksjomatów dzięki jakiejś niezmysłowej percepcji przedmiotów tych teorii. Ta niezmysłowa percepcja, rodzaj szczególnej intuicji matematycznej, pozwala ponadto rozstrzygać o prawdziwości aksjomatów, jak również zdań od nich niezależnych, co umożliwia postępujące rozszerzanie układu aksjomatów i redukowanie liczby zdań formalnie nierozstrzygalnych.

W przeszłości, spośród znanych filozofów tylko John Stuart Mill (1806-1873) zaprzeczał koniecznej prawdziwości i pewności twierdzeń matematycznych. Mając na uwadze

\footnotetext{
5 W pytaniu tym występuje tzw. absolutne pojęcie prawdziwości, które ma sens, gdy wyrażeniom danego języka przypisano jedną, ściśle określoną interpretację. Kiedy takiej interpretacji nie umiemy wskazać, możemy posługiwać się tylko względnym pojęciem prawdziwości, zrelatywizowanym do dowolnej interpretacji.
} 
głównie pojęcia geometrii, utrzymywał, że nie ma przedmiotów, które odpowiadałyby ściśle definicjom tych pojęć. Pojęcia te są produktem myślowego abstrahowania od pewnych własności przy jednoczesnej idealizacji (czyli minimalizowaniu lub maksymalizowaniu) innych. Nie jest również prawdą, by twierdzenia geometryczne odnosiły się do jakichś przedmiotów idealnych, bowiem przedmioty takie nie istnieją. Twierdzenia geometryczne odnoszą się zatem do przedmiotów realnych, ale są tylko w przyblizeniu prawdziwe. Są one wynikiem uogólnień i tym samym mają charakter hipotez, podobnie jak twierdzenia fizyki czy chemii.

Warto zauważyć, że współcześnie mało kto kwestionuje empiryczny rodowód pojęć i twierdzeń matematycznych. Jean Piaget (1896-1980), twórca dyscypliny, którą nazwał epistemologia genetyczna, prowadził szczegółowe badania nad przyswajaniem sobie pojęć matematycznych przez dzieci. Wskazują one, że w procesie tym istotną rolę pełni manipulowanie przedmiotami. Wraz z przyswajaniem sobie pewnych pojęć następuje uprzytomnienie sobie pewnych prawd matematycznych. Na przykład przyswajając sobie pojęcie równoliczności, dzieci zauważają, że usuwając z dwu zbiorów równolicznych po jednym elemencie, otrzymuje się zbiory nadal równoliczne. Jest to spontaniczne uogólnienie, lecz można je interpretować jako etap w procesie kształtowania się intuicji matematycznej. W kolejnych fazach tego procesu, już jako dorośli, wykraczamy poza zbiory przedmiotów, którymi można praktycznie manipulować, co wszakże nie sprowadza się do prostego uogólnienia przećwiczonych przypadków. Nowe przedmioty, na przykład zbiór pusty i zbiory zbiorów, należy postulować, czyli przyjąć odpowiednie założenie ontologiczne, że przedmioty takie istnieją ${ }^{6}$. Nasza decyzja, aby pewne wcześniejsze uogólnienia empiryczne przenieść na przedmioty postulowane, nie jest uogólnieniem empirycznym. Kiedy wśród przedmiotów postulowanych pojawiają się zbiory nieskończone, musimy podejmować decyzje, które z empirycznych doświadczeń (a te zawsze ograniczają się do elementów zbiorów skończonych) przenieść na zbiory nieskończone, unikając sprzeczności i paradoksów ${ }^{7}$.

Rzeczywistość, o której mówią różne dyscypliny naukowe, pełna jest przedmiotów postulowanych, a odróżnienie ich od pozostałych nastręcza pewne trudności. Zazwyczaj

6 Sam Piaget inaczej przestawia ten etap kształtowania się intuicji matematycznej, utrzymując, że „...czynności logiczno-matematyczne dziecka mogą w pewnym momencie oderwać się od zastosowań do przedmiotów fizycznych i zinterioryzować się jako operacje, które mogą być wykonywane symbolicznie”. Jednakże dalsze konkluzje Piageta wydają się zbieżne z tu przedstawionymi: „Inaczej mówiąc, to właśnie od pewnego poziomu rozwojowego istnieje czysta logika i matematyka, którym doświadczenie staje się niepotrzebne. [...] czysta logika i czysta matematyka mogą nieskończenie daleko wykraczać poza doświadczenie: nie są one ograniczone fizycznymi właściwościami przedmiotu”. J. P i a g e t, Psychologia i epistemologia, PWN, Warszawa 1977, s. 81.

7 Jak wiadomo, fakt, iż pewne twierdzenia słuszne dla zbiorów skończonych nie zachodzą dla zbiorów nieskończonych, długo powstrzymywały matematyków przed zaakceptowaniem „,nieskończoności aktualnej”. Również tzw. pewnik wyboru, który znakomicie się sprawdza praktycznie na skończonych rodzinach zbiorów skończonych, rodzi pewne konsekwencje uchodzące za paradoksalne, gdy rodzina zbiorów, z których mamy dokonać wyboru nie jest skończona. 
nie zaliczamy do postulowanych przedmiotów fizycznych względnie trwałych, dobrze wyodrębnionych z otoczenia i dostępnych percepcji zmysłowej. Niektóre z nich, jak kasztany bądź szklanki, mogą być przedmiotem manipulacji prowadzących do prostych uogólnień kształtujących intuicję matematyczną. We wszystkich tych uogólnieniach empiryczne różnice między przedmiotami nie odgrywają roli istotnej; liczy się tylko to, co zwykle określamy mianem formalnych własności zbiorów i relacji. W tej sytuacji zależność wspomnianych uogólnień od konkretnych faktów empirycznych wydaje się niemożliwa, a podawane niekiedy przykłady sumowania rozłącznych zbiorów bakterii bądź owiec, które przeczą rzekomo zasadom dodawania liczb kardynalnych ${ }^{8}$, są po prostu źle dobrane. Tę niezależność uogólnień od faktów empirycznych można wzmocnić, postulując istnienie zbiorów, które nie są zbiorami konkretnych przedmiotów.

Z kolei zakres twierdzeń dotyczących przedmiotów postulowanych można odpowiednio zawęzić ograniczając go do przedmiotów oderwanych od empirycznego podłoża. Coś takiego ma miejsce w tej wersji realizmu teoriomnogościowego, w której rzeczywistość matematyczną redukuje się do konstrukcji ufundowanych nad zbiorem pustym. Ten — pod pewnym względem skrajny — przykład pokazuje, że empiryczny rodowód pojęć i twierdzeń matematycznych nie musi pociągać za sobą ich poznawczej zależności od doświadczenia.

Realizm teoriomnogościowy to stanowisko w kwestii przedmiotu matematyki. Wynika z niego, że wiedza matematyczna jest zabezpieczona przed obaleniem przez doświadczenie $^{9}$, ale nie wynika, że jest ona wiedzą apodyktycznie pewną. Wiedza ta opiera się na założeniach egzystencjalnych dotyczących przedmiotów postulowanych. Założenia te można bez końca wzmacniać, postulując istnienie coraz większych liczb porządkowych i dobudowując coraz to nowe piętra hierarchii von Neumanna. Możemy również przyjąć założenia alternatywne w stosunku do uznanych; na przykład postulować istnienie zbiorów nieufundowanych (tj. zbiorów, w których każdy element ma własne elementy itd. w nieskończoność). Nawet gdyby było wiadomo, że przyjęte przez nas założenia są niesprzeczne, skąd mamy czerpać pewność, iż postulowane przez nas zbiory istnieją i mają te własności, które im przypisujemy?

Założenia te, ponieważ nie są wymuszone przez doświadczenie, wydają się arbitralne i nie widać powodu, dla którego rzeczywistość miałaby je spełniać. Toteż wielu filozofów uważa, że nie mamy tu do czynienia z prawdziwą rzeczywistością, że pojęcie istnienia zostało tu nadmiernie rozszerzone. Stwierdzić, że istnieją i poznawać możemy tylko takie przedmioty, które oddziałują przyczynowo na nasz mózg, a jak dotąd nie znamy innej drogi oddziaływania nań jak tylko poprzez organy zmysłów. W połączeniu z przeświadczeniem, że w ten sposób mogą oddziaływać tylko konkretne przedmioty fizyczne, prowadzi to na ogół do wniosku, że przedmiot matematyki nie istnieje, a matematyka nie jest wiedzą pewną, ponieważ w ogóle nie jest wiedzą.

\footnotetext{
${ }^{8}$ Ponieważ bakterie $\mathrm{w}$ trakcie operacji fizycznego łączenia zbiorów się dzielą, a w łączonych stadach owiec rodzą się nowe jagnięta.

${ }^{9}$ Wszak wydaje się niewiarygodne, aby doświadczenie zmysłowe miało coś do powiedzenia na temat zbiorów skonstruowanych ze zbioru pustego jako „ostatecznego” elementu.
} 
Bardziej przychylne dla matematyki wydaje się rozwiązanie następujące. Przedmioty, o których mówią teorie matematyczne, nie istnieją realnie, ale - jeśli teorie te są niesprzeczne - to są one przedmiotami możliwymi. Chodzi tu nie o fizyczną możliwość, lecz o możliwość logiczna. Zatem o tym, co jest możliwe, a co nie, decyduje logika, i wszystko co mówimy w sposób niesprzeczny o jakichś przedmiotach jako o możliwych, nie twierdząc, że istnieją, jest niewątpliwie prawdziwe. Wynika stąd, że matematyka może dostarczyć wiedzy apodyktycznie pewnej, pod warunkiem, że dotyczy ona przedmiotów możliwych. Przedmioty te mogą tworzyć struktury, które mniej lub bardziej adekwatnie naśladują struktury utworzone z przedmiotów realnych.

Rozwiązanie to spotyka się z następującą krytyką. Wprawdzie trudno nam ustrzec się od mówienia o sytuacjach możliwych, które się nie zrealizowały, lecz wprowadzanie do rozważań możliwych przedmiotów jest przemycaniem założenia, że one jakoś istnieją, mianowicie istnieja potencjalnie. Tym samym wprowadza się dwa „sposoby istnienia”: istnienie realne oraz istnienie potencjalne. Jednakże zdaniem krytyków, pojęcie istnienia jest jedno i wyraża się za pomocą kwantyfikatora egzystencjalnego, a posługiwanie się pojęciem istnienia potencjalnego jest wybiegiem polegającym na postulowaniu przedmiotów, o których naprawdę sądzi się, że nie istnieją. Ponadto, gdybyśmy przyjęli, że przedmioty możliwe stanowią gatunek przedmiotów istniejących różnych od realnych, stanęlibyśmy przed ogromem zagadnień, których sens jest wątpliwy, ponieważ nie mamy żadnego pomysłu na sposób ich rozstrzygania ${ }^{10}$.

10 Zwrócił na to uwagę W. V. Quine, pisząc: „Czy więcej jest możliwych ludzi chudych, czy tłustych? Ilu z nich jest do siebie podobnych? Czy może podobieństwo między nimi wystarcza, by byli oni jednym człowiekiem? Czy żadne dwie rzeczy możliwe nie są do siebie podobne? Czy znaczy to to samo, co stwierdzenie, że jest niemożliwe, aby dwie rzeczy były do siebie podobne? Czy też może pojęcie identyczności jest po prostu niestosowalne do możliwości nieurzeczywistnionych? Czy jednak mówienie o bytach, o których nie można sensownie twierdzić, że są identyczne same z sobą i różne od innych bytów, ma w ogóle sens?" W. V. Q u i n e, Z punktu widzenia logiki, PWN, Warszawa 1969 , s. 13. 



\section{Wykład trzynasty}

\section{NAUKI ŚCISEE, CZYLI MATEMATYKA STOSOWANA}

Do nauk ścisłych zalicza się zazwyczaj matematykę, fizykę, astronomię, chemię i - ewentualnie - jakieś ich odgałęzienia. Jest oczywiste, że nauki te tworzą pewną naturalną całość z uwagi na zachodzące między nimi więzy kooperacyjne. Wiadomo, że fizyka i astronomia nie mogłyby zaistnieć i rozwijać się bez matematyki, z kolei chemia — bez matematyki i fizyki. Natomiast z teoriopoznawczego i metodologicznego punktu widzenia tak wyodrębnione nauki ścisłe nie tworzą grupy jednorodnej; matematyka zdecydowanie odbiega od pozostałych. Te pozostałe są bez wątpienia naukami empirycznymi, czego o matematyce powiedzieć nie można. Nawet, jeśli praktykę dedukcyjną matematyków, która odwołuje się do postrzegania i przekształcania wyrażeń, nazwiemy doświadczeniem zmysłowym, czyli empiria, to jest to inny rodzaj doświadczenia niż to, z którym mamy do czynienia w eksperymentach fizycznych i obserwacjach astronomicznych. Zatem, jeśli chcemy powiedzieć o naukach ścisłych coś istotnego z filozoficznego punktu widzenia, musimy matematykę wyłączyć z rozważań ${ }^{1}$.

Na czym polega swoistość tak okrojonych nauk ścisłych i czy nobilitujący przymiotnik ścisłe pełni tu funkcję różnicującą? Czy pozostałe nauki empiryczne są nieścisłe bądź mniej ścisłe? Wydaje się, że do określenia ścisłe nie należy tu przywiązywać zbyt wielkiej wagi; ma ono zróżnicowany zakres zastosowań i przy różnych zastosowaniach oznacza na ogół coś innego, zaś nauki ścisłe nie są ścisłe pod każdym względem. Jak już zauważyliśmy w wykładzie czwartym, pod względem ścisłości w formułowaniu twierdzeń fizyka nie dorównuje matematyce ${ }^{2}$, a nawet pewnym naukom empirycznym niezaliczanym do

\footnotetext{
1 Dla nauk ścisłych (po odrzuceniu matematyki) adekwatne wydaje się określenie „,matematyczne przyrodoznawstwo”, którym posługiwał się Kant w odniesieniu do fizyki Newtona; jednakże dziś brzmi ono zbyt archaicznie.

2 Dotyczy to również definiowania pojęć, co potwierdza w swoich wykładach R. P. Feynman. Po postawieniu pytania, „Co to jest siła?”, zauważa: „Czytelnik może tu zaprotestować: «Nie podoba mi się ten brak precyzji, chciałbym mieć wszystko ściśle zdefiniowane; zresztą w niektórych książkach mówi się, że nauki ścisłe są naprawdę ścisłe i wszystko jest w nich dobrze określone». Jeśli upieracie się, by dać wam ścisłą definicję siły, pragniecie rzeczy niemożliwej, której nigdy nie otrzymacie!” R. P. F e y n m a n, R. B. Le ig h to n, M. S a n d s, Feynmana wykłady z fizyki, t. I. PWN, Warszawa 1974, s. 184. Brak
} 
nauk ścisłych. Gdy mowa o rozumowaniach, to wzorem ścisłości są wnioskowania dedukcyjne, a w fizyce nie wszystkie wnioskowania mają charakter dedukcji. Kiedy mamy na względzie postać teorii, to ideałem ścisłości byłyby teorie sformalizowane, ale ten wzorzec nie znajduje zastosowania w naukach ścisłych. Wbrew postulatom koryfeuszy fizyki Galileusza i Newtona, w naukach ścisłych nie znalazła szerszego zastosowania również metoda aksjomatyczna.

A jednak właśnie fizykę należy uznać za paradygmat nauki ścisłej. Rozważmy zatem kwestię na czym polega swoistość fizyki jako dyscypliny naukowej. Fizycy zazwyczaj podkreślają, że w odróżnieniu od innych nauk zajmujących się jakościowymi aspektami rzeczywistości przyrodniczej, fizyka traktuje wyłącznie o wielkościach. Lecz cóż to są wielkości? Zwykle mówi się, że wielkości, czyli charakterystyki ilościowe przedmiotów to — w przeciwieństwie do jakości (czyli ich cech jakościowych) — coś, co można zmierzyć. Wyjaśnienie to nastręcza kolejne pytanie: Na czym polega pomiar?

Ogólnie, chociaż niezbyt ściśle, charakteryzuje się pomiar jako takie przyporządkowanie liczb ${ }^{3}$ przedmiotom, które na podstawie związków między liczbami pozwala wnioskować o zachodzeniu pewnych zależności między przedmiotami. Każdy pomiar jest oczywiście pomiarem pewnej wielkości, a ściślej pomiarem przedmiotów pod względem pewnej wielkości. Wielkością jest zatem właśnie ten wzgląd czy aspekt, pod którym dany przedmiot mierzymy. Aspektów tych jest zwykle wiele; na przykład wielkościami fizycznymi charakteryzującymi konkretny pręt miedziany są długość, masa, gęstość, przewodnictwo elektryczne i cieplne, sprężystość itp. Czym są wyszczególnione tu wielkości?

Rozważmy to na przykładzie prostej wielkości geometrycznej, jaką jest długość przypisywana odcinkom. Przyporządkowując odcinkom liczby rzeczywiste ze względu na ich długość, powinniśmy przypisać tę samą liczbę wszystkim odcinkom wzajemnie przystającym. Ponadto, ilekroć odcinek $a$ zawiera się w odcinku $b$, należy odcinkowi $a$ przypisać liczbę nie większą niż odcinkowi $b$. I jeszcze jedno: gdy odcinek $c$ powstaje przez połączenie odcinków $a$ i $b$, to liczba przypisana $c$ musi być sumą liczb przypisanych $a$ i $b$. Każda funkcja, która przyporządkowuje odcinkom liczby i spełnia powyższe warunki, jest skala wielkości, zwanej długościq. Skal, które warunki te spełniają jest całe kontinuum, bowiem wybór skali zależy od tego, którym odcinkom przyporządkujemy liczbę 1 . Wynika stąd, że wielkości nie można utożsamiać z jej skalą. Długościa danego odcinka nie jest żadna liczba ani funkcja o wartościach liczbowych; jest nią własność wspólna wszystkim odcinkom do niego przystającym, względnie $\mathrm{klasa}^{4}$

ścisłej definicji pojęcia siły można by próbować wyjaśnić stwierdzeniem, że jest to pojęcie pierwotne i definicji nie wymaga. Kłopot polega na tym, że w wykładzie mechaniki i innych teorii fizycznych trudno przeprowadzić podział pojęć na pierwotne i wtórne.

${ }^{3}$ Nie zawsze są to liczby. W fizyce są to często pewne złożone konstrukty liczbowe, takie jak wektory, tensory itp.

${ }^{4}$ Potoczne pojęcie własności jest pod pewnym względem niejasne, mianowicie nie mamy wyraźnego kryterium pozwalającego w każdym przypadku rozstrzygać, czy mamy do czynienia z tą samą własnością, czy z dwoma różnymi własnościami. Z tego powodu lepiej jest mówić o klasach (zbiorach), dla których kryterium takie istnieje. 
takich odcinków, zaś długość jako taka — to rodzina wszystkich takich klas. Długość jest wielkością, ponieważ relacja przystawania odcinków, która taką rodzinę klas pozwala skonstruować, jest równoważnościa, czyli relacją zwrotną, symetryczną i przechodnią. To owa równoważność wyznacza aspekt pod którym przedmioty mierzymy, zaś wielkość można ogólnie zdefiniować jako rodzinę klas abstrakcji generowana przez danq relację równoważności.

Kiedy zakłada się, że każdej relacji będącej równoważnością odpowiada pewna wielkość, to różnica między wielkościami jako cechami ilościowymi a cechami jakościowymi ulega zatarciu ${ }^{5}$. Aby ją odtworzyć, należy wyróżnić pewien rodzaj wielkości, na przykład wielkości ekstensywne ${ }^{6}$. Nie jest więc osobliwością fizyki i innych nauk ścisłych wypowiadanie się wyłącznie o wielkościach, natomiast jest nią stosowanie pomiaru $w$ taki sposób, który umożliwia korzystanie z różnych zaawansowanych dziatów matematyki.

$\mathrm{Na}$ czym polega korzystanie z matematyki w naukach ścisłych będących z natury naukami empirycznymi? Jeszcze dziś można usłyszeć dziewiętnastowieczny pogląd, iż teorie nauk ścisłych to odpowiednio zinterpretowane teorie matematyczne, którym w matematyce „czystej” żadnej interpretacji nie przypisywano. Głoszący ten pogląd powołują się z reguły na przykład geometrii (euklidesowej lub jakiejś nieeuklidesowej) jako teorii przestrzeni fizycznej. Tym samym zakładają oni, że punkty, linie, płaszczyzny i bryły, o których geometria ta mówi, są przedmiotami fizycznymi, które spełniają wszystkie założenia teorii. Jednakże w świetle teorii względności nie jest to możliwe; przestrzeń fizyczna jest zbyt ,pokrzywiona” pod wpływem rozmieszczonych w niej mas, aby mogła spełniać założenia jakiejś ,eleganckiej” geometrii inaczej, jak tylko lokalnie i z pewnym przybliżeniem. Wspomniany tu pogląd tym bardziej nie stosuje się do innych klasycznych teorii matematycznych takich jak arytmetyka lub analiza; żadne twierdzenie tych teorii nie staje się po odpowiedniej interpretacji czy reinterpretacji twierdzeniem fizyki. Kiedy w fizyce - co rzeczywiście ma miejsce - korzysta się z tych twierdzeń, zachowują one swój zwykły, matematyczny sens.

Korzystanie z matematyki w naukach ścisłych ma w istocie dwa aspekty. Pierwszy polega na zastosowaniu gotowego już, a przy tym bardzo ścisłego języka matematyki, dysponującego przystosowaną do operacji rachunkowych i w dużym stopniu ,standaryzowaną" symboliką. Aspekt drugi zasadza się na wykorzystaniu twierdzeń matematycznych jako przesłanek przy wyprowadzaniu wniosków. Jedno i drugie nie byłoby możliwe, gdyby nie to, że pomiar dostarcza reprezentacji przedmiotów i zjawisk fizycznych w postaci odpowiednich liczb i konstruktów liczbowych. Formuły matematyczne, którymi posługuje się fizyka nie mówią więc wprost o obiektach fizycznych, lecz o reprezentujących je obiektach matematycznych. Owe formuły, to zazwyczaj różnego rodzaju równania.

\footnotetext{
${ }^{5}$ Biel to klasyczny przykład cechy jakościowej, natomiast relacja, która zachodzi między przedmiotami wtedy i tylko wtedy, gdy bądź oba są białe, bądź oba niebiałe jest równoważnością, a zatem podział przedmiotów na białe i niebiałe jest wielkością.

${ }^{6}$ Długość, podobnie jak masa, to przykłady wielkości zaliczanych do ekstensywnych, ale nie jest tak, iż wszystkie wielkości fizyczne są ekstensywne. Na przykład temperatura nie jest wielkością ekstensywną.
} 
Z punktu widzenia fizyka, a zwłaszcza fizyka-teoretyka, stanowią one podstawowy składnik teorii fizycznych. Stąd często mówi się o teorii fizycznej tak, jak gdyby był to po prostu określony układ równań (np. klasyczną elektrodynamikę utożsamia się z czterema równaniami Maxwella), a pojedyncze równania nazywa się prawami fizyki. Praktyka ta, będąca w istocie skrótowym sposobem mówienia, jest zrozumiała, zważywszy, że praca fizyka-teoretyka polega głównie na wynajdywaniu odpowiednich równań i poszukiwaniu ich rozwiązań, zaś praca fizyka-doświadczalnika — na konfrontacji tychże rozwiązań z wynikami pomiarów. Jednakże - na co zwróciliśmy już uwagę w wykładzie czwartym - formuły zwane zazwyczaj prawami fizyki nie są tymi twierdzeniami, które fizycy skłonni byliby akceptować jako ściśle prawdziwe (w świetle znanych faktów) bez dodatkowych założeń i komentarzy. Droga od formuły matematycznej do twierdzenia mówiącego wprost o obiektach fizycznych jest długa i skomplikowana, nawet w przypadku prostych równań mechaniki klasycznej. Prześledźmy ją na przykładzie drugiej zasady dynamiki Newtona.

Zasada ta w starannym sformułowaniu ma postać równania:

$$
m_{i} \ddot{s}_{i}(t)=\sum_{k=1}^{n} \mathbf{f}_{i k}(t)
$$

w którym większość symboli to zmienne reprezentujące (na mocy niepisanej umowy) co następuje:

$n$ - pewną liczbę naturalną,

$i, k$ - dowolne liczby z przedziału $I=\{1, \ldots, n\}$,

$m$ - funkcję przyporządkowującą dowolnej liczbie z przedziału $I$ liczbę rzeczywistą dodatnią,

$t$ - dowolne liczby rzeczywiste, zapewne z ustalonego przedziału $T$,

$s$ - funkcję, która dowolnej liczbie $i \in I$ oraz $t \in T$ przyporządkowuje trójkę liczb rzeczywistych;

$f$ - funkcję, która parze liczb $i, k \in I$ oraz liczbie $t \in T$ przyporządkowuje trójkę liczb rzeczywistych.

Przy takiej interpretacji równanie (R) pozbawione jest wszelkiej treści fizycznej. Oczywiście, każdy, kto miał choć trochę do czynienia z fizyką, skłonny jest odczytywać je inaczej, na przykład tak:

(R') Masa ciała pomnożona przez jego przyspieszenie jest równa sumie sił działających na to ciało,

lub dokładniej:

(R”) W układzie złożonym ze skończonej liczby ciał, w każdym momencie t masa danego ciała pomnożona przez wartość, która $w$ momencie t przyjmuje druga pochodna z jego położenia względem czasu, jest równa sumie oddziaływań wywieranych na to ciało $w$ momencie $t$ ze strony ciat pozostałych. 
Zauważmy, że (R"), a tym bardziej (R') nie stanowią bezpośredniej interpretacji równania (R). Masa, położenie, czas i oddziaływanie, o których mowa w (R"), to wielkości fizyczne, natomiast funkcje $m, s$ i $f$ - to skale tych wielkości przy założeniu, że liczby $1, \ldots, n$ są ,numerami” reprezentującymi ciała, że dany jest pewien układ odniesienia, w którym $s_{i}$ określa trzy współrzędne ciała z numerem $i$ ze względu na $t$, które jest liczbą daną przez wskazanie jakiegoś zegara (według pewnej skali czasu) itp. W równaniu (R) musi być mowa o skalach, a nie o wielkościach, ponieważ na wielkościach nie można wykonywać takich operacji matematycznych o jakich mowa w równaniu $(\mathrm{R})^{7}$.

Aby równanie (R) „mówiło” to, co fizyk faktycznie chce nam zakomunikować o rzeczywistości fizycznej, musimy jeszcze dodać, że skale, o których tu mowa posługują się tym samym układem jednostek (np. CGS), że układ jest izolowany od oddziaływań ze strony ciał nie należących do układu, że położenie mierzymy względem układu inercjalnego, że ciała mają rozmiary znikome w porównaniu z odległościami między nimi albo są sztywnymi kulami o jednorodnej gęstości. Jeśli bierzemy pod uwagę efekty relatywistyczne, powinniśmy poczynić dalsze założenia.

Wszystko, co tu zostało powiedziane, to rzeczy banalne, które powinny nam wyjaśnić, dlaczego fizyk — w przeciwieństwie do matematyka ${ }^{8}$ — na ogół nie stara się zawrzeć w jednym twierdzeniu tego, co ma do powiedzenia. Okoliczność ta narzuca pewien obraz fizyki jako dyscypliny, której rola polega na tworzeniu modeli matematycznych pewnych zjawisk przyrodniczych. Model taki jest tylko narzędziem poznania rzeczywistości; wiedzę o niej możemy uzyskać, wyznaczając klasę zjawisk, do których model taki „stosuje się”, co zazwyczaj oznacza, że pozwala on odpowiednie zjawiska wyjaśniać, przewidywać $\mathrm{i}$ - w razie potrzeby - wywoływać lub im zapobiegać. Taki przewidywany lub postulowany zakres adekwatnych zastosowań danego modelu powinien być opisany w sposób od niego niezależny, a adekwatność polega tu na ogół na tym, że model stosuje się z „zadowalającym przybliżeniem”, co może oznaczać różne stopnie przybliżenia w zależności od zagadnienia, które rozwiązać zamierzamy.

Nakreślony powyżej obraz fizyki kłóci się z jej tradycyjnym wizerunkiem jako nauki odkrywającej ,,prawa przyrody” obowiązujące „,zawsze i wszędzie”. Jeśli fizyka dostarcza jedynie modeli, których zakres stosowalności nie daje się precyzyjnie scharakteryzować, to nie może dostarczyć twierdzeń ogólnych, które dotyczyłyby „,rzeczywistości fizycznej”. Wszelkie twierdzenia ściśle ogólne traktują wówczas o modelach matematycznych i jako takie są twierdzeniami matematyki, nie fizyki. Tym samym nie można mówić, że doświadczenie „obaliło” jakąś teorię fizyczną. Doświadczenie może jedynie wykazać, że pewien model w danym konkretnym przypadku nie stosuje się z pożądaną dokładnością, a zatem zakres jego adekwatnych zastosowań jest węższy niż oczekiwano. Może to skłaniać do poszukiwania modeli o szerszym zakresie zastosowań, ale nie dyskwalifikuje całkowicie poprzednich.

\footnotetext{
${ }^{7}$ Wprawdzie w potocznym żargonie fizyków mówi się, że prędkość to „pochodna z drogi po czasie”, ale wiadomo, że nie chodzi tu o drogę, tylko o funkcje o argumentach i wartościach liczbowych reprezentujące ruch obiektu.

8 Ale również biologa, mineraloga itp.
} 
Taki pogląd na fizykę jest podzielany przez wielu fizyków ${ }^{9}$, ale nie jest bezsporny. Być może jest on słuszny w odniesieniu do pewnych działów fizyki, lecz nie do wszystkich, jak również nie do wszystkich pozostałych nauk ścisłych. Dlatego charakteryzując ogólnie nauki ścisłe, nie będziemy go generalizować. Przyjmiemy natomiast, że do nauk ścisłych należa te dyscypliny naukowe, które, podobnie jak fizyka, $w$ szerokim zakresie stosuja pomiar $i$ w równie szerokim zakresie korzystaja z pojęć $i$ twierdzeń matematyki jako wyposażenia pomocniczego. Nie przesądzamy tu, czy korzystanie z matematyki polega na konstruowaniu modeli, czy po prostu na posługiwaniu się twierdzeniami matematycznymi jako przesłankami w rozumowaniu. Mówiąc o korzystaniu z matematyki jako wyposażenia pomocniczego, chcemy zaznaczyć, że obiekty matematyczne, o których mowa w naukach ścisłych, pełnią tu rolę narzędzia, a nie przedmiotu badań. Tym samym zakładamy, że terminy i formuły matematyczne zachowują tu swoje zwykłe znaczenie, które im przypisano w „matematyce czystej”. Określenie „w szerokim zakresie” odnoszące się do korzystania z matematyki sprawia, że pojęcie nauki ścisłej jest nieostre. Sądzimy, że takie pozostać powinno, ponieważ wytyczanie tu wyraźnych granic byłoby trudne, a ponadto nieuchronnie arbitralne.

\footnotetext{
${ }^{9}$ Na przykład w cytowanej już wcześniej książce W. Ko p i c z y ń s k i e g o i A. Tr a u t m a n a, $C z a-$ soprzestrzeń $i$ grawitacja (PWN, Warszawa 1981) czytamy: „Fizycy niemal z reguły pomijają milczeniem to, że wiele uwagi w swej działalności poświęcają modelom. Zwykle powiada się: rozpatrzmy atom wodoru według mechaniki kwantowej, sugerując w ten sposób, iż rzeczywiście rozpatruje się atom wodoru. W istocie jest tak, że zajmujemy się modelem matematycznym atomu wodoru proponowanym przez mechanikę kwantową. Dlaczego nikt nie mówi w ten sposób? Po pierwsze dlatego, że obywanie się bez zwrotu «model matematyczny» jest wygodne, a chociaż jest nieścisłe, nie prowadzi na ogół do pomyłek. Po drugie, przyjemniej jest robić sobie złudzenia, że zajmujemy się bezpośrednio obiektywną rzeczywistością, a nie tylko jej matematycznymi modelami. Fizycy, oczywiście, mają jak najlepsze chęci i chcą mówić o tej rzeczywistości, ale jedyną rozsądną drogą jest tu, jak się wydaje, budowanie modeli”.

„Czasami czyta się lub słyszy, że ktoś obalił jakąś teorię, że np. Einstein obalił teorię Newtona. Jeśli zgodzić się, że główną treścią teorii fizycznych są modele, które w przybliżony sposób opisują rzeczywistość, to twierdzenie powyższe nie ma wielkiego sensu. W najlepszym razie można podać modele, które będą lepiej opisywać zjawiska niż modele dotychczasowe; tak właśnie zdarzyło się z teorią Einsteina” (s. 28-29).

„Zdarza się czasami, że są dwa konkurencyjne modele, które mają ambicję opisywać ten sam krąg zjawisk, w tym samym przybliżeniu, i okazuje się, że jeden z tych modeli daje wyniki zgodne z obserwacjami, drugi zaś nie. [...] Znacznie częściej sytuacja jest taka, że mamy szereg modeli, które opisują rzeczywistość w pewnym zakresie zjawisk, lecz każdy w nieco innym. Wtedy możemy starać się o ulepszenie tych modeli, tzn. zastąpienie ich takimi, które mają szerszy zakres stosowalności” (s. 30).
} 